\title{
INFLUÊNCIA DE CINCO PORTA-ENXERTOS NA INTENSIDADE DE "STEM PITTING" DE TRISTEZA, NO VIGOR E NA PRODUTIVIDADE DA LARANJEIRA 'WESTIN', Qitrus sinensis (L.) OSBECK
}

FRANCISCO JOSÉ SALCEDO CEDEÑO

Orientador: Prof. CÉLIO SOARES MOREIRA

Dissertação apresentada à Escola Superior de Agricultura "Luiz de Queiroz", da Universidade de São Paulo, para obtenção do título de Mestre em Agronomia. Área de Concentração: Fitotecnia.

PIRACICABA

Estado de São Paulo - Brasil

Maio - 1984 
ii.

A Moraima,

Aos meus filhos, Aos meus pais,

A Esther,

A amizade dos colegas

brasileiros, DEDICO. 
.iii.

Homenagem

Ao Fondo Nacional de Investigaciones Agropecuärias de venezuela, especial mente ao Campo Exp. Caripe, pelo engrandecimento da agricultura venezue lana e à carreira científica. 


\section{AGRADECIMENTOS}

- Ao Prof. Dr. Célio Soares Moreira, pela or $\underline{i}$ entação, dedicação e grande estímulo na execução e preparo deste trabalho.

- Ao Prof. Dr. Ary A, Salibe, pela colaboração, apoio e permanente estimulo.

- Ao Fondo Nacional de Investigaciones Agrope cuárias de Venezuela, pela oportunidade, facilidade e financiamento oferecidos para a realização do curso.

- As Professoras Dra. Marinéia de Lara Haddad, da Empresa Brasileira de Pesquisa Agropecuāria pelo auxilio nas anälises estatisticas e Dra. Marta Maria Mischam, UNESP-Botucatu, pela orientação recebida.

- Ao Enge Agro José Menechino Junior pelas su gestões, colaboração e sincera amizade.

- Aos Colegas pós-graduandos pela amizade, apoio e convivio inesquesciveis fornecido durante o curso.

- Aos Funcionärios do Departamento de Horticultura da ESALQ-USP pela amizade e auxilios prestados, especialmente ao Sr. Aparecido Mendes e Sr. Benedito Thomé Franco do Dpto. de Horticultura da FCA-UNESP-Campus de Botucatu. 
$\cdot v$.

Queiroz", da Universidade de São Paulo, que possibilitou a realização desta pesquisa.

- A todos que de alguma forma contribuiram pa ra a realizaço deste trabalho, especialmente ao pessoal da Biblioteca Central, ESALQ-USP.

- A Sónia Novaes Rasera, pelos servicos de da tilografia. 
.vi.

\title{
INDICE
}

\begin{abstract}
pägina

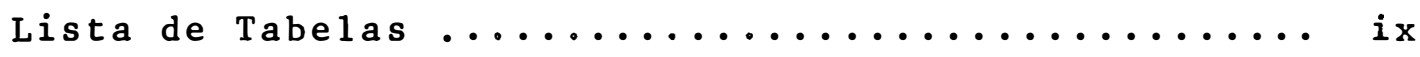

Lista de Figuras $\ldots \ldots \ldots \ldots \ldots \ldots \ldots \ldots \ldots \ldots \ldots$

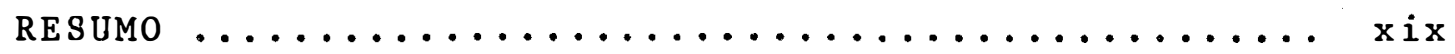

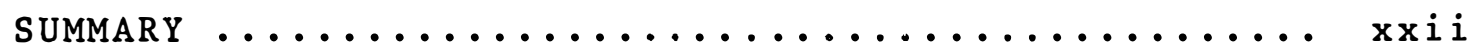

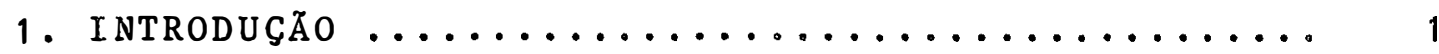

2. REVISÃo de literatura ................... 6

2.1. A Tristeza dos citros ................. 6

2.1.1. Nome e sinōnimos da doença ........ 6

2.1.2. Histórico e distribuição geogräfica. 8

2.1 .3$. Etiologia .................... 9

2.1.4. Raças ou estirpes do virus da Triste-

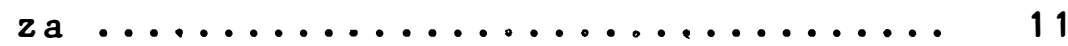

2.1.5. Sintomatologia ................. 13

2.1.6. Reação de tipos de citros ......... 16

2.2. Método de indexação da doença ............ 19

2.3. o uso do porta-enxerto como controle da doen

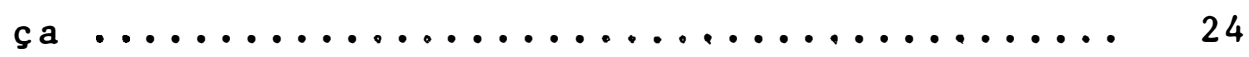

3. MATERIAL E METODOS ........................ 27

3.1. Pomar experimenta1 ................. 27

3.1 .1 . Variedade enxerto .............. 27

3.1.2. Variedades porta-enxertos ......... 29

3.1.3. Localização do pomar experimental ... 31

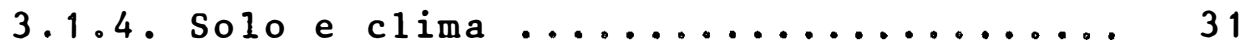

3.1.5. Plantio do pomar e instalação do expe rimento $\ldots \ldots \ldots \ldots \ldots \ldots \ldots \ldots \ldots \ldots \ldots \ldots \ldots \ldots \ldots$ 
. vie.

$\underline{\text { pàgina }}$

3.1.6. Delineamento experimental ........ 32

3.1 .7$. Tratos culturais .............. 33

3.1 .8 . Mensurações ................. 33

3.1.9. Avaliação de "stem pitting" ou caneluras em ramos das laranjeiras 'Westin'. 36

3.2. Viveiro experimental para indexação do virus. 37

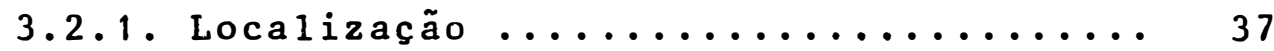

3.2 .2 . Clima da região .............. 38

3.2.3. Obtenção de plantas testes de 1 imão Ga lego, Citrus aurantifolia swingle .... 38

3.2.4. Mètodo de indéxação do virus ....... 39

3.2.5. Avaliação dos sintomas foliares e

"stem pitting" ou caneluras nas plan-

tas teste de 1 imão Galego .......... 40

3.2.6. Delineamento estatístico ......... 42

3.3. Anālise estatistica .................... 42

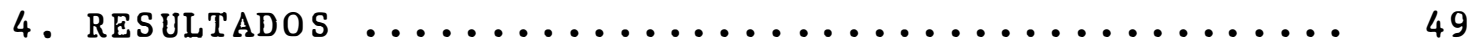

4.1. Avaliação de sintomas de Tristeza em plantas

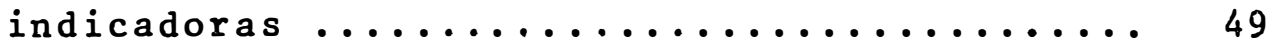

4.1.1. Avaliação de sintomas em plantasiteste 49

4.1.2. Anälise estatistica dos resultados ... 49

4.2. Avaliação de "stem pitting" na laranjeira 'Wes

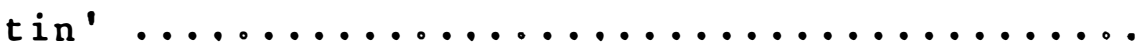

4.2.1. Avaliação de "stem pitting" ou caneluras $\ldots \ldots \ldots \ldots \ldots \ldots \ldots \ldots \ldots \ldots \ldots$ 
.viii.

pàgina

4.3. Vigor das plantas .................. 60

4.3.1. Dados dos parâmetros físicos do vigor. 60

4.3.2. Anālise estatistica dos resultados ... 60

4.4. Produção ........................... 69

4.4.1. Dados de produção .............. 69

4.4.2. Anàlise estatistica dos resultados ... 69

4.5. Seleção de grupos afins das combinaçóes laranja 'Westin' sobre porta-enxertos ...... 78

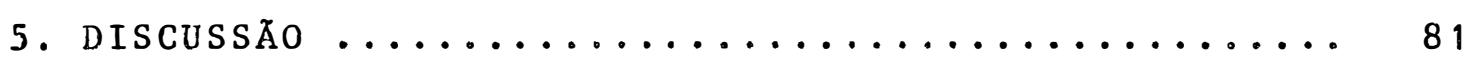

5.1. Avaliação de sintomas em plantas indicadoras. 81

5.2. Avaliação de "stem pitting" na laranjeira

'Westin' ........................ 83

5.3. Vigor das plantas $\ldots \ldots \ldots \ldots \ldots \ldots \ldots \ldots . \ldots 6$

5.4 . Produção .......................... 90

5.5. Seleção de grupos afins de porta-enxertos ... 93

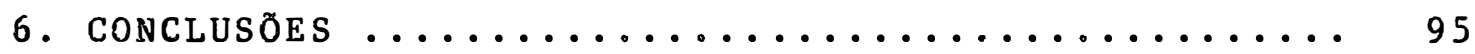

7. Literatura citada $\ldots \ldots \ldots \ldots \ldots \ldots \ldots \ldots \ldots \ldots . \ldots \ldots$

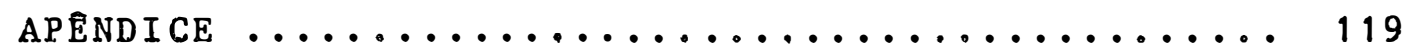




\section{LISTA DE TABELAS}

Tabe 1a

pägina

1. Anàlise da variāncia das notas médias dos tes tes de Tristeza em plantas de limão Galego utilizando diferentes inöculos, provenientes de plantas de laranjeira 'Westin' sobre cinco porta-enxertos. ESALQ-USP, Piracicaba, SP. Feve-

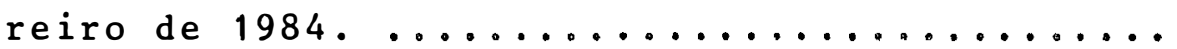

2. Comparação entre notas médias da avaliação de sintomas de Tristeza, em plantas teste de 1 imão Galego, da laranjeira 'Westin' sobre cinco porta-enxertos. ESALQ-USP, Piracicaba. Fevereiro de 1984 .

3. Coeficiente de correlação ( $r$ ) e equações de regressão simples entre os parametros de "stem pitting" de planta teste e "stem pitting" em ra mos e diàmetro da copa, altura da planta e produção (kg/parcela), da laranjeira 'Westin' sobre cinco porta-enxertos. ESALQ-USP, Piracicaba, SP. Fevereiro de 1984...............

4. Coeficientes de correlação simples para os para metros sintomas "stem pitting" e sintomas em fo 1has em plantas teste de 1 imão Galego, "stem pitting" em ramos e altura da planta, diámetro da copa e produção (1969-74), da laranjeira'Westin' sobre cinco porta-enxertos. ESALQ-USP, Pi- 
racicaba, SP. Fevereiro de $1984 \ldots \ldots \ldots \ldots \ldots$

5. Anālise da variāncia dos dados mëdios referentes as notas dos testes de Tristeza em ramos de laranjeira 'Westin' sobre cinco porta-enxer tos. ESALQ-USP, Piracicaba, fevereiro de 1984.

6. Comparação entre médias de notas mëdias da ava 1 iação de sintomas de Tristeza em ramos da 1 aranjeira 'Westin' sobre cinco porta-enxertos. ESALQ-USP, Piracicaba, fevereiro de $1984 \ldots .$.

7. Significancia dos valores do Teste $F$ e para os parāmetros: circunferência do tronco, diàmetro da copa, altura da planta, área produtiva

e indice de conformação da laranjeira 'Westin' (Citrus sinensis osbeck) sobre cinco porta-enxertos. ESALQ-USP, Piracicaba, SP, Fevereiro

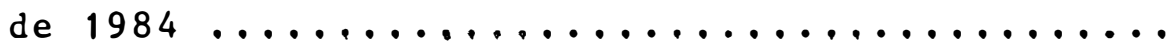

8. Comparação entre médias de porta-enxertos para os paràmetros do desenvolvimento em laranjei ras 'Westin' sobre cinco portarenxerto, ESALQ -USP, Piracicaba, Fevereiro de $1984 \ldots \ldots \ldots \ldots$....

9. Coeficiente de correlação (r) e equações de re gressão entre os parāmetros físicos do desenvolvimento e vigor da laranjeira 'Westin' sor 
bre cinco porta-enxertos, ESALQ-USP, Piracica ba, SP, fevereiro de $1984 \ldots \ldots \ldots \ldots \ldots \ldots$

10. Significāncia dos valores do teste f para os parāmetros: produção média (1969-74), produção em número de frutos/parcela (1980-82) e nümero de caixas/parcela (1980-82) da 1.aranjeira 'Westin' sobre cinco porta-enxertos . ESALQ-USP, Piracicaba, SP. Fevereiro de

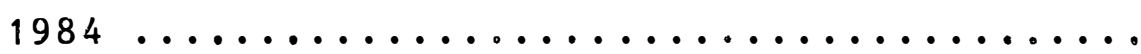

11. Comparação entre valorés médios dos parämetros da produção: kg/parcela no período de 1969 a 1974; nümero de frutos/parcela e nümero de caixas/parcela (1980-82) da laranjeira 'Westin' so bre cinco porta-enxertos. ESALQ-USP, Piracicaba, SP. Fevereiro de $1984 \ldots \ldots \ldots \ldots \ldots \ldots$

12. Coeficiente de correlação ( $r$ ) e equações de regressão simples entre o paràmetro produção em caixas de frutos/parcela e os diferentes parame tros estudados, na laranjeira 'Westin' : sobre cinco porta-enxertos. ESALQ-USP, Piracicaba, SP. Fevereiro, 1984. ....................

13. Principais caracteristicas quimicas do solo da

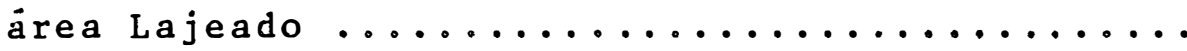


14. Totais de precipitação pluviométrica (mm) e mëdia de temperatura mensal $\left({ }^{\circ} \mathrm{C}\right)$, ocorridos nos pe ríodos de junho a dezembro de 1982 e janeiro a dezembro de 1983, na ārea de Lajeado, UNESP/Botucatu. sp. $\ldots \ldots \ldots \ldots \ldots \ldots \ldots \ldots$

15. Delineamento experimental na ärea de Lajeado, Est. Exp. Presidente Médici, UNESP, Botucatu, SP

16́. Totais de precipitação pluviométrica (mm) e média de temperatura mensal $\left({ }^{\circ} \mathrm{C}\right)$ ocorridos nos pe ríodos de junho a dezembro de 1982 e janeiro a dezembro de 1983, na ärea da ESALQ-USP, Piraci-

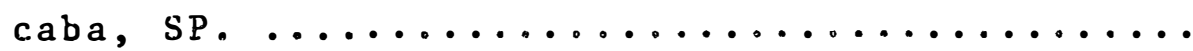

17. Delineamento do viveiro experimental de 1 imoeiro Galego (Citrus aurantifolia Swingle) para in dexaçäo do virus da Tristeza em copas de laranjeira 'Westin' sobre cinco porta-enxertos.ESALQ -USP, Piracicaba, SP. Julho de 1982. .......

18. Leitura de "stem pitting" ou caneluras em plantas teste de Limão Galego, no viveiro experimental da ESALQ-USP, Piracicaba, SP, em 1984.....

19. Leitura média de sintomas em folhas das plantas teste de Limão Galego, na ESALQ-USP, Piracicaba,

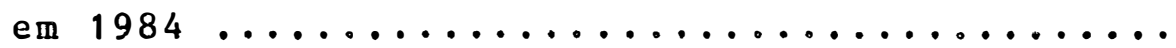


20. Leitura de "stem pitting" ou caneluras em ramos da copa das laranjeiras 'Westin', na E.E. Presi dente Médici - UNESP, Botucatu, SP, em 1984. .

21. Circunferência média (cm) do tronco da laranje ra'Westin', sobre os diferentes porta-enxertos na E.E. "Presidente Médici", Botucatu, SP, em

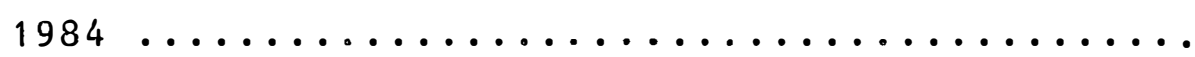

22. Diâmetro médio (m) da copa da laranjeira 'Westin', sobre os diferentes porta-enxertos, na E. E. "Presidente Médici", Botucatu, SP, em 1984..

23. Altura média (m) das plantas de laranjeira 'Wes tin' sobre os diferentes porta-enxertos, na E. E. "Presidente Mëdici" - UNE\&P, Botucatu, SP,

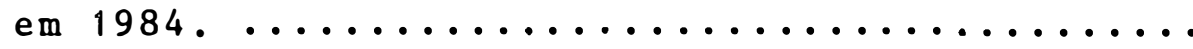

24. Årea produtiva média $\left(\mathrm{m}^{2}\right)$ da laranjeira 'Westin' sobre os diferentes porta-enxertos, em $1984 \ldots$..

25. Indice de conformação (A/D) das laranjeiras 'Wes tin' sobre os diferentes porta-enxertos ......

26. Produção média (1969-1974 em kg/parcela) da laranjeira 'Westin' sobre os diferentes porta-enxertos, na E.E. "Presidente Medici"- UNESP, Bot $\underline{u}$

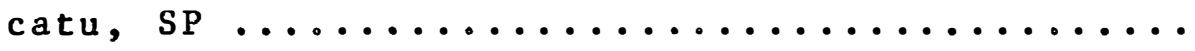


. $x i v$.

Tabe 1 a

$\underline{\text { pàgina }}$

27. Produção mëdia de 3 anos (1980-82), em nümero de caixas/parcela, das laranjeiras 'Westin' sobre os diferentes porta-enxertos, na E.E. "Presidente Mëdici" - UNESP, Botucatu, SP ....... 136

28. Produção médio de 3 anos (1980-82), em nümero de frutos/parcela, das laranjeiras 'Westin' sobre os diferentes porta-enxertos, na E.E. 'Presi dente Médici" - UNESP, Botucatu, SP ......... 


\section{LISTA DE FIGURAS}

Figura

pägina

1. Folhas de limoeiro Galego mostrando escala de notas em sintomas do virus da Tristeza, desde

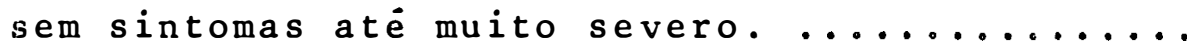

2. Folha de limoeiro Galego mostrando sintomas de palidez das nervuras (Tristeza), destacas de plantas inoculadas com borbulhas de laranjeira

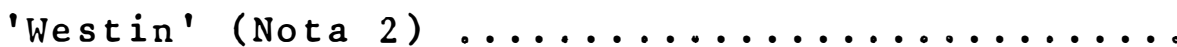

3. Ramos de 1 imoeiro Galego mostrando sintomas do virus da Tristeza de amarelecimento (Nota 3), destacado da planta teste inoculada com gemas da copa da laranjeira 'Westin'; lado esquerdo

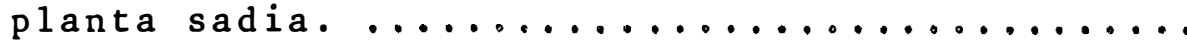

4. A esquerda ramo de 1 imoeiro Galego mostrando sin tomas do virus da Tristeza de "folhas pequenas e curvas para a face superior" (Nota 4), destacado da planta teste inoculada com gemas de copa da laran jeira 'Westin'; a direita ramos da planta sadia.

5. A direita, ramo de limoeiro Galego mostrando sintomas de suberificação das nervuras (Tristeza), a direita ramos de plantas sadias .......

6. Folha de 1 imoeiro Galego mostrando sintomas de suberificação das nervuras (Tristeza dos ci- 
tros), destacadas de plantas inoculadas com bor bulhas de laranjeira 'Westin' (Nota 5 ) ........ 48

7. Equação de regressão entre o "stem pitting" :em ramos e altura da planta da laranjeira 'Westin' sobre cinco porta-enxertos. ESALQ-USP, Piracicaba, SP. Fevereiro, $1984 \ldots \ldots \ldots \ldots \ldots \ldots$

8. Equação de regressão entre o "stem pitting" em ramos e produção de frutos em kg/parcela (1969-74) da laranjeira 'Westin' sobre cinco porta -enxertos. ESALQ-USP, Piracicaba, SP. Feverei

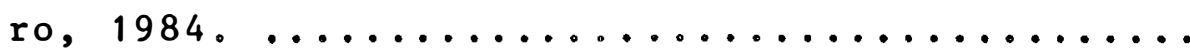

9. Equação de regressão entre a circunferencia do tronco ( $\mathrm{cm}$ ) e diâmetro da copa ( $\mathrm{cm}$ ) da laranje ra 'Westin' sobre cinco porta-enxertos. ESALQ-USP, Piracicaba, SP. Fevereiro, 1984. ......

10. Equação de regressão entre a circunferencia do tronco (cm) e altura de planta (m) da laranjeira 'Westin' sobre cinco porta-enxertos. ESALQ-USP, Piracicaba, SP. Fevereiro, $1984 \ldots \ldots \ldots$

11. Equação de regressão entre a circunferência do tronco (cm) e ärea produtiva $\left(\mathrm{m}^{2}\right)$ da lananjeira 'Westin' sobre cinco porta-enxertos. ESALQ-USP, Piracicaba, SP. Fevereiro, $1984 \ldots \ldots \ldots \ldots$. 
Figura

.xuie.

pàgina

12. Equação de regressão entre diâmetro da copa (cm) e ärea produtiva $\left(\mathrm{m}^{2}\right)$ da laranjeira 'Westin' sobre cinco porta-enxertos. ESALQ-USP,P racicaba, SP. Fevereiro, $1984 \ldots \ldots \ldots \ldots \ldots$

13. Equação de regressão entre o número de caixas de frutos/parcela e circunferēncia do tronco (m) na laranjeira 'Westin' sobre cinco porta-enxertos. ESALQ-USP, Piracicaba, SP. Feve-

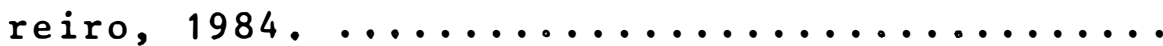

14. Equação de regresião entre o número de caixas de frutos/parcela e o diāmetro da copa na laranjeira 'Westin' sobre cinco porta-enxertos (cm). ESALQ-USP, Piracicaba, SP. Fevereiro,

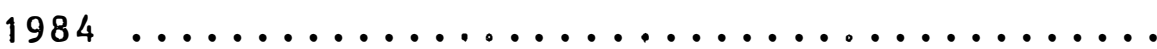

15. Equação de regressão entre o nümero de caixas de frutos/parcela e a altura da planta na 1aranjeira 'Westin' sobre cinco porta-enxertos. ESALQ-USP, Piracicaba. Fevereiro, $1984 \ldots \ldots$.

16. Equação de regressão entre o nümero de caixas de frutos/parcela a àrea produtiva da laranje ra 'Westin' sobre cinco porta-enxertos. ESALQ-USP, Piracicaba, SP, Fevereiro, $1984 \ldots \ldots \ldots$ 
-enxertos para a laranjeira 'Westin', em função dos sintomas de Tristeza ("stem pitting" em ramos e planta teste), vigor e produção, pelo método de anälise de componentes principais ....

18. Fenograma representativo de porta-enxertos afins para a laranjeira 'Westin'. determinados em fun ção dos parāmetros: sintomas de Tristeza ("stem pitting" em ramos e indexação em limão Galego), vigor e produção, da Anàlise de Agrupamento ...

19. Representação gräfica em barras de notas médias da avaliação de "steñ pitting" em ramos da laranjeira 'Westin' sobre cinco porta-enxertos. ESALQ-USP, Piracicaba, SP . Fevereiro, 1984 ...

20. Representação gräfica em barras das médias dos valores do desenvolvimento e vigor da laranjeira 'Westin' sobre cinco porta-enxertos. ESALQ-USP, Piracicaba . Fevereiro, $1984, \ldots \ldots \ldots \ldots$.....

21. Representação gräfica em barras dos valores dos parâmetros de produção da laranjeira 'Westin ' sobre cinco porta-enxertos, ESALQ-USP, Piracicaba, SP. Fevereiro, $1984 \ldots \ldots \ldots \ldots \ldots \ldots \ldots \ldots$ 


\section{INFLUENCIA DE CINCO PORTA-ENXERTOS NA INTENSIDADE DE "SteM PITTING" DE TRISTEZA, NO VIgOR E NA PRODUTIVIDADE DA LARANJEIRA 'WESTIN', Citrus sinensis ( $L$. ) Osbeck \\ Autor: FRANCISCO JOSE SALCEDO CEDENO \\ Orientador: Prof. CELIO SOARES MOREIRA}

\section{RESUMO}

Foi estudado neste trabalho a influência do porta-enxerto na expressão de sintomas de "stem pitting" de Tristeza, e os efeitos da sua presença no vigor e produção da laranjeira 'Westin', Citrus sinensis (L.) osbeck, de clone nucelar.

Com esse objetivo, o experimento foi conduzido em pomar experimental na Fazenda Lageado, UNESP/Botucatu, situado a $22^{\circ} 52^{\prime} 55^{\prime \prime}$ de latitude sul e $48^{\circ} 26^{\prime} 22^{\prime \prime}$ de longitude ocidental, a $830 \mathrm{~m}$ de altitude. Também, instalou-se um viveiro experimental de "seedlings" nucelares de limoeiro 'Galego' para indexação da doença, na ESALQ/USP, Piracicaba, SP, a $22^{\circ} 42^{\prime} 30^{\prime \prime}$ de latitude sul e $47^{\circ} 38^{\prime} 00^{\prime \prime}$ de longitude, a 586 m de altitude.

As plantas estudadas, com 18 anos de idade, tiveram como porta-enxertos: o 1 imoeiro cravo (Citrus limonia Osbeck), limoeiro Rugoso da Flórida (Citrus jambhiri Lush.), a 
tangerineira Sunki (Citrus sunki Hort ex Tanaka), o trifolia ta (Poncirus trifoliata Raf), e laranjeira Caipira (Citrus sinensis (L.) osbeck).

0 delineamento experimental foi em blocos ao acaso com 6 repetições e 5 tratamentos. Utilizou-se no po mar experimental 2 plantas por parcela e para o viveiro 4 plantas por parcela.

A severidade da raça presente foi determinada através da indexação em limoeiro Galego, tomando-se como base para a avaliação a intensidade dos sintomas em folhas e intensidade de "stem pitting" em ramos. Para a avaliação da incidéncia na copa da laranjeira, retirou-se 10 ramos novos das duas plantas de cada parcela. Cada ramo com cerca de 20 cm de comprimento foi descascado e avaliado quanto a presença de "stem pitting" segundo uma escala de notas de 0 a 5. Foram analisados dados de produção de frutos, no periodo de 1969-1974 e 1980-1982, expressados, respectivamente em quilogramas de frutos, e, nümero de caixas e nümero de frutos.

Realizou-se mensurações da circunferência do tronco, altura da planta, diāmetro de copa e indice de conformaça como indicativas do vigor, e a ärea produtiva.

Separou-se pelo método de Anālise de Componen tes Principais e Anälise de Agrupamento, os porta-enxertos em quatro grupos distintos, em função dos parámetros estudados, 
apresentando-se os resultados através do fenograma e através de representação gräfica tridimensional.

Detectou-se a presença de uma raça severa do virus da Tristeza. Observou-se variações na quantidade de "stem pitting" segundo o porta-enxerto utilizado. Copas de 'Westin' sobre o 1 imoeiro Cravo mostraram menores quantidades de "stem pitting", enquanto que as copas de 'Westin' sobre trifoliata mostraram as maiores quantidades. Houve alta correlação entre maior presença de "stem pitting" e menor produção. A produção das laranjeiras foi influenciada pelos diferentes porta-enxertos. Verificou-se a influencia do limoeiro Cravo na precocidade de produção da laranjeira 'Westin', enquanto que o porta-enxerto de laranjeira caipira retardou a produção. Os porta-enxertos laranjeira Caipira e tangerineira Sunki, que induziram o maior vigor, proporciona ram as maiores produções nas colheitas dos anos 1980 a 1982.

\section{A Anälise dos 'Componentes Principais e Análi-} se de Agrupamento determinaram a existência de 4 grupos dife rentes de portamenxertos: Grupo 1, Laranjeira Caipira; Grupo 2, Limoeiro Cravo e Tangerineira Sunki, Grupo 3, Limoeiro Rugoso da Florida e Grupo 4, trifoliata. Constatou-se a importância do estudo da circunferência do tronco, presença de "stem pitting" e produção da planta na seleção dos grupos descritos acima. 


\title{
INFLUENCE OF FIVE ROOSTOCKS ON THE TRISTEZA STEM
}

PITTING INTENSITY, ON THE VIGOR AND ON THE PRODUCTIVITY OF

'WESTIN' ORANGE, Citrus sinensis ( $L$.) osbeck

\author{
Author: FRANCISCO JOSE SALCEDO CEDEÑO \\ Adviser: Prof. CELIO SOARES MOREIRA
}

\section{SUMMARY}

This research was carried out to study the rootstock influence on the Tristeza Stem Pitting symptoms expression, and its relation with the vigor and the productivi ty of trees of one nucellar clone of 'Westin' orange, $C i$ trus sinensis (L.) osbeck.

The trees were 18 years old and were budded on five different rootstocks: Rangpur lime (Citrus li monia osbeck), Florida-rough-lemon (Citrus jambhiri Lush), Sunky mandarin (Citrus sunki Hort ex Tanaka), trifoliate orange (Poncirus trifoliata Raf) and Caipira sweet orange (Citrus sinensis (L.) osbeck).

The experimental orchard was located in Lageado Farm, of UNESP/Botucatu city, São Paulo State (Brazil), which coordenates are $22^{\circ} 52^{\prime} 55^{\prime \prime}$ South and $48^{\circ} 26^{\prime} 22^{\prime \prime}$ West Greenwich, at 830 meters above the sea level. A nursery for indexing Citrus Tristeza Virus with nucellar 
seedlings of West Indian lime, was established at ESALQ-USP, in Piracicaba city, São Paulo State (Brazil), which coordenates are $22^{\circ} 42^{\prime} 30^{\prime \prime}$ South and $47^{\circ} 38^{\prime} 00^{\prime \prime}$ West, at 586 meters above the sea level.

The experimental design was randomized complete blocks, with six replications and five treatments. There were two-tree plots in the experimental orchard, and four-tree plots in the experimental nursery for index test.

The severity of the strain of Citrus Tristeza Virus was determinated by using West Indian lime for indexing. The results were based on the intensity of the stem pitting symptoms on leaves and branches.

In order to evaluate its incidence in the sweet orange canopy, samples consisting in ten young branches, $20 \mathrm{~cm}$ long, of each two plants per plot were collected. Each branches had its bark removed and its amount of stem pitting was rated from zero to five.

The orange production was avaliated in the periods of 1969-1974 and 1980-1982, bu kilograms of fruit per tree, and by bruit-pack and number of fruits per tree, respectively. 
The trunk circunference, height and width of the canopy and the conformation-index, were taken as indicatives of tree vigor. The productive area of tree canopy, had been determinated.

The results showed severe strains of Citrus Tristeza Virus in the trees. The amount of pitting was significantly affected by different rootstocks. Trees budcied, on Rangpur-1ime rootstocks were found to be 1 ight pitted, while those on trifoliate rootstock were found having higher amount of stem pitting. There were high correlation between the higher amount of stem pitting and the poor production.

The production of the orange tree was clearly influenced by rootstocks. The trees on Rangpur 1 ime were earlier to come into bearing, while those on Caipira sweet orange were delayed in bearing large yields.

The rootstocks, Caipira sweet orange and Sunky mandarin, that induced a larger tree vigor, also provided greater production in the 1y8u-1982 period.

\section{Using the Analysis of Primary Components} Method and Agrupament Analysis four different groups of citrus rootstocks were determined, based on the studied parameters: Group 1, Caipira sweet orange; Group 2, Rangpur-1ime and Sunki mandarin; Group 3, Florida-rough-lemon and Group 4, Trifoliate orange. It was reported the importance 
of trunk circunference, study the Tristeza stem pitting expression and the production of tree in separating these three groups. 


\section{INIRODUCAO}

Atualmente, o Brasil é o segundo maior produtor de citros do mundo e o maior exportador de suć concentrado congelado. No ano de 1982 o pais exportou 521.217 toneladas de suco concentrado de laranjas a um preço médio de $1.100 \mathrm{U} \$ / \mathrm{t}$. As frutas citricas são produzidas em todas as unidades da federação, destacando-se por volumes mais expres sivos os Estados de São Paulo, Sergipe, Rio dé Janeiro, Rio Grande do Sul, Minas Gerais e Bahia, sendo São, Paulo hoje o maior produtor mundial de laranjas (sendo seguido pelo Estado norte-americano da Flörida), com 461 mil hectares plantados com laranjeiras que produzem 181 milhões de caixas de frutas. A produçãó total de citros do Estado estä calculada em 207 milhões de caixas, sendo que a de laranja representa cerca de $80 \%$ da safra brasileira. E o Estado abastecedor de suco concentrado, de seu mercado e dos mercados de diversos outros Estados do País. Porém pouco suco concentrado é ven- 
dido dentro do pais, que apenas consome cerca de $4 \%$ da sua produção.

A cultura das plantas citricas que, atualmente constitui um campo importante de exploração agricola, embora esteja atravessando uma fase economica excelente e mesmo promissora, esta sujeita a um grande nümero de doenças que, no seu conjunto, se tornam um fator limitante da cultura emà̃ias partes do globo.

A virose, Tristeza-dos-citros constitui, sem dúvida um dos problemas de doenças mais graves da cultura dos citros no mundo, e nenhuma das regiões onde foi relatada, a doença apresentou-se com a importāncia que teve e ainda tem para o Brasil.

SALIBE (1973), considera que para a década dos anos 70 o número total de plantas de citros existente no mundo era ao redor de 450 milhões de plantas. Pode ser esti mado que perto dos $50 \%$ delas são portadoras, de virus da tristeza. Aproximadamente a metade das plantas, quase 100 milhões, eram enxertadas com porta-enxertos intolerantes ao virus da Tristeza, principalmente laranja azeda.

Após o evento da "Tristeza" no fim da década de trinta,a utilização de porta-enxertos tolerantes a essa moléstia, e a obtenção de clones nucelares livres de outras viroses, possibilitaram, a partir da década de sessenta,ores surgimento da citricultura paulista. Porém, sendo o virus 
da "Tristeza" transmitido pelo "pulgão preto" (Toxoptera citricidus Kirk.), que è endēmico no Brasil e praticamente impossivel de ser exterminado, tal fato, obriga as plantas citricas a conviverem com esse virus.

E assim, como nessas regiões nas quais tem si do considerado como um virus endémico, as perdas causadas por "stem pitting" ou caneluras de Tristeza, embora utilizando portamenxertos tolerantes, tem ocasionado os mais sérios problemas.

o que inicialmente foi considerado um problema de sintoma limitado a pomelos, limas äcidas e alguns outros tipos de citrus, tornou-se de grande importância a partirdos anos 60 indicando a presença do virus na principal va riedade comercial de laranjeira doce do país, como é a laran jeira Pera. Atualmente, segundo SALIBE (1977) a sua presenca em muitas outras variedades comerciais de l'aranjeiras doces tem feito com que as injurias e consequentes perdas economicas devido ao "stem pitting" de Tristeza, nas äreas onde é endêmico, sejam maiores que as destruições causadas pelo virus nas plantas enxertadas sobre os porta-enxertos intolerantes, nessas mesmas-ärcas. A utilização de porta-enxerto tolerante, logo soluciona os problemas da Tristeza, porém o "stem pitting" inicia-se incrementando-se como problema permanente nessas äreas. 
riedades-usadas como copa devem ser testadas na sua reação ao "stem pitting" de Tristeza, no caso da variedade ser recomendada nas äreas infectadas com o virus; portanto pesquisas devem ser feitas em todas as regiões onde a sua presença seja detectada visando a se obter variedades tolerantes.

$$
\text { Por outra parte, ao ser a cultura de citros }
$$

propagada, quase que exclusivamente por reprodução assexuada ou enxertia, na formação da muda comercial de citros, existe a possibilidade de interação entre o virus da borbulha e o que pode existir no porta-enxerto. Isso é baseado no conhecimento de que a maioria das gemas das variedades de citros utilizadas na propagação são portadoras do virus da Tristeza e pelo fato de que porta-enxertos de citros em viveiros comerciais do Estado de São Paulo podem ou não estar infectados pelo vírus da Tristeza, por ocasião da enxertía.. Tudo devido a ação do inseto vetor do virus, o pulgão preto (Toxoptera citriciduskirk.). Em qualquer dos casos, os estudos de intera ção entre o virus da borbulha e o porta-enxerțo são de bastante interesse, sendo de particular importāncia para variedades intolerantes ao virus.

Nesta pesquisa, utilizando a laranjeira 'Westin' como copa enxertada sobre cinco diferentes porta-enxertos, com dezoito anos de idade, visou-se estudar a influência dos porta-enxertos na expressão de sintomas de "stem pit ting" de Tristeza na variedade copa e os possiveis efeitos da presença do "stem pitting" no vigor e produtividade no 
.5 .

conjunto porta-enxerto e copa. Objetivou-se, assim, obter informações que pudessem selecionar os porta-enxertos estuda dos em grupos de resposta comuns as interaçós copa-cavalo-virus, visando a incrementar o conhecimento e aplicabilida de dos resultados das reaçós dos diferentes citros evidenciados pela presença do "step pitting" de Tristeza dos citros. 


\section{REVISAO DE LITERATURA}

\subsection{A Tristeza dos citros}

2.1.1. Nome e sinônimos da doença

Inicialmente foi reconhecida na Arica do Sul e atribuida a problemas de "incompatibilidade" das combinações de laranja doce [Citrus sinensis (L.) osbeck), tangerinas (C. reticulata Blanco) e pomelos (C. paradisi Macf.) enxertados em laranja azèda (C.aurantium L.) (BENETT e COSTA, 1949).

TOXOPEUS (1937), em Java, comparou a similitü de dos sintomas nas mesmas combinações de citros que ocorreram na Africa do Sul, reconfirmando a "incompatibilidade" apresentada entre combinações de certos citros.

Recebeu o nome de "podedumbre de las raicillas de los citricos" na Argentina em 1930 ou 1931, pela desorganização e decomposição das raizes das plantas infecta 
das (ZEMAN, 1931 e CARRERA, 1933).

Descoberta no Brasil, no Vale do Paraiba por BITANCOURT em 1937, foi inicialmente denominada "a doença dos citros no Vale do Paraiba", sendo posteriormente batizada por MOREIRA (1942), como Tristeza dos citros ou simplesmente Tristeza; nome reconhecido a nivel mundial para a iden tificạ̧ão da doença.

Outras denominações com as quais foi assinala da são: "Quick decline", observada em 1939, na Califórnia, USA (FAWCETT, 1946 e FAWCETT e WALLACE, 1946), e "bud-union decline" verificado em 1941 na Austrälia (McALPIN, et alii, 1948) e "stunt bush" em 1941 em Nova Gales do Sul, na Austrā lia (BUSBY, 1953). De acordo com costa et $\alpha$ lii (1950) o "stem pitting" da Africa do Sul e a tristeza seriam problemas ocasionados por um mesmo virus ou por componentes de um complexo de virus, sendo confirmado por diversos autores tais como, HUGHES e LISTER (1953), Mc CLEAN (1950), MC CLEAN (1956) e WALLACE (1976).

MÜLLER (1968), considera o nome "tristeza" co mo o mais indicado para designar as vārias manifestações induzidas nos citros pélo patógeno. 
2.1.2. Histōrico e distribuição geogrāfica

A Tristeza foi reconhecida no Sul da Africa ao redor do ano 1900 (WEBBER, 1943) e em 1945 tinha sido pro pagada na Colonia Costa de 0uro (DUCHARME, 1951). Em 1926 a doença foi reconhecida em Java (TOXOPEUS, 1937 e VALIELA, 1948), aliảs provavelmente jả existia no ano 1915 (OCHAE, 1949). Existe a possibilidade de que a doenca fosse assinalada, embora não confirmada, em Puga (Índia), com anterioridade a 1920 (Brown, 1920, citado por DUCHARME, 1951). Ex Cei 1ão, em 1945, foram estudadas dificuldades com enxertos de citros (RICHARDS, 1945).

MOREIRA (1967) e ROISTACHER (1976), concluiram que provavelmente a Tristeza foi endémica na Ásia, prime ramente China, India, Indochina e Japão. Sendo que a histöria da movimentação da Tristeza encontra-se diretamente asso ciada ao movimento de borbulhas infectadas. Assim, dizem os autores, durante o período de 1840 a 1940 , pouco conhecia-se sobre as viroses e o movimento de borbulhas foi livre entre os paises. A Tristeza foi trazida da §sia para a Árica do Sul e Austrália, provavelmente com as primeiras importaçós de borbulhas. Existem registros de borbulhas vindas do Sul da Africa e Austrália para a Argentina em 1930 e 1931, que possivelmente introduziram a doença na América do Sul (WALLA CE, 1956). Essa doença foi constatada em São Paulo em 1937 (BITTANCOURT, 1940).

Ê também muito provāvel que o eficiente inse- 
to vetor Toxoptera citridus também tenha sido importado da Årica do Sul para a América do Sul (ROISTACHER, 1976). Em 1939 uma doença similar foi assinada nos pomares de citros da Califórnia ocorrendo um räpido declínio ("quick decline"), das plantas afetadas pela doença (BENNETT e COSTA, 1949).

Atualmente a Tristeza ocorre nas äreas. mais importantes de cultivo de citros da América do Sul, do Norte, Africa, Asia e Austrälia. Na Europa, na bacia do Mediterrâneo, o virus està presente na Espanha. Na maioria das regiões, a Tristeza já se encontra firmemente estabelecida, existindo, no entanto, äreas nas quais o virus é encontrado somente em focos constituidos de plantas isoladas, como no caso de Israel (MÜLLER, 1976).

\subsubsection{Etiologia}

Em 1946 FAWCETT e WALLACE, nos Estados Unidos demonstraram experimentalmente que o "quick décline" era transmissivel por enxertia e portanto uma doença de natureza virótica (FAWCETt e WALLACE, 1946 e WALLACE e FAWCETT, 1947). No Brasil, MENEgHINI. (1946) demonstrou que a mesma podia ser transmitida por um afidio, o Toxoptera citricidus, confirman do a hipótese de BITANCOURT (1944) de que a doença poderia ter caráter virótico. Posteriormente, BENNETT e costa (1948, 1949) demonstraram a transmissão por enxertia e por inseto ve tor ficando estabelecido que a causa da Tristeza era um vi- 
rus. Recentemente, GARNSEY et alii (1977) conseguiram trans mitir mecanicamente o virus e RETUERMA e PRICE (1972), evidenciaram a transmissão do virus no estilete do afidio, sen do retido por um periodo máximo durante o tempo de alimentação de seis horas e sẹr adquirido em só quatro a cinco segun dos .

A primeira electro-fotomicrografia do virus mostra particulas filiformes ao redor de 2000 micras de comprimento e 10-12 micras de diāmetro, sendo realizado por KITAJIMA e colaboradores em 1964 no Brasil (SALIBE, 1973).

os trabalhos pioneiros na purificaça parcial de virus da Tristeza iniciados por SILVA et alii (1965), BAR-JOSEPH et ali $i$ (1970) e BAR-JOSEPH e LOEBENSTEIN (1974), permitiram o desenvolvimento de uma série de trabalhos na àrea, o que associada as técnicas de microscopia eletronica e serologia tinham feito, dos estudos da doença, as mais cientificamente pesquisadas no mundo das ciências fitopatolo gicas; entre eles possuem relevante importanciá OLIVEIRA (1964), SILVA et alii (1965), PRIMO et alii (1971), BAR-JOSEPH et alii (1974), GONÇALVES et ali $i$ (1977), BAR-JOSEPH et alii (1978), GARNSEY, et alii (1979), BAR-JOSEPH (1979), BAR-JOSEPH et alii (1979). 


\subsubsection{Racas ou estirpes do virus da Tristeza}

Desde que ficou comprovado que a Tristeza era provocada por um virus, a existência de mais de uma estirpe ou raça se tornou teoricamente possivel. Assim, em 1951, GRANT e COSTA (1951) e GRANT (1959), demonstraram a existência de diferentes raças ou estirpes do virus e lograraul ie tificar pelo menos duas estirpes, uma severa e outra fraca as vezes em um complexo. A estirpe fraca, encontrada em plantas aparentemente sadias, dava origem a sintomas fracos em plantas testes, ao passo que a outra, existente em plantas com sintomas mais evidentes, sempre ocasionava, nas plan tas inoculadas, fortes sintomas de Tristeza. Na mesma forma KNORR (1956), relatou aparentes similitude e diferenças entre a Tristeza em Amërica do Norte e América do Sul.

Numerosas raças ou melhor ainda, isolados com diferentes caracteristicas são conhecidos (COHEN, 1967 e BOVE, 1967 ). Trabalhos cientificos conduzidos em vārias äreas de pesquisa no mundo demonstraram que o virus da Tristeza deve existir numa multiplicidade de estirpes variando desde extremamente fraca a muito severa, de acordo com o grau de expres são do sintoma na planta teste. Testes de proteção cruzada com fontes de virus selecionado resultou com certo efeito protetor (SALIBE, 1973). Contudo, diz o autor, misturas de estirpes de virus ocorrem dentro de uma dada planta hospede $\underline{i}$ ra 
Estirpes de virus com aumentos na severidade tem sido denominados $\mathrm{T}_{1}, \mathrm{~T}_{2}, \mathrm{~T}_{3}, \ldots \mathrm{T}_{\mathrm{n}}$ e aparentemente as estirpes mais severas estão tambẻm acompanhados por estirpes mais fracas. Por exemplo, uma planta infectada com $T_{3}$ também produz $\mathrm{T}_{2}$ e $\mathrm{T}_{1}$. $\mathrm{E}$ tem sido sugerido que os componentes destas estirpes podem ocorrer nas plantas em diferentes proporções induzindo graus variáveis de expressão de sintomas entre as diferentes plantas infestadas e ramos da planta (SA LIBE, 1973). Fatos estes demonstrados por GRANT e COSTA (1951), costa et alii (1954), costa (1956), OLSON (1956), GRANT e HIGGINS (1957), GIACOMETTI e COSTA (1958), MULLER e COSTA (1967), MÜLLER et alii (1968) e MÜLLER et alii (1969), entre outros.

GRANT e HIGGINS (1957), assinalaram que a pré sença de misturas de estirpes de virus na planta parece estar relacionado com o fato de que qualquer uma estirpe pudes se tornar sistemica, assim deixando äreas suscetiveis para o desenvolvimento de outras estirpes.

Segundo SALIBE (1973), todos os complexos das estirpes de virus da Tristeza, provavelmente foram introduzi dos na maioria das äreas que produzem citros. Contudo, diz o autor, componentes de estirpes e expressão de doenças variam de país para país. Sendo o fato atribuido principalmente às condições climảticas, diferenças nas reações das hospe deiras, e mais extensivamente em diferenças na habilidade de espécies de afídios para extrair e transmitir as estirpes do 
complexo da Tristeza.

\subsubsection{Sintomatologia}

A sintomatologia da Tristeza dos citros tem sido estudada por diversos autores nas äreas nas quais a doença tem sido observada. Baseado nas informações organiza das e resumidas apresentadas por SALIBE (1973), MÜLLER (1976) e MÜLLER (1980), existem 3 sintomas reconhecidos causados pelo virus da Tristeza: (a)"stem pitting"; (b) declínio tipico de Tristeza e (c)"seedling yellows". Embora ARAUJO e VASCONCELLOS (1966), relataram como novo sintoma da doença as rachaduras na casca das plantas de lima mexicana e lima taiti.

(a)"Stem pitting"- Ocorre em pomelos e em mui tas espécies cítticas e é caracterizado pelo desenvolvimento de caneluras ou sulcos longitudinais na superficie do xilema do tronco e ramos.

Saliēncias, correspondentes a e ssas caneluras, podem ser observados na face interior da casca que pene tram nas mencionadas depressões. As caneluras podem ser encontradas nos ramos mais finos, scndo visiveis, em alguns casos, mesmo sem se retirar a casca do lenho. As plantas doentes mostram desenvolvimento lento, decrescimo no vigor e alguns frutos deformados. 0 "stem pitting" $\ddot{e}$ induzido em 
.14 .

hospedeiros intolerantes por muito fraca, média ou forte ra ças de Tristeza.

(b) Declinio tipico de Tristeza - E a sintomato logia da Tristeza na sua concepça clássica, isto é, aquela observada em combinações de citros suscetiveis ao virus,tendo como porta-enxerto a laranja azêda. É caracterizada por folhas ligeiramente bronzeadas, aspecto coriäceo, quebradiças; em alguns casos, amarelecimento da nervura principal ou então amarelecimento total das folhas velhas, declinio rá pido da planta, seca gradativa dos galhos a partir das extre midades "dieback", necrose dos tubos crivados da laranja azé da, podridão das radicelas e, finalmente, morte da planta na maioria dos casos. PRICE (1968), assinalou a condição de restrição do virus da tristeza aos tecidos do floema na plan ta. Afirmação comprovada por CAPOOR (1975) ao estudar o papel do virus da Tristeza no complexo "die-back" dos citros. De acordo com SCHNEIDER (1959) o virus ao causar necrose nos tubos do cavalo de laranja azeda,junto da linha de união do enzerto, impede a passagem dos carbohidratos, as reservas de amido são consumidas debilitando as raizes, seguido por declinio e morte da copa. 0 declinio pode ocorrer em 2 a 4 meses, afetando toda a folhagem e posterior morte da árvore.

$$
\text { (c) "Seedling yellows" - É uma reação de cer- }
$$
tos tipos de citros com tecidos extremamente intolerantes. E, provavelmente, uma reação de hipersensibilidade induzida artí ficialmente quando se inocula com raças ou estirpe severas 
do virus. Não ocorre naturalmente no campo. Mudinhas novas de pé franco de laranjeira Azèda, limão verdadeiro, pomelo e ou mesmo limão Galego, quando inoculados por união de tecido ou grande número de afidios viruliferos coletados da planta afetada por estirpes fortes do virus da Tristeza, manifestam forte amarelecimento das folhas novas e formaça de folhas pequenas, que geralmente ficam retorcidas. Em casos muitos severos, o crescimento quase é paralizado.

Muitos autores consideram a Tristeza como um ünico virus e com numerosas estirpes ou racas. As diferenças na sintomatologia as quais são atribuidas a' diferentes reações do hospedeiro para as diferentes raças foram antes mencionadas. Contudo, alguns autores consideram que existem 2 viroses distintas, associadas no complexo do virus.

MCCLEAN (1960, 1963) e WALLACE e DRAKE (1972) consideram que o "seedling yellow" seria causado por um complexo, de: (a) Tristeza, a qual é facilmente separada, e (b) um virus não identificado, o qual não póde ser isolado do virus da Tristeza. Outros autores consideram, no entanto, que o "seedling yellow" pode ser causado por estirpe do complexo tristeza (COSTA et alii, 1954 e STUBBS, 1964), e atribui as reações da planta à seletividade em adquirir estirpes. Mais recentemente, e constituindo-se uma afirmação com muita validade, CAPOOR (1965) e MÜLLER (1976), consideram esse tipo de sintoma uma manifestaça do virus da Tristeza. 


\subsubsection{Reacão de tipos de citros}

Importantes estudos tem sido desenvolvidos vi sando a agrupar ou diferenciar as reações dos diferentes tipos de citros à infecção pelo virus da Tristeza, sendor os mais indicados os trabalhos realizados por BENNET e costA (1949) e COSTA et alii (1949) enumerados e resumidos por SA LIBE (1973) e MÜLlER (1976). os autores são da opinião que as reações são decorrentes de duas caracteristicas e conclui ram: a) a possibilidade que o virus tem de se multiplicar na planta ou a capacidade da planta a permitir a multiplicação do virus e, b) ao grau de tolerāncia dos tecidos à presença do virus. Assim, dizen os autores, os citros podem pertencer a um dos cinco grupos ou classesínumerados adiante:

GRUPO I - Tipos extremamente intolerantes

Os tipos de citros incluidos neste grupo ou classe são extremamente sensiveis a infecção pelo virus da Tristeza; ou seja,os tecidos do floema são bastante sensiveis. A multiplicaça do virus na planta é nula ou muito pequena por morte das cēlulas no ponto de entrada do virus: Assim, plantas usadas como copas ou pé franco se tornam resistentes por hipersensibilidade de seus tecidos. Embora, estirpes fracas possam ser sistemicas. nas plantas deste grupg e escasso "stem pitting" pode ocorrer. Quando usados como porta-enxertos, tipos deste orupo,podem,parte das partí culas do virus descer da copa ao porta-enxerto, matar cer- 
tas células do floema e abaixo da linha de enxertia mostrar sintomas de Tristeza. "Seedling"destas variedades ou tipos mostram reações de "seedlings yellow", quando inoculados com estirpes severas do virus.

Pertencem a este grupo a laranja azềa, alguns 1 imões verdadeiros, a Severina buxifolia (Poir) Tenore, hibridos de Fortunella sp. e certas variedades de toranjas (C. grandis).

\section{GRUPO II - Tipos intolerantes}

A planta pode permitir a formação de concentrações moderadas de virus e possuir floema moderadamente to lerante a injüria. Estirpes fracas,e muito fracas,do virus podem induzir sintomas de "stem pitting", enquanto as mais severas matam as células e não se tornam sistêmicas. Plantas deste tipo ou pertencentes ao grupo, quando usadas como porta-enxerto e inoculadas com grandes quantidades do virus podem mostrar sintomas tipicos de Tristeza. A éste grupo pare cem pertencer algumas toranjas [C. grandis (Linn.) (Osb.)] e zamboas e algumas limas. Variabilidade na severidade de sin tomas de "stem pitting" seguirão, ém diferenças genéticas, no grau de suscetibilidade ao virus. Alguns podem mostrar sintomas de "seedling yellow". 
A planta pode permitir a produção de concentrações médias ou elevadas de virus e possuir floema bastante tolerante a injüria. Mostra sintomas de "stem pitting" com grau de severidade dependendo da estirpe do virus e o grau de suscetibilidade do tecido da planta, o qual é muito variävel nos tipos deste grupo. Em geral, quando enxertados sobre laranja azêda ou cavalos pertencentes aos grupos I, II e V, mostram sintomas de Tristeza. A este grupo pertencem limas äcidas, gēnero Papeda, certos tangelos, muitos híbridos de limão, limequats e kunquats, calamondin, cidras, 1 imas doces, certos citranges, alguns tangores, e certas varie dades de laranja doce, segundo MüLLER (1976).

\section{GRUPO IV - Tipos tolerantes}

os tipos de plantas de citros que pertencem a esta classe ou grupo, podem permitir muita ou nenhuma multiplicação de raças do virus, mas possuir floema tolerante à concentraçoes elevadas de virus. Exemplos desta classe ou grupo são as tangerinas, a maioria das laranjas doces, a maioria dos tangelos e tangores, limão rugoso, limão cravo e outras limas - tangerinas e Citrus volkameriana. Inclui MÜLler (1976), também o Poncirus trifoliata e alguns de seus hibridos. As tangerinas são as mais tolerantes dentro 
do grupo,e raramente apresentam sintomas de "stem pitting". Os cultivares de laranja doce mostram diferentes graus de tolerância e podem mostrar "stem pitting" na prasença de raças severas do virus.

\section{GRUPO V - Tipos resistentes ou imunes}

Existem critérios opostos entre os autores na definição das bases das reações que ocorrementre a planta ou hospedeiro e o virus. Assim, Müller (1976), diz que a planta pode permitir as produções de concentrações relativamente elevadas de virus e possuir floema sensivel a injüria, afirmando não existir uma diferenciação nitida entre os tipos do grupo II e os tipos deste grupo, e assinala como caracteristica principal das plantas do grupo, mostrar sintomas de pé franco, estando incluidos limas äcidas e alguns po melos. SALIBE (1973), pelo conträrio afirma, como reação dos tipos ao virus, a de não permitir a multiplicação do virus nos tecidos das plantas e não são recuperados dos seedlings, as vezes, apōs a inoculação. Inclui o autor, como representante do grupo o Poncirus trifoliata e seus hibridos.

2.2. Método de indexação da doença

A identificação das viroses dos citros tem sido baseada principalmente no diagnóstico de sintomas em 
plantas no campo ou na inoculação de enxertos de citros em plantas indicadoras, o qual tem sido a maneira mais confiavel na sua identificação, embora possam existir alguns problemas como o período de incubação, relação virus-hospedeiro, condições climáticas favorảveis, facilidade de casa de vegetação e pessoal com experiēncia na leitura dos sintomas (GARNSEY, 1973).

Com relação à indexação de plantas cítricas para constatar se uma planta está ou não infectada com o virus da Tristeza, MOREIRA et ali $i$ (1954), relatam que para mai or rapidez na obtenção dos sintomas da Tristeza, pode-se usar o "teste do limão galego", baseado na grande sensibilida de dos tecidos das plantas desta variedade. Quando infectadas pelo virus elas mostram sintomas (palidez das nervuras e "pitting") mesmo em pés francos ("seedlings")

Também tem sido empregado a enxertia para o "teste da azeda". Assim, diz o autor, as plantas provenientes de sementes de laranja azeda ou de limão galego são conservadas em ambiente livre de infecção natural e, quando seu porte permite realizar enxertia, esta é feita com borbulha ou garfo das plantas doentes.

Empregandorse cavalos de azeda, hà necessidade de se provocar a brotação da borbulha, cujo primeiro cres cimento è geralmente normal. Cerca de très meses mais tar- 
de, diz o autor que vão aparecer sintomas da Tristeza no enxerto.

$$
\text { Quando o cavalo é do grupo do limão galego, }
$$
basta que a borbulha "pegue", com soldadura dos tecidos; os sintomas da Tristeza aparecerão na própria copa do cavalo ao cabo de 30 dias, independentemente da brotação do enxerto.

Na Austrälia, Fraser (1952), citado por GRANT (1959) utiliza limão Eureka [C. limon (L.) Burm], laranja Se vilha (Citrus aurantium) e pomelo (C. paradisi Macf.), para detectar a infestação do vírus da Tristeza dos citros em àrvore do campo. Infectadas com raças fracas reproduzem sinto mas fracos sobre a variedade de lima "key", mostrando a estabilidade das raças. Ao transferir o virus de plantas das di ferentes espécies inoculadas com raças fortes e severas do vírus para a lima "Key", não existia nenhuma alteração' das raças inoculadas ou nas misturas de raças, mostrando graus ou classes de sintomas das diferentes raças testadas, os quais tinham variação para as outras espécies cítricas utili zadas como plantas teste.

GRANT e HIGGINS (1957), descreveram a presença de diferentes sintomas do virus da Tristeza utilizando o limão Galego como planta teste, pelo qual concluiu à possivel existência de raças ou mistura de raças do vírus. As sintomatologias apresentadas eram de atrofiamento, nervuras claras, aclaramento de nervuras, "pitting" no ramo, sen 
do que cada sintoma correspondia a uma raça do virus.

GRANT et alii (1961), ao estudar a reação das variedades de citrus ao virus da Tristeza no Brasil usando värios porta-enxertos e suas combinações, relatam que nas inoculações com raças fracas e severas do virus para comparar os sintomas foram achados diferenças utilizando laranja doce (Citrus sinensis (L.) osbeck), 1aranja azèda (Cithus au rantium L.), suas combinações como cavalos, e limāo Galego.

WALLACE (1968), tambëm recomendou o "1imoeiro -Galego" como a melhor variedade para indexação do virus da Tristeza. Relatou que os sintomas podem ser percebidos três a quatro semanas após a inoculação. Como principais sintomas assinalou: clorose das folhas terminais, nas brotaçós novas após a inoculação; margens das folhas voltam-se para cima; leve amarelecimento das nervuras. Diz o autor que após trēs meses da execução da inoculação e posterior poda, se não aparecer sintomas foliares, as plantas devem ser examinadas para verificar se há "caneluras", pela remoção da casca no tronco e ramos finos. A planta podem ser considera da sadia se após os seis meses da inoculação as plantas tes tes não apresentarem sintomas foliares e "caneluras".

NARIANI e RAYCHAUDHURI (1971), reportam a uti lização da lima Kagsi, Indian West lime, Mexican Lime ou 1imão Galego (Citrus aurantifolia (Christm) swing.) como indica dor para detectar a presenca de vírus da tristeza em várias 
espécies de citros no nordeste e centro da Índia.

SCHWARTZ (1978), descreve um método de transmissão do virus da Tristeza por enxertia de folha com lima West Indian, e assinala que com a formaça do calo a passagem do virus realiza-se transmitindo virus da Tristeza dos citrus. Ele também deu o nome de enxertia-de-folha, ao méto do.

MONTEVERDE et ali $i(1981)$, diz que a planta indicadora mais importante até hoje na seleção de raças atenuadas de Tristeza, e às intensidades nas sintomatologias da doença, è o limoeiro Galego (Citrus aurantifolia (Christm.) Swingle). Assim, GRANT (1959) e McCLEAN (1974), utilizam lí mão e a combinação da laranja azeda sobre laranja doce, para detectar o grau de injürias da raça e determinar o tempo de apariçãö dos sintomas.

MONTEVERDE et ali $i$ (1981), estudando as raças do virus da Tristeza presentes em Venezuela, relatam as sintomatologias apresentadas na planta teste limão criolo ( $C i$ trus aurantifolia Swingle), o que permite a separação de 3 grupos ou raças severas, raças moderadas e raças fracas. Sen do que os mesmos foram descritos em diversas regiões citrico las do mundo. Os mesmos autores assinalam que o tempo minimo para verificação inicial dos sintomas nas plantas de 1 imão galego, foi de 29 dias, e o máximo de 97 dias. 
2.3. 0 uso do porta-enxerto como controle da doenca

Uma planta citrica é composta de duas partes bảsicas, a copa e o porta-enxerto, dois individuos geneticamente diferentes vivendo unidos simbioticamente. Cada uma dessas partes tem influência sobre a outra e a esse conjunto de copa e cavalo se denomina combinação citrica (SALIBE, 1978). Assim, diz o autor, o porta-enxerto induz qualidades a copa; independentes daquelas produzidas pelo clima e solo, assinalando como principais caracteristicas que são modifica das pelo porta-enxerto: vigor da copa; produtividade; pre cocidade de produção; qualidade da fruta; conservação da fru ta pös-colheita; transpiração: fertilidade do pólen; composi ção orgānica e inorgānica das folhas e frutas; capacidade de absorção, sintese e utilização de nutrientes; tolerāncia a salinidade, resistência a seca, resistência a geada e resistência a doenças e pragas. Essas características, relata o autor, resultam de interações especificas entre a copa e o cavalo, que se manifestam por alterações anatómicas, morfoló gicas e metabölicas.

Convëm ressaltar que a interdependēncia entre a copa e o porta-enxerto é afetada em graus variāveis por ou tros fatores tais como: as doenças viróticas, condições de solo, niveis de nutrientes, chuvas, temperatura, luminosidade, präticas culturais, pragas e outras influéncias. Viroses para as quais os tecidos do enxerto são tolerantes, descendo com a seiva ou pela invasão das células de uma das par 
tes do enxerto por proteinas tóxicas da outra, afetam profun damente o porta-enxerto, desvitalizando ou acarretando a mor te da ärvore toda (SALIBE, 1974).

Entre as enfermidades que afetam os citros causando maiores prejuizos a Tristeza e a gomose de $P$. para sitica estão diretamente relacionadas a resistēncia ou tolerância de porta-enxerto, aliàs um porta-enxerto demonstra sua real capacidade de imprimir vigor e produtividade na ausēncia de enfermidade, em especial aquelas de natureza virótica (SALIBE, 1978). Assim, ao ser a Tristeza considera da uma doença endēmica no Brasil, a utilização de porta-enxerto resistentes ou tolerantes ao virus deverá ser o meio mais prático e eficiente no controle da doença.

A Tristeza tem sido um dos principais fatores responsável pelas mudanças de porta-enxerto para citros nos principais países produtores, onde a doença foi detectada (MOREIRA e SALIBE, 1969).

Centenas de variedades e espècies de Citrus e generos afins foram testados por sua tolerância ao vírus da Tristeza. Trabalhos pioneiros, após a introdução no País, fo ram iniciados com a utilização de porta-enxertos, denominados tolerantes ao virus da Tristeza, entre eles VASCONCELlos (1939), MOREIRA (1941), BRIEGER e MOREIRA (1945), MOREIRA (1946), COSTA et alii (1954), MOREIRA (1954), MOREIRA (1956), MONTENEGRO (1960), MOREIRA et alii (1960), MOREIRA et alii 
(1962), MOREIRA e ROESSING (1965) entre outros, e que no caso da América Latina, para o ano de 1969 , poderiam ter tido um nú mero, segundo MOREIRA e SALIBE (1969), calculado em mais ou menos cem trabalhos.

Contudo, convém lembrar, que observações posteriores mostraram, entretanto, que nem todos os tipos de co pas comerciais desenvolveram-se satisfatoriamente em cavalos tolerantes na presença do virus da Tristeza (CostA, 1956; MO REIRA, 1959 ; GIACOMETTI, 1961 ). 


\section{MATERIAL E METODOS}

\subsection{Pomar experimental}

As plantas estudadas fazem parte de um experi mento de competição de cinco variedades de laranja doce e cinco porta-enxertos. Tem 19 anos de idade, e são provenien tes de gemas e sementes selecionadas de matrizes, individuais para cada caso, pertencentes ao Banco de Germoplasma Sadio da Estação Experimental de Limeira, dependente do Instituto Agronómico de Campinas. Eram, no inicio, comprovadamente isentas do virus da Sorose, viröide da Exocorte e Xiloporose, e portadoras de uma estirpe de virulència mèdia de Tristeza.

\subsubsection{Variedade enxerto}

A variedade enxerto de laranja doce, Citrus sinensis (L.) osbeck, utilizada foi a laranja 'Westin'.

a laranja Westin, provavelmente proveniente 
do Rio Grande do Sul (Porto dos Clementes), foi considerada como uma variedade nova na citricultura paulista. Era chamada inicialmente de Clementina e depois mudado o nome para Westin em homenagem ao Prof. Phylippe Westin Cabral de Vasconcellos, professor emërito da Universidade de São Paulo (MOREIRA, 1961 ).

A descrição da variedade e de suas principais caracteristicas foi realizada por SALIBE (1972), SALIBE e MO REIRA (1972), FOGUET (1978) e ANDRADE et alii (1981), como segue:

São ärvores grandes, copa arredondada ou ovalada, vigorosas, folhagem abundante e ramos espalhados.0 seu florescimento tem maior intensidade no més de agosto e maturação meia estação. Folhas oblongas largas, com apice agudo e base obtusa sendo a margem levemente serreada. Apresenta pecíolo alado. Folhas alternas, com àngulo de divergéncia igual a 2/5. Flores completas com cälice persistente, pentạ meras e 21 estames. Frutos, quando maduros são de casca ama relo-alaranjada a laranja forte, superficie levemente rugosa

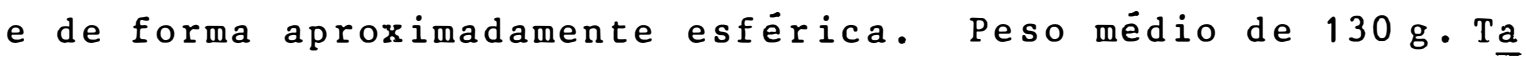
manho: $6,1 \pm 0,6 \mathrm{~cm}$ de comprimento e $6,4 \pm 0,6 \mathrm{~cm}$ de 1 argura; nümero de sementes: 3 a 6 ; nümero de gomos: 10 a 12 ; espess ra da casca: $0,4 \pm 0,1 \mathrm{~cm}$. Anälises do suco: porcentagem de suco $45 \%$ - 50\%, porcentagem de acidez $1,30 \%$; sólidos solúveis: 9,12 a $11,7(\%)$; àcido ascórbido $78 \mathrm{mg} / 100 \mathrm{~m} 1 \mathrm{de}$ suco; sabor äcido doce, com relação acidez/sólidos solúveis $1: 11,2$ e suco de coloração laranja-pálido. Plantas com alguns sintomas de "stem pitting" em ramos jovens e muito suscetivel a 
um fungo, possivelmente Phomopsis sp. que causa um secamento dos ramos terminais.

\subsubsection{Variedades porta-enxertos}

os cinco porta-enxertos utilizados foram:

a. Limoeiro Cravo, (LC), (Citrus limonia osbeck), também conhecido pelos nomes de Rosa, Vermelho, Bravo, Francès, Vinagre e Rangpur; é uma planta de porte médio, bastante produtiva. Sistema radicular, conforme MONTENEGRO (1960), com $70 \%$ de suas radicelas situadas nos $30 \cdot \mathrm{cm}$ superio res do solo. Sementes pequenas, dez a quinze por fruto e do ze a quinze mil por quilo. E intolerante a viroide da Exocor te e Xiloporose e muito suscetivel ao fungo da verrugose, El sinoe fawcetti Jenk. Tem suscetibilidade média ao ataque de Gomose de Phytopthora spp. (ROSSETTI, 1947). Tolerante a Tristeza.

b. Limoeiro rugoso da Flörida (RF), (Citrus jambhiri Lush). Planta de porte grande, bastante produtiva. Aproximadamente $81 \%$ das radicelas do sistema radicular desse limoeiro se encontra até a profundidade de $30 \mathrm{~cm}$ da superficie do solo (MONTENETRO, 1960). Sementes pequenas, vinte a trinta por fruto e dez a doze mil por quilo, poliembriónicas. Suscetivel aos fungos da Gomose e Verrugose, e toleran te a viroide daExocorte e Xiloporose. Tolerante a Tristeza. 
c. Tangerineira-Sunki, (SU) (Citrus sunki Hort ex Tanaka). Arvore de porte médio, bastante produtiva, sementes pequenas, dez a quinze por fruto,e doze a quatorze mil por quilo, poliembrionicas. Tolerante a Xiloporose e Tristeza.

d. Trifoliata, (TR), (Poncinus trifoliata Raf). Única espécie do gênero, planta de porte médio a pequeno, bastante produtiva. Sistema radicular localizado, segundo MONTENEGRO (1960), na sua maior totalidade até a profundidade de $30 \mathrm{~cm}$ a partir da superficie do solo. Sementes são grandes, trinta e cinco a quarenta por fruto e quatro a seis mil por quilo; poliembriônicas. Ê intolerante a viroide da Exocorte; tolerante a Xiloporose e Tristeza e resistente a Gomo se, de Phytopthora sp.

e. Laranjeira Caipira, (CA), [Citrus sinensis (L.) Osbeck]. Planta de porte grande, produtiva. Sistema ra dicular estä na sua maior parte localizado nos'primeiros 30 cm do solo, conforme MONTENEGRO (1960); sementes grandes, quinze a vinte por fruto, e cinco a seis mil por quilo; poliembriônicas. Suscetível a Gomose, intolerante ao virus da Sorose e boa resistência ao fungo causador da verrugose. To lerante a Xiloporose, Tristeza e viroide da Exocorte. 


\subsubsection{Localização do pomar experimental}

0 pomar experimental cujas plantas foram utili zadas para realizaça do experimento aqui relatado, está localizado na Estação Experimental "Presidente Médici"(Fazenda Lajeado), da Universidade Estadual Paulista "Julio de Mesqui ta Filho", município de Botucatu-SP, nas coordenadas geográficas $22^{\circ} 52^{\prime} 55^{\prime \prime}$ de latitude sul e $48^{\circ} 26^{\prime} 22^{\prime \prime}$ de longitude oci dental. A altitude é de $830 \mathrm{~m}$.

\subsubsection{Solo e clima}

0 terreno ocupado pelo experimento apresenta topografia levemente inclinada. Segundo COMISSAO DE SOLOS (1960), o solo da ärea Lajeado é classificado como LATOSSOLO ROXO, e caracteriza-se como unidade Lageado-TerraRoxa - Estruturada älica textura argilosa, latossōlica (CARVA LHO et $a$ Zii, 1983).

Os solos são de fertilidade natural média, se gundo a interpretação das anālises químicas de amostras compostas de solo, constante da Tabela 13 do Apēndice citados por SALIBE (1974).

o clima do município de Botucatu conforme o Sistema Internacional de Köeppen, é do tipo Cfb, segundo TUBELIS et alii (1971, 1972) e CURI (1972). É um clima temperado sem inverno seco, temperatura média dos meses mais 
frios inferiores a $18^{\circ} \mathrm{C}$ e as dos meses mais quentes inferiores a $22^{\circ} \mathrm{C}$. Precipitações minimas mensais superiores a $30 \mathrm{~mm}$. Na classificação de Thornthrwaite, a região apresenta clima $B_{1} r^{\prime} z a^{\prime \prime}$, ou seja, clima úmido com pequena deficiência de ågua, mesotērmico, com estações climäticas mal definidas (CU RI, 1972). Os dados dos principais parâmetros climáticos ocorridos durante o desenvolvimento do experimento, encontram -se na Tabela 14 do Apēndice.

3.1.5. Plantio do pomar e instalacão do experimento

0 plantio do pomar foi realizado a 26 de novembro de 1965, sendo que para a data de instalação do experimento (coleta das borbulhas), 15 de setembro de 1983, as plantas tinham uma idade de, aproximadamente, 18 anos.

\subsubsection{Delineamento experimental}

Foi mantido o mesmo delineamento experimental do pomar para realizaça do presente experimento, isto é, o de blocos ao acaso, com seis repetições. Cadabloco do pomar era de cinco parcelas de duas plantas, em um espaçamento de $7,00 \times 7,00$ metros. 0 experimento compreendeu as combinações de uma variedade copa enxertada sobre os cinco porta-enxertos, num total de 60 plantas úteis. 0 delineamento ex 
perimental estabelecido è mostrado na Tabela 15, do Apêndice:

\subsubsection{Tratos culturais}

Os tratos culturais foram sempre uniformemente dedicados a todas as plantas do experimento. A utilização de insumos obedeceu as recomendações gerais que normalmente são utilizados no Departamento de Horticultura do Campus da UNESP, em Botucatu. O combate de ervas daninhas, com preendeu normalmente quatro gradeações, seguidas de controle mecānico-manual de acordo com as necessidades surgidas.

As ärvores não receberam nenhum tratamento fí tossanitārio, e foram conduzidas sem irrigação.

\section{3,1.8. Mensurações}

Para o estudo comparativo do desenvolvimento vegetativo ou vigor das laranjeiras 'Westin' sobre os diferentes porta-enxertos, decidiu-se adaptar o critério da mensuração da circunferência do tronco, conforme indicado por PEYNADO (1958). Os perimetros foram tomados com o emprego de uma fita métrica, no tronco de cada planta, a dez centimetros acima do ponto de união copa-cavalo, em fevereiro de 1984. Com o mesmo objetivo e na mesma data, foram medidas; a altura das plantas, utilizando uma rëgua de madeira 
com seis metros de comprimento, com divisões de 5 em centime tros; e o diâmetro da copa de cada planta em suas orientaçóes Norte-Sul e Leste-0este. Com as medições da altura da planta (A) e diâmetro da copa (D) foi feito o cảlculo do Indice de Conformação da planta (A/D), segundo CEREDA (1981), o que permite obter uma avaliação quantificável da forma ou assime tria da planta.

A área da planta disponivel para produção de frutos e portanto, a máxima ärea atual de produção da planta, foi avaliada pelo uso da "ärea produtiva". Este tipo de avaliação foi desenvolvido por KOO e KREZDORN em 1,967, para avaliar a ärea da copa da laranjeira. É baseado, segundo os autores, na forma paraboloide da copa da planta, e portanto, a förmula é a derivação da àrea da superficie da paräbola. MENECHINO (1983), a utiliza com o nome de "área produtiva", nome mantido no presente trabalho. O cálculo baseia-se na förmu 1a:

$$
- \text { Area }=\frac{2 D}{3 A^{2}}\left[\left(\frac{D^{2}}{16}+A^{2}\right)^{3 / 2}-\left(\frac{D}{4}\right)^{3}\right]
$$

onde $\mathrm{D}$ é o diāmetro da copa da planta e A é a altura da:plan ta. 
A obtenção dos dados de produção de laranjas foi realizado com o controle da mesma, em peso de frutas por planta, em cada safra. As colheitas foram feitas na ëpoca de abril-maio, nos anos de 1968 a 1974 , sendo determinado o peso das laranjas por planta em quilogramas. Embora tenham sido considerados, para os efeitos de anälises estatisticas,

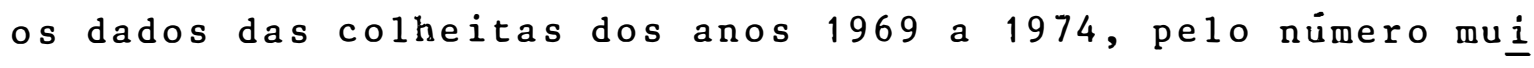
to pequeno de frutos obtidos na safra do ano 1968. Os dados dos parâmetros: no de frutos e no de caixas por parcela foram obtidos a partir dos dados disponiveis das safras do periodo de 1980 a 1982. Esses dados constam do controle do pomar experimental, feito anualmente pela UNESP-Botucatu (SP) e nos foram gentilmente cedidos pelo Prof. Ary A. SAlibe. 
3.1.9. Avaliação do "stem pitting" ou caneluras em ramos das laranjeiras 'Westin'

Para o estudo da incidência e quantificaça de "stem pitting" ou caneluras de Tristeza, retiraram-se 10 ramos novos devidamente identificados, das duas plantas de cada parcela. Foram coletados a altura de $1,50 \mathrm{~m}$ e nas seis repetições, para um total de 600 ramos. 0 s ramos, cada um com cerca de $20 \mathrm{~cm}$ de comprimento e de 5 a $6 \mathrm{~mm}$ de diāmetro, foram descascados após prëvio tratamento com ägua fervente durante 3 horas. Foram avaliados quanto a presenca de "stem pitting" ou caneluras, segundo uma escala de notas de 0 a 5 , por dois avaliadores. Os critérios foram:

Notas

Sintomas

0

Ausência de sintomas de

"stem pitting" ou caneluras no lenho do ra mo. Ramosnão afetados.

1 Presença de "stem pittíng" ou canelu ra em pequenas quantidades, em nümero menor de 4, no lenho do ramo. Ra mos 1 igeiramente, afetados.

Presença de sintomas de "stem pitting" ou aaneluras em número de aproximadamente 6 a 12 "stem-pitting" por ramo, na superficie do mesmo. Ra mos moderadamente afetados. 
Notas

3

Presença de muitos "stem pitting" ou caneluras em nümero maior de 20 , sem deformação no lenho do ramo. Ramos mui to afetados.

4

5

3.2. Kiveiro experimental para indexacão do virus

\subsubsection{Localização}

Para a condução do experimento foi instalado um viveiro experimental, localizado em uma casa de vegetação, com paredes com teto de tela de plästico branco, a prova de afidios, tendo ärea de aproximadamente $36 \mathrm{~m}^{2}$. 
A casa de vegetação estava situada em terrenos da ärea de plantas horticolas, do Departamento de Agri cultura e Horticultura da Escola Superior de Agricultura "Luiz de Queiroz", da Universidade de São Paulo, no município de Piracicaba, Estado de São Paulo, a uma latitude de $22^{\circ} 42^{\prime} 30^{\prime \prime}$.sul, longitude de $47^{\circ} 38^{\prime} 00^{\prime \prime}$ e altitude de $586 \mathrm{~m}$.

\subsubsection{Clima da região}

o clima da região é Cwa, pela classificação climätica de Köppen, ou seja, sub-tropical úmido com estiagem no inverno, com a temperatura média do mês maìs frio inferior a $18^{\circ} \mathrm{C}$ e do mês mais quente superior a $22^{\circ} \mathrm{C}$, também denominado de tropical de altitude por CAMARGo et alii (1974). Os principais parametros climäticos ocorridos durante o desenvolvimento do experimento encontram-se na Tabela 16 do Apêndice.

3,2.3. Obtenção de plantas testes de limão Galego, citrus aurantifolia swingle

As sementes de 1 imão Galego para a formação de plantas, "seedlings", utilizados no experimento foram obti dos na Estação Experimental de Limeira, do Instituto Agronômico de Campinas. As mesmas foram extraidas de frutos maduros colhidos para finalidade do experimento. As sementeiras fo- 
ram feitas em caixas de madeiras nas dimensões de $45 \times 30 \quad x$ $13 \mathrm{~cm}$, num meio formado por terra e areia na proporção $1 \times 1$, coberto com uma camada fina de areia. As caixas foram manti das em casa de vegetação. A semeadura foi realizada em agos to de 1982. Posteriormente, foram transplantadas apös prëvia seleção dos "seedlings" nucelares, para saquinhos plästi cos nas dimensões de $25 \times 30 \mathrm{~cm}$, em novembro de 1982, num mein formado de solo orgānico e areia na proporção 2 : 1 . Nes se local, pulverizações semanais com inseticidas eram efetua das, visando impedir a colonização das plantas pelo pulgão preto dos citros (Toxoptera citricidus Kirk), o vetor da tristeza. Foram feitas adubações mensais, aplicados ao solo e folha.

\subsubsection{Mētodo de indexação do virus}

Foi empregado o teste de limão Galego para a deteção do virus da Tristeza e suas raças, descrito por WAL LACE (1968).

As plantas indicadoras, provenientes de "seedling" nucelares. de limão Galego, foram submetidas a inoculações por enxertia (setembro de 1983), com gemas provenientes de estacas, das plantas das diferentes combinaçóes da. laranjeira 'Westin' e os cinco porta-enxertos utilizados. 
ras de borbulhas, conforme o descrito anteriormente, fazem parte do pomar experimental localizado na Estação Experimental "Presidente Médici", UNESP, Botucatu.

0 método de inoculação empregado foi o de enxertia em "T" invertido, realizando-se 2 enxertias por planta teste para garantir a inoculaça do virus. Apōs vinte dias de realizada a inoculação procedeu-se a verificação da porcentagem de enxertos positivos e realizou-se: uma nova enxertia a fim de manter o número de plantas desejadas. As plantas testes foram mantidas na casa de vegetação e realiza das pulverizações e inspeções continuas para manter as plantas isoladas de afidios.

Três meses apōs a realização das inoculações, os "seedlings" de limoeiro-galego começaram a evidenciar os sintomas caracteristicos da "Tristeza", descrito por WALLACE (196.8), demonstrando que as plantas em teste estavam inocula das com o virus, da "Tristeza".

3.2.5. Avaliação dos sintomas foliares e "stem pitting" ou caneluras nas plantas teste:de li mão Galego

A reação à Tristeza observada nas plantas de limão Galego dos diversos experimentos foi julgada:

(I) pela manifestação de sintomas foliares a presentados (Figura 1): 
Notas

1

2

4

5

A escala arbitraria com notas de 1 a 5 , varia ram, subjetivamente, de acordo com a severidade, segundo metodologia utilizada por MÜLlER (1972) e MONTEVERDE et ali $(1981)$

(II) pela presença de "stem pitting" ou canelu ras, seguindo-se nesse casn o mesmo critërio para avaliar a intensidade de sintomas de "stem pitting" em ramos da laranja 'Westin', descrito em item 3.1.9. 
As avaliações dos sintomas foram realizadas por três avaliadores, sem ordem preestabelecida de inicio da mesma, com idêntica escala e com plantas testemunhas nega tivas ( 1 ivres de Tristeza) e plantas testemunhas positivas $\underline{i}$ noculadas previamente em plantas teste de limão Galego com borbulhas provenientes da mesma região.

\subsubsection{Delineamento estatístico}

o delineamento experimental utilizado foi o mesmo descrito para o pomar experimental, isto é blocos ao acaso, com seis repetições, cada bloco constituiu-se de cin-co parcelas. E cada parcela constituida de oito plantas e sendo que quatro delas correspondiam-se a uma planta da parcela do pomar. Assim, foram usadas quatro plantas teste por planta do pomar no total de 240 plantas testes efetivas, de limão galego. 0 delineamento experimental estabelecido é mostrado na Tabela 17 do Apēndice.

\subsection{Anālise estatîstica}

Foi feita a anälise da variância para os dife rentes parāmetros estudados. As diferenças entre média de porta-enxertos foram testadas através do teste de Tuckey ao nivel de 5\% de probabilidade, conforme PIMENTEL GOMES (1981). As médias calculadas também se apresentam graficamente. 
Com o objetivo de se determinar correlação en tre os parametros estudados foi determinada matriz de corre1ação. Onde houve correlação significativa foi determinado o melhor modelo de regressão simples e sua representação grä fica. Foi usado para esse fim um programa denominado CURVAS, o qual testa 25 diferentes modelos de regressão simples, resultantes das combinações de 5 transformações das variāveis x e y, ou seja:
(1) $x^{\prime}=x$
$y^{\prime}=y$
(2) $x^{\prime}=1 / x$
$y^{\prime}=1 / y$
(3) $x^{1}=x^{2}$
$y^{\prime}=y^{2}$
(4) $x^{\prime}=\sqrt{x}$
$y^{\prime}=\sqrt{y}$
(5) $x^{\prime}=\operatorname{LN} X$
$y^{\prime}=L N \quad Y$

A equação final escolhida foi aquela que apre sentou maior coeficiente de determinaço $\left(R^{2}\right)$.

Ba mesma forma, foram feitos estudos individuais de correlação para cada porta-enxerto, previa seleção das correlações significativas do estudo da matriz de correlação; relacionados com sintomas de Tristeza, segundo o programa CURVAS assinalado anteriormente.

Com o objetivo de separar grupos de porta-enxertos levando-se em consideração todos os parämetros estuda dos foram feitas Anälises dos Componentes Principais e de 
.44. Agrupamento, onde foram considerados os cinco porta-enxertos e as onze caracteristicas: "stem pitting" em ramos da copa da laranja 'Westin', "stem pitting" e sintomas em folhas de 1 imão Galego; altura da planta, diāmetro da copa, circunfe rência do tronco, ärea produtiva, indice de conformação, pro dução em kg/parcela $(1969-74)$, e o nümero de caixas e número de frutos por parcela $(1980-82)$. Através do resultado da Chister Analysis foi elaborado um fenograma, segundo metodologia desenvolvida por Sokal e Michener (1.958) citados por SNEATH e SOKAL (1973). 


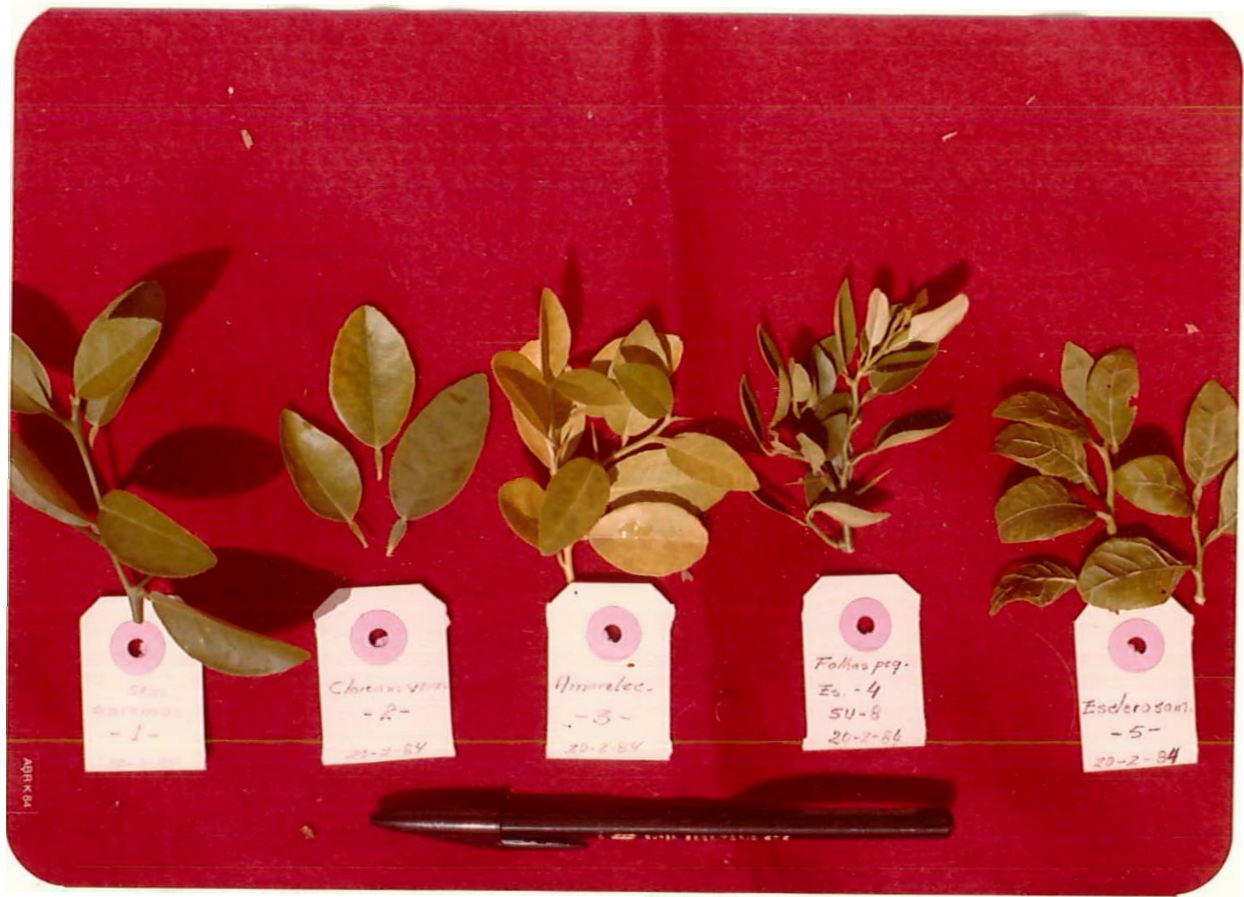

FIGURA 1. Folhas de limoeiro Galego mostrando escala de notas de sintomas do virus da Tristeza, desde sem sintomas até muito severo. 


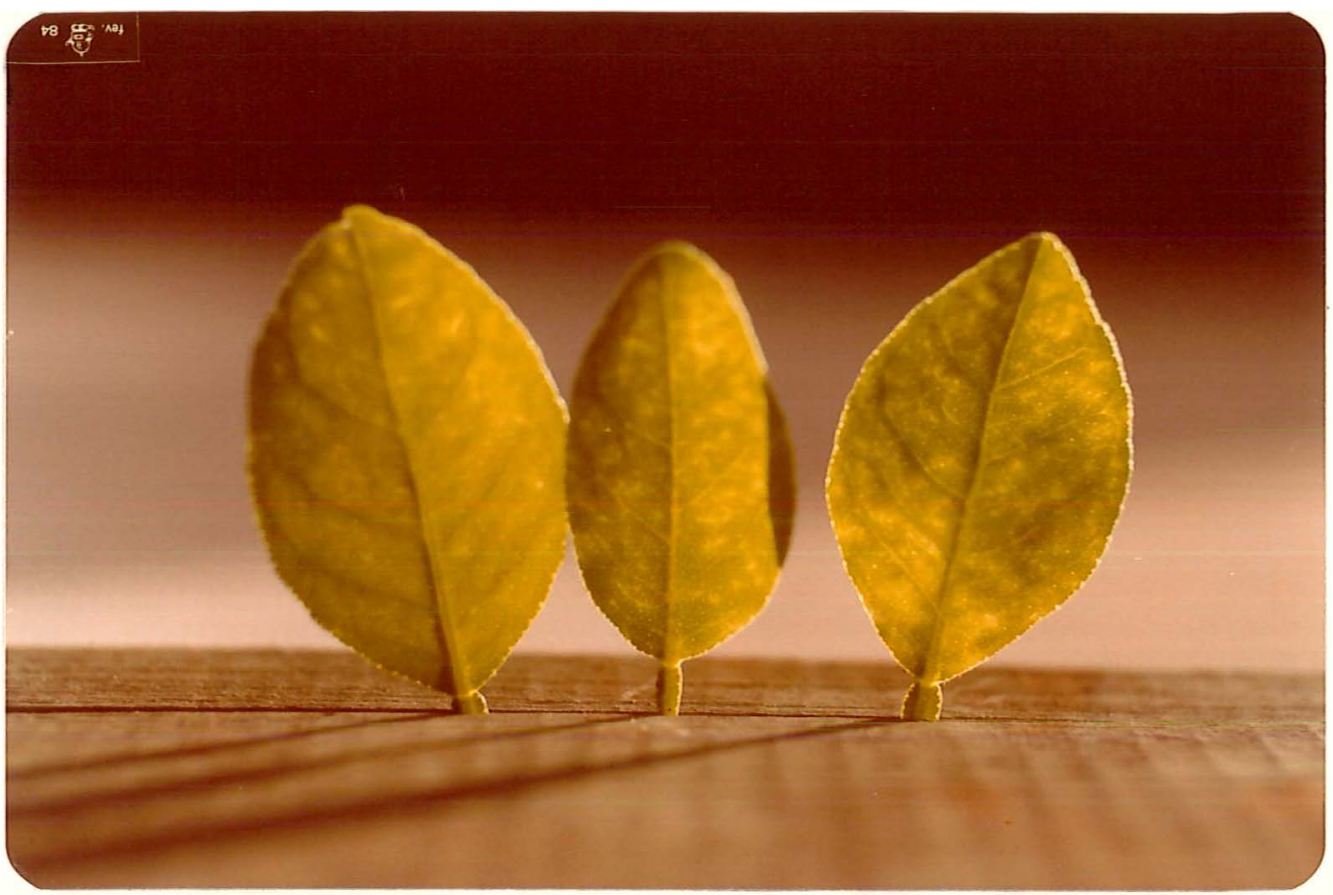

FIgURA 2. Folha de limoeiro Galego mostrando sintomas de pa lidez das nervuras ('Tristeza), destacadas de plan tas inoculadas com borbulhas de laranjeira 'Wes-$\operatorname{tin}^{\prime}$ (Nota 2).

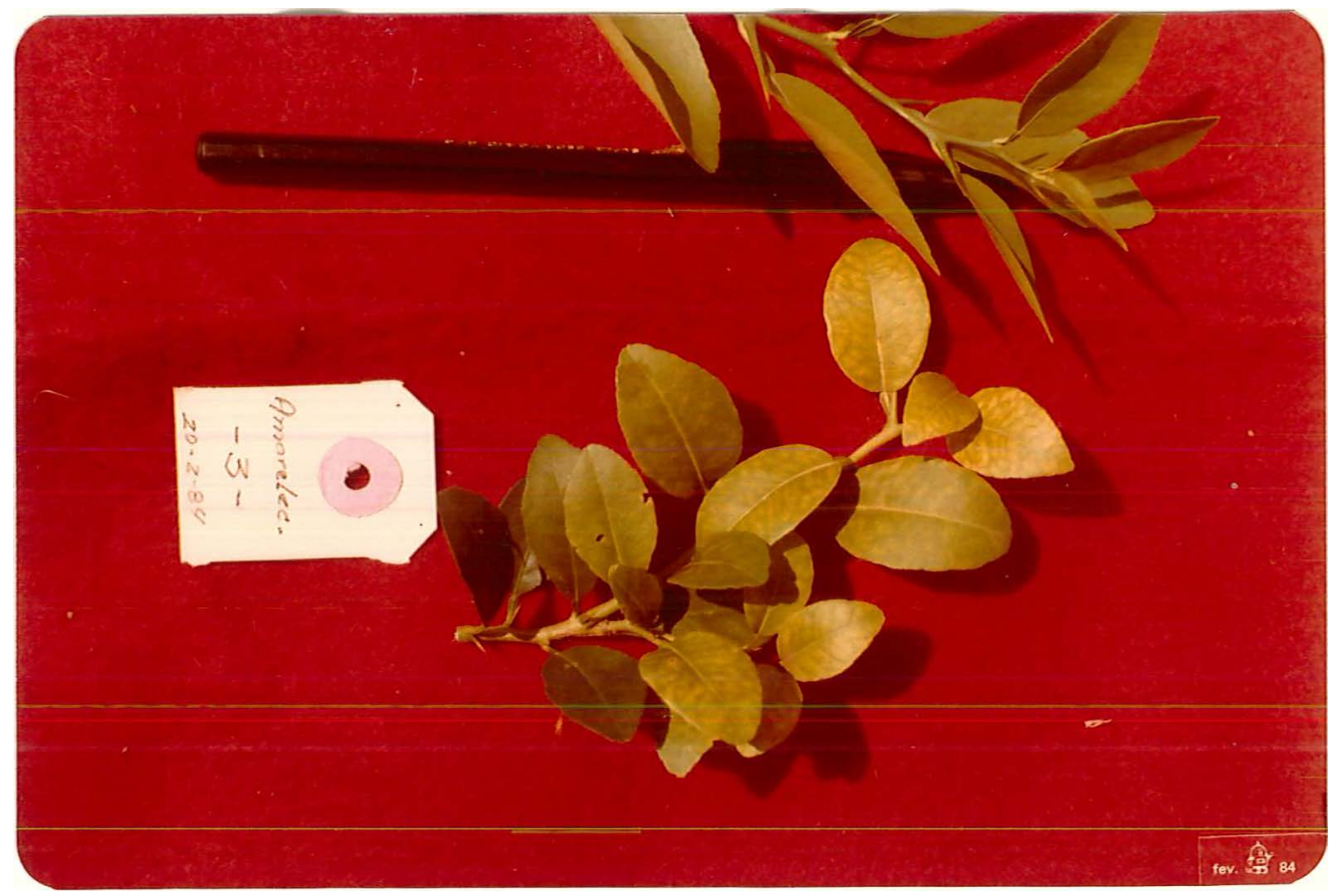

FIGURA 3. Ramos de 1 imoeiro Galego mostrando sintomas do vi rus da Fristeza de amarelecimento (Nota 3 ), desta cado da planta teste inoculada com gemas da copa da laranjeira 'Westin'; lado esquerdo planta sadia. 


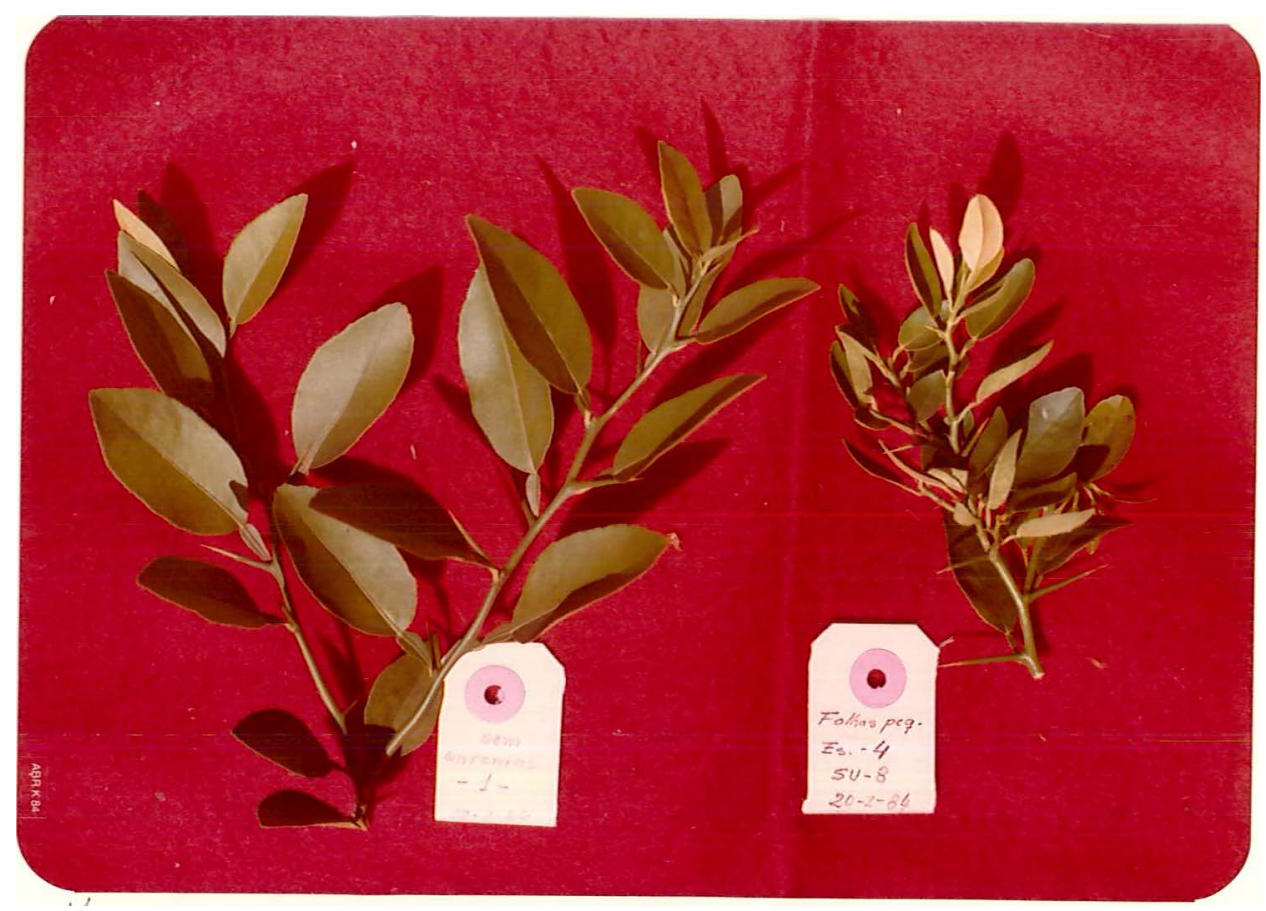

FIGURA 4. A direitaa ramo de 1 imoeiro Galego mostrando sinto mas do virus da Tristeza de "folhas pequenas e cur vas para a face superior" (Nota 4), destacado de planta teste inoculada com gemas da copa da laranjeira 'Westin'; a direita ramos da planta sadia.

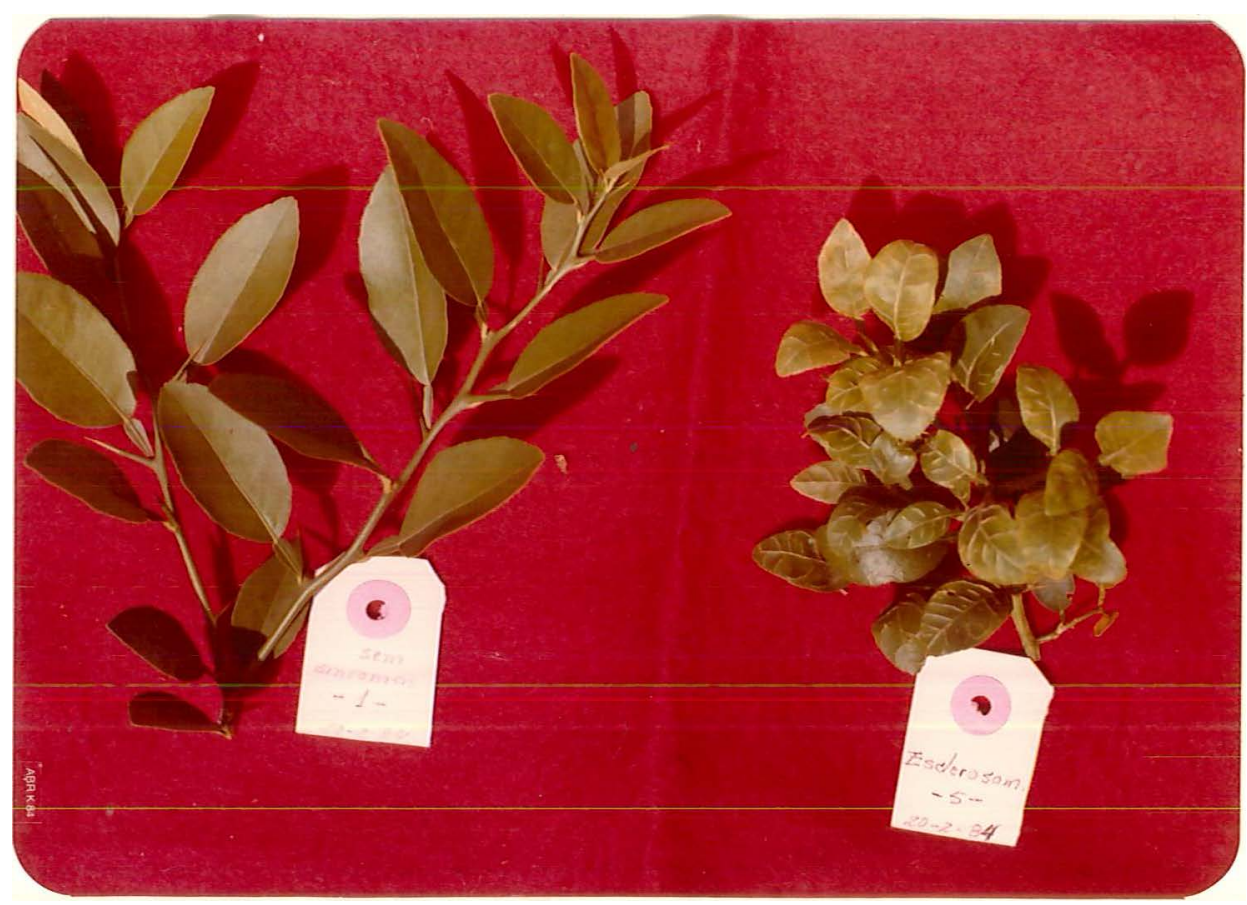

FIGURA 5. A direita, ramo de limoeiro Galego mostrando sintomas de suberificação das nervuras (Tristeza), a di reita ramos de plantas sadias. 
.48.

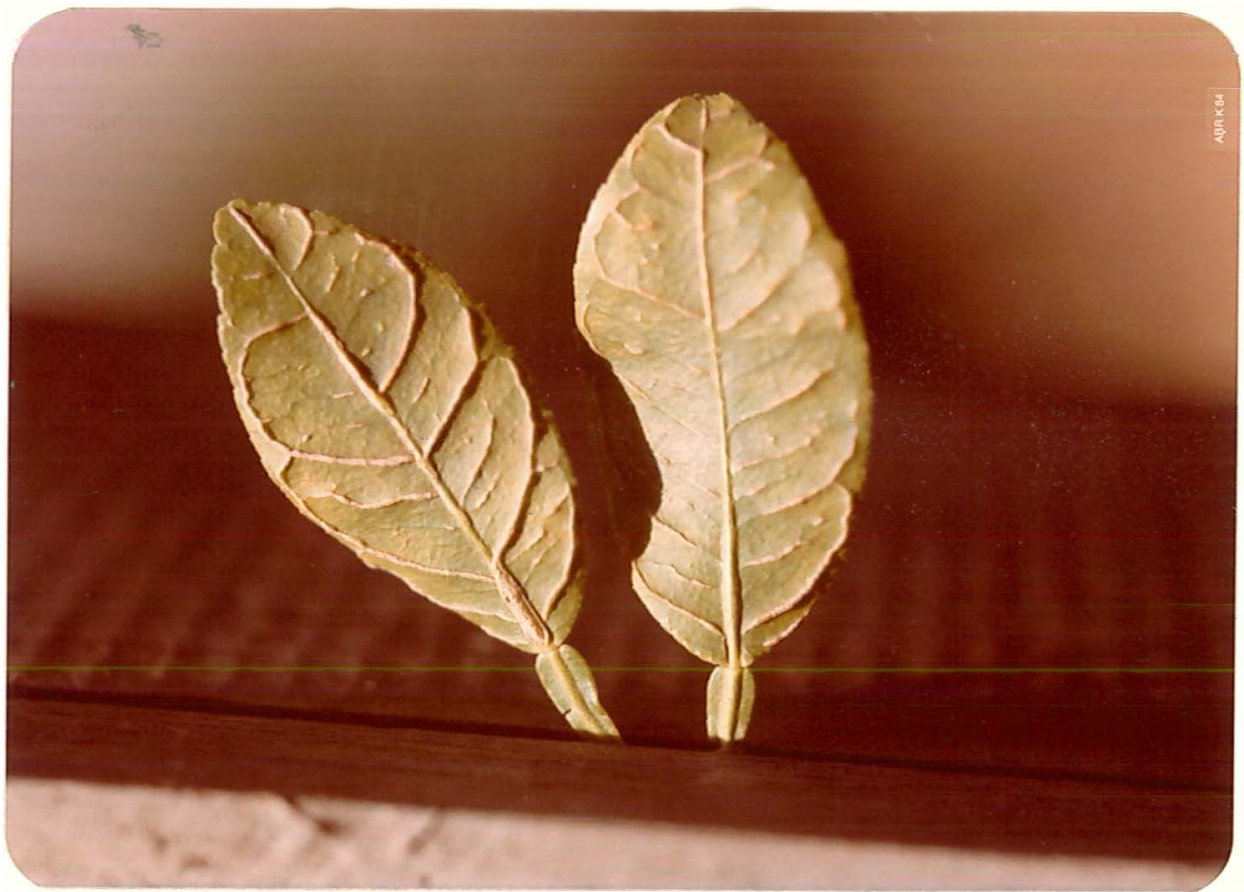

FIGURA 6. Folha de 1 imoeiro Galego mostrando sintomas de suberificação das nervuras (Tristeza dos citros), des tacadas de plantas inoculadas com borbulhas de laranjeira 'Westin' (Nota 5). 
4. RESULTADOS

4.1. Avaliação de sintomas de Tristeza em plantas indicadoras

4.1.1. Avaliacão de sintomas em plantas indicadoras

os resultados das notas referentes as avaliações do teste de Tristeza em plantulas de limão Galego, acham-se nas tabelas de nümeros 18 e 19, no Apêndice.

4.1.2. Anālise estatistica dos resultados

A anấise de variância dos dados do teste de Tristeza, são apresentados na Tabela 1. Não houve diferencas significativas aos niveis de $1 \%$ e $5 \%$ de probabilidade,pe 1o teste F, respectivamente para "stem pitting" ou caneluras e sintomas nas folhas das plantas teste de limão Galego. As 
TABELA 1. Anālise da variāncia das notas médias dos testes de Tristeza em plantas de limão Galego utilizando dife rentes inóculos, provenientes de plantas da laranjeira 'Westin' sobre cinco porta-enxertos. ESALQ-USP, Piracicaba, SP. Fevereiro de 1984.

\begin{tabular}{|c|c|c|c|}
\hline \multirow{2}{*}{ Causa da variação } & \multirow{2}{*}{ G.I. } & \multicolumn{2}{|l|}{$F$} \\
\hline & & $\begin{array}{l}\text { "stem pitting" ou } \\
\text { caneluras }\end{array}$ & $\begin{array}{c}\text { sintomas nas } \\
\text { folhas }\end{array}$ \\
\hline
\end{tabular}
Blocos
5
0,29 ns
1,86 ns

Tratamentos

4.

1,55 ns

2,06 ns

Residuos

20

Tot a 1

29

$\mathrm{CV}(\%)$
n.s. não significativo
$\mathrm{CV}=$ não significativo


comparapcões entre as médias pelo teste de Tuckey a $5 \%$ de probabilidade, encontram-se na Tabela 2. As representações gräficas da comparação entre médias, são apresentadas na Figura 19 do Apēndice.

Na Tabela 3 são apresentados os resultados da seleção dos modelos de regressão simples entre os parâmetros avaliados na sintomatologia do virus da Tristeza, nas plantas teste e ramos da copa, e, parâmetros físicos do desenvol vimento das laranjeiras 'Westin' sobre os cinco porta-enxertos. A análise de regressão simples, mostra que as correlações entre "stem pitting" em ramos e altura de plantae "stem pitting" em ramos e produção (kg/parcela) foram estatisticamente significativas ao nivel de $5 \%$ de probabilidade. Os demais coeficientes de correlação não foram significativos, os pontos observados e estimados pela equação de regressão se encontram plotados nas figuras 7 e 8 , as quais representam as equações de regressão dos sintomas em ramos com os pa metros altura e produção.

As anälises de regressão simples entre a avaliação de sintomas e paràmetros de desenvolvimento em relação aos porta-enxertós são apresentados na Tabela 4. Não hou ve, estatisticamente, correlação significativa. 


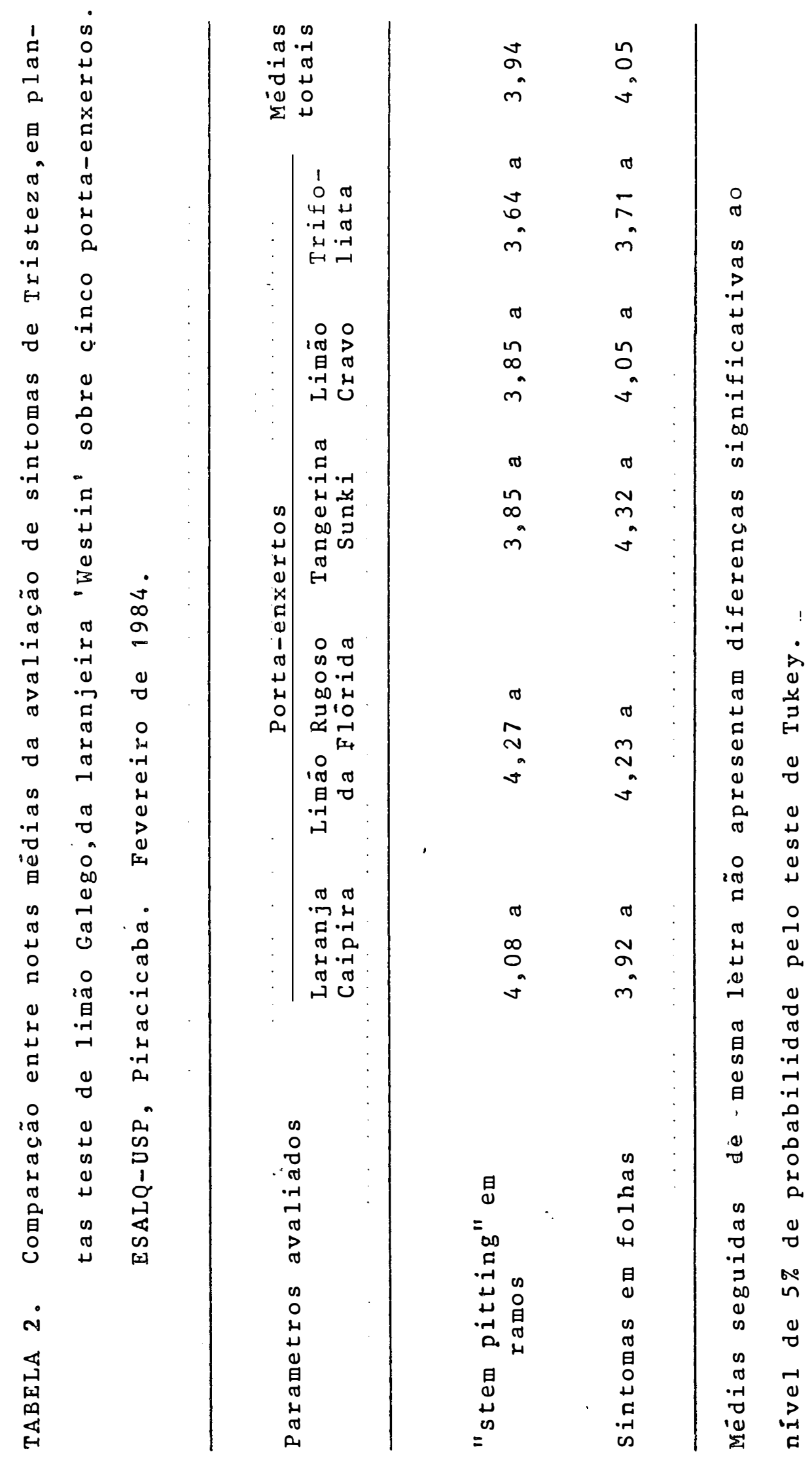




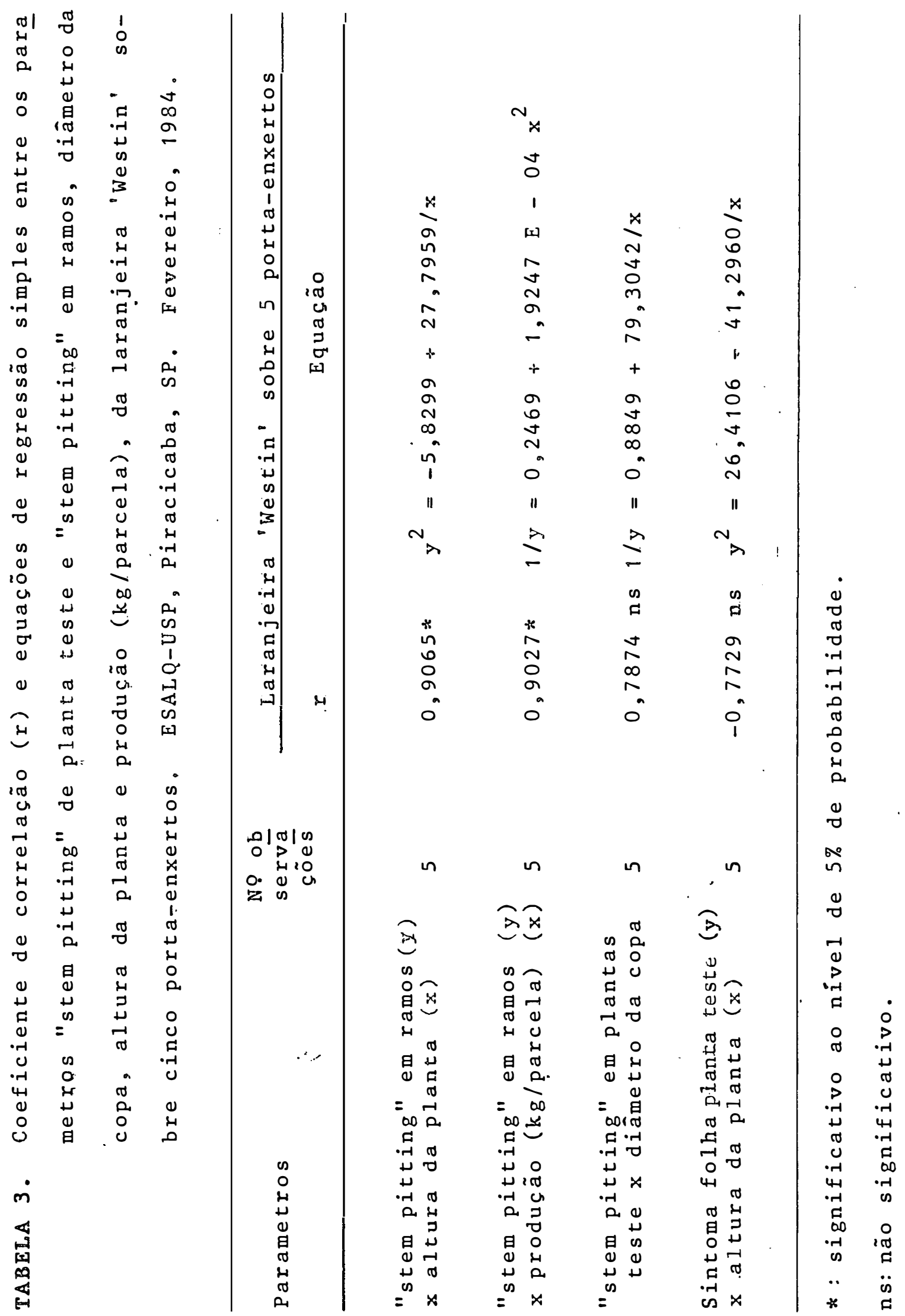




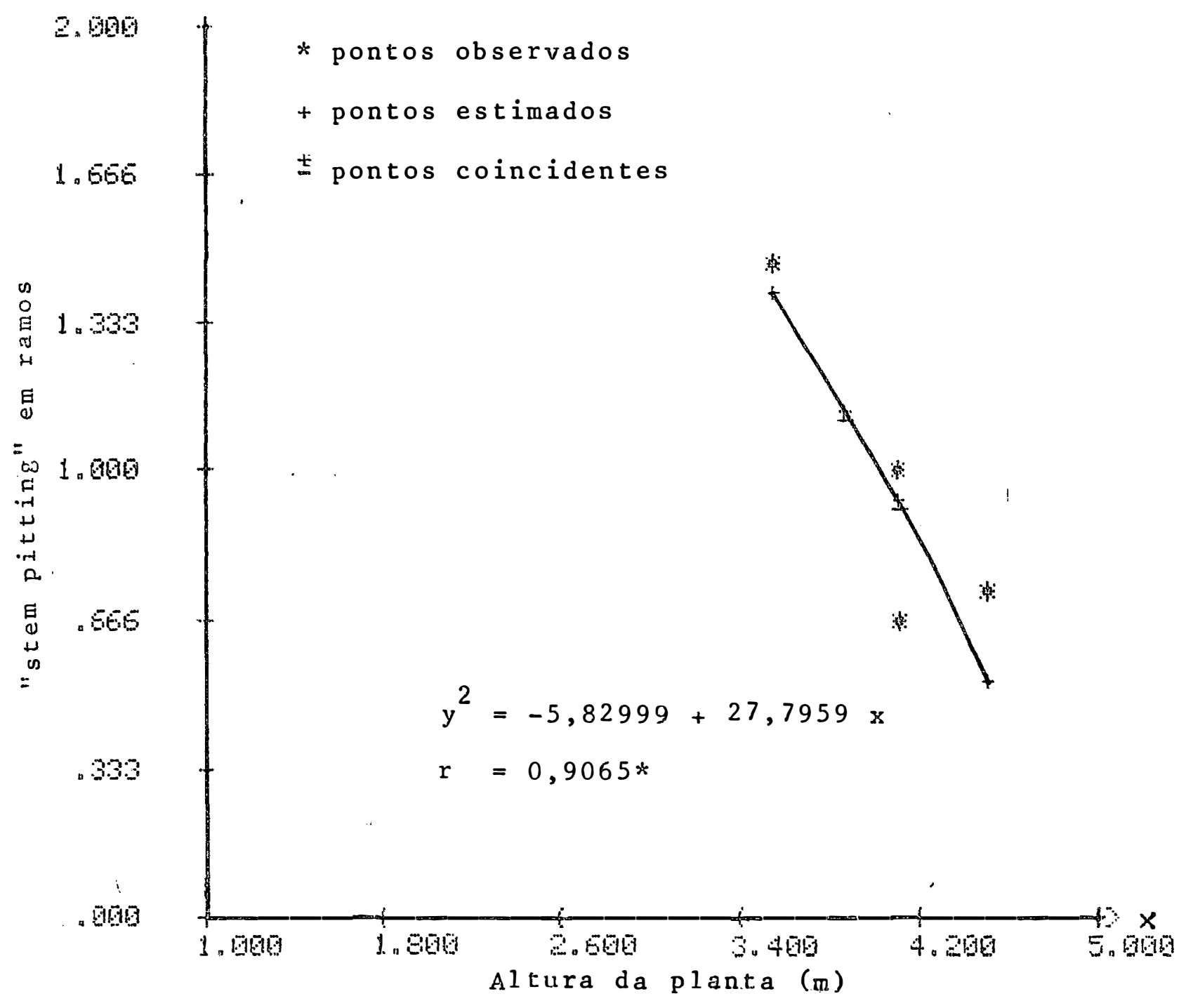

FIGURA 7. Equação de regressão entre o "stem pitting" em ramos e altura da planta da laranjeira 'Westin' sobre cinco porta-enxertos. ESALQ-USP, Piracicaba, SP. Fevereiro, 1984. 


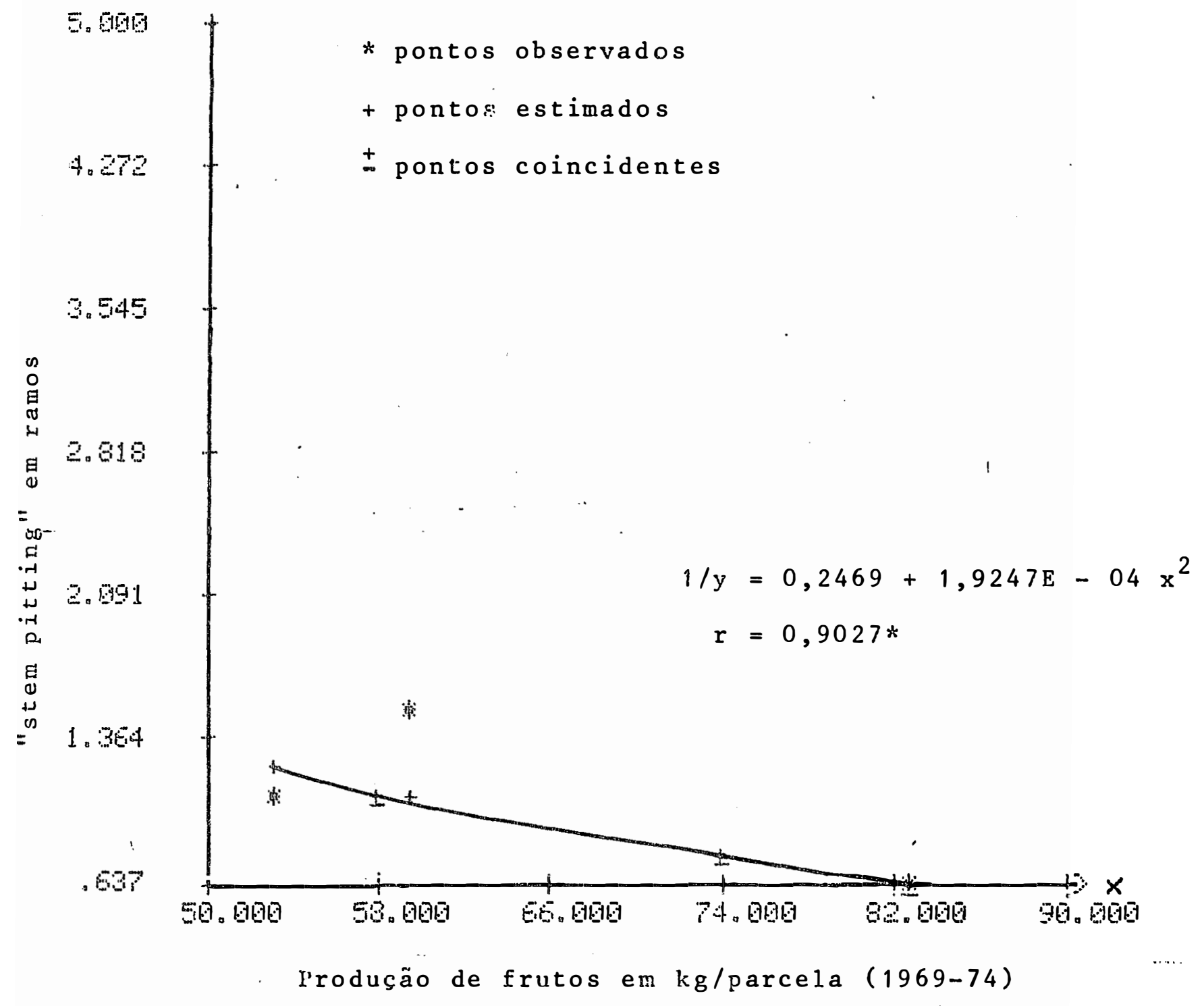

PIGURA 8. Equação dé regressão entre o "stem pitting" em ramos e produção de frucos em kg/parcela (1969-74) da laranjeira 'Westin' sobre cinco porta-enxertos. ESALQ-USP, Piracicaba, SP. Fe v̈ereiro, 1984. 


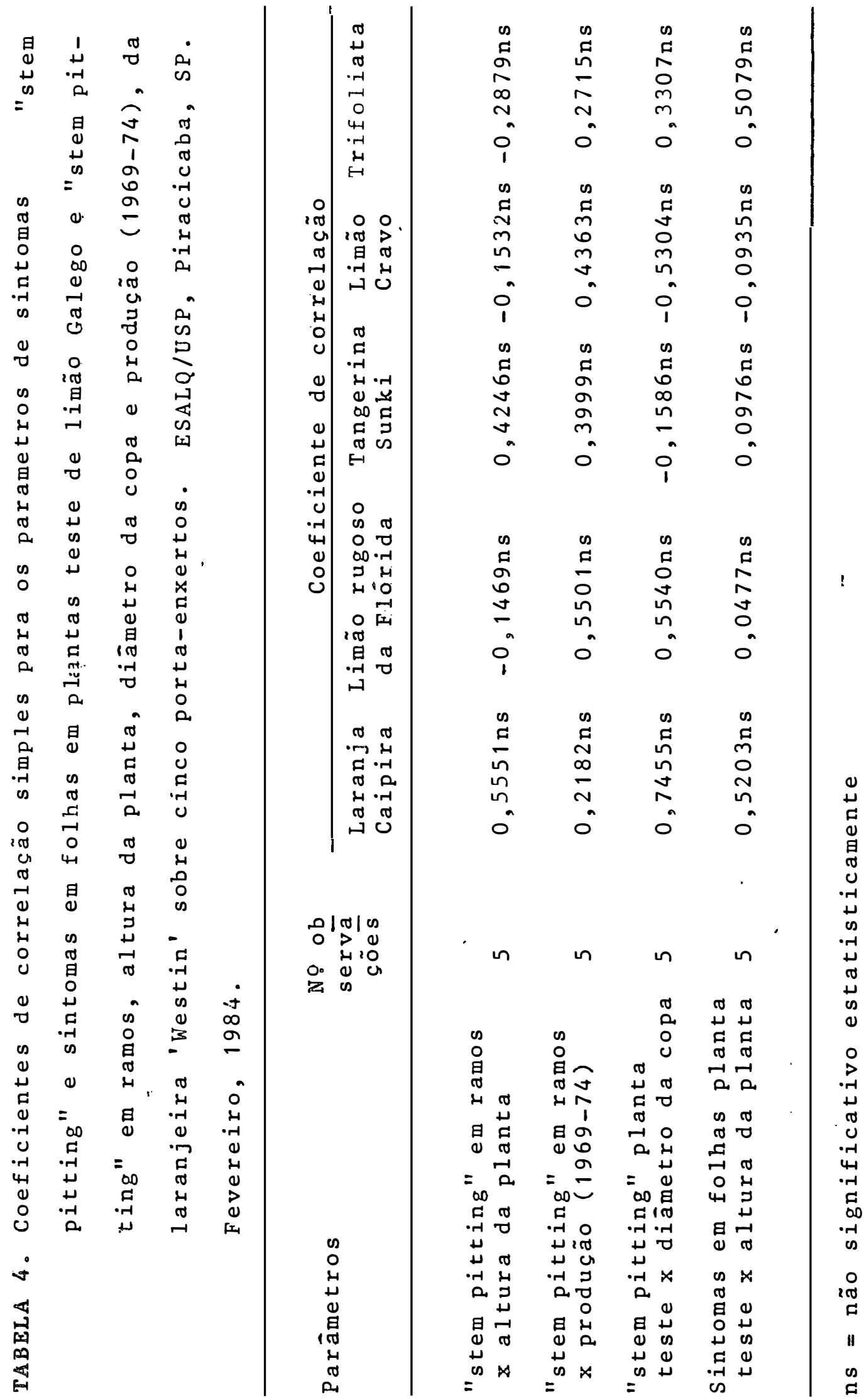


4.2. Avaliação de "stem pitting" na laranjeira 'Westin'

\subsubsection{Avaliaç̃̃o de "stem pitting" ou canelüras}

As notas da avaliaça dos sintomas referentes à "stem pitting" os ramos da copa da laranjeira 'Westin' são mostrados na Tabela 20, do Apēndice.

\subsubsection{Anālise estatística}

A anālise da variancia mostra que houve efeito altamente significativo na avaliação de "stem pitting" em ramos da copa, em função dos porta-enxertos utilizados para a laranjeira 'Westin' (Tabela 5).

Foi feito o estudo estatistico da variação da severidade de "stem pitting" na copa da laranjeira 'Westin', para verificar a influência dos porta-enxertos, comparando-se as médias pelo teste de Tuckey a $5 \%$ de probabilidade ( $\underline{\text { a }}$ bela 6). Evidenciou-se efeito dos porta-enxertos na variação das médias das notas dos sintomas de "stem pitting" na copa de laranjeira 'Westin'。O gräfico barras representativas das médias é mostrado na Figura 19 do Apēndice. 
.58.

TABELA 5. Anälise da variāncia dos dados médios referentes as notas dos testes de Tristeza em ramos da laran jeira 'Westin' sobre cinco porta-enxertos. ESALQUSP, Piracicaba, fevereiro de 1984 .

$\begin{array}{llll}\text { Causa da variação G.L. } & \text { Q.M. } & \text { F }\end{array}$

$\begin{array}{lllr}\text { Blocos } & 5 & 0,0973 & 1,64 \mathrm{~ns} \\ \text { Tratamento } & 4 & 0,6529 & 1 \\ & & & 11,01 * *\end{array}$

Residuo

$20 \quad 0,0592$

Tota 1

29

C. V. (\%) $\quad 24,46$

ns: não significativo

**: a 1 tamente significalivo

CV: Coeficiente de Variação 


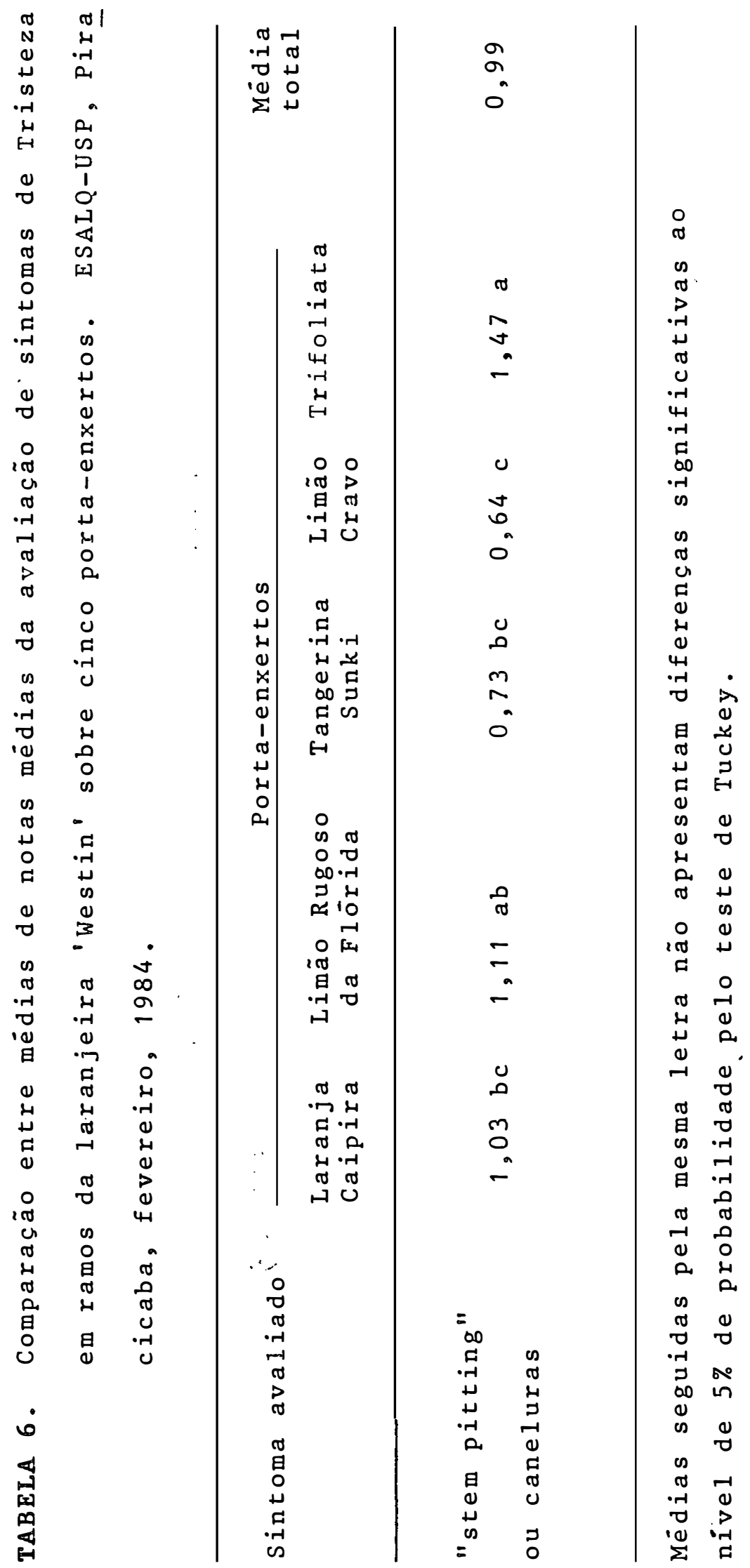



tronco (cm), diâmetro da copa (m), altura da planta (m), àrea produtiva e indice de conformação (A/D) da laranjeira 'Westin' sobre os cinco diferentes porta-enxertos são apresentados nas Tabelas 21 a 25 , do Apēndice.

\subsubsection{Anālise estatîstica}

Foi feita a añ lise da variāncia dos parâme-tros do vigor: circunferēncia do tronco (m), diāmetro da copa (m), altura mëdia da planta, àrea produtiva e indice de conformação, conforme mostra a Tabela 7 .

Verifica-se na mesma, que para os parāmetros: circunferéncia do tronco (cm), diāmetro da copa (m), altura média da planta (m), e àrea produtiva $\left(\mathrm{m}^{2}\right)$, houve diferença significativa entre os diferentes porta-enxertos ao nivel de 1\% de probabilidade. Porém, para o parámetro índice de conformação houve diferença significativa entre porta-enxerto ao nivel de $5 \%$ de probabilidade.

Nos estudos de significāncias dos valores do teste F, conforme mostra a mesma Tabela 7, a anälise estatís tica encontrou efeitos estatisticos significativoside blocos nos 
.61.

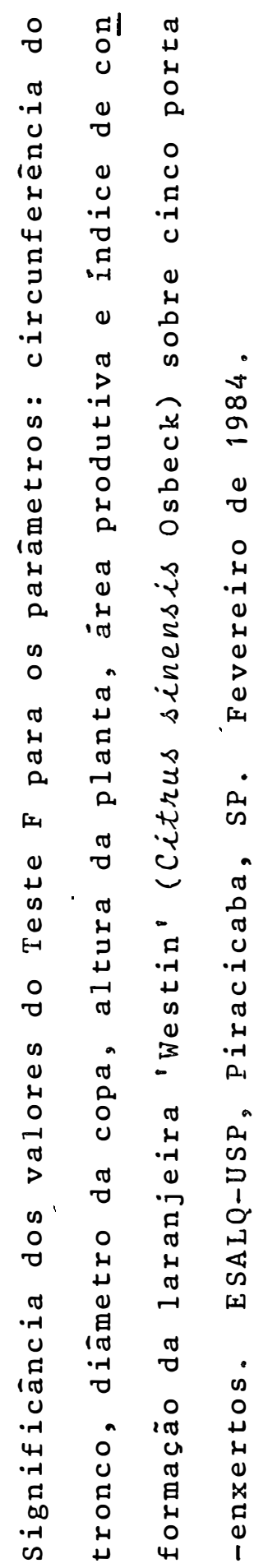

ขึ

告合

ป

- $\rightarrow$ 出

모

in 0

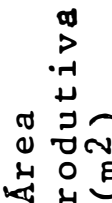

a

$\begin{array}{ll}\infty & * \\ \sim & \text { in } \\ \sim & m\end{array}$

$\stackrel{n}{\sim}$

敢

先西

《珀

$\begin{array}{ll}* & * \\ \stackrel{*}{N} & \stackrel{*}{N} \\ \stackrel{N}{N}\end{array}$

$\underset{\sigma}{\infty}$

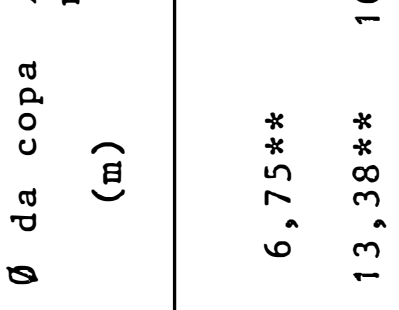

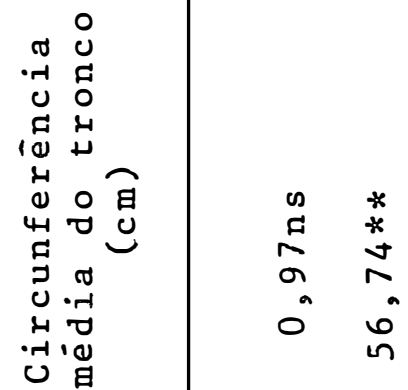

0
$\infty$
6

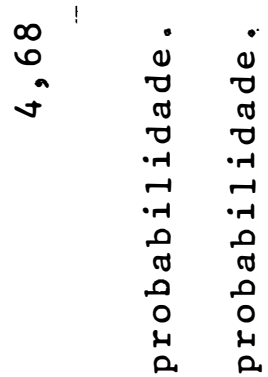

$\begin{array}{lll}\infty & 0 & 0 \\ \sim & 0 & 0\end{array}$

nं in 은

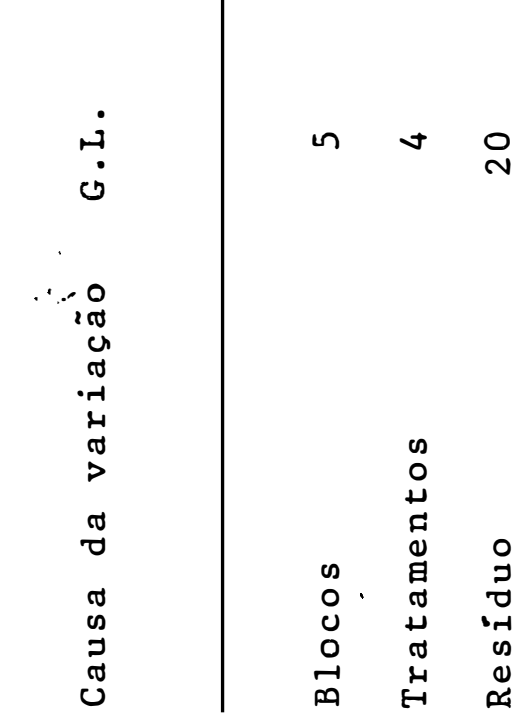

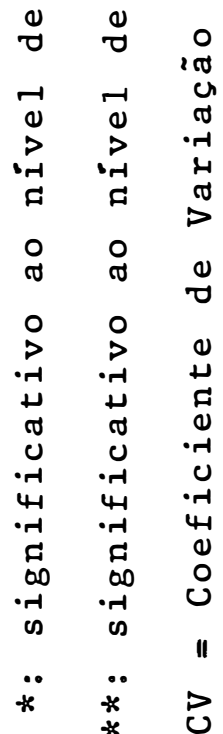


parāmetros: diāmetro da copa e àrea produtiva, embora resultaram com valores do coeficiente de variação baixos, segundo PIMENTEL GOMES (1981).

As comparações entre médias pelo teste de Tuckey a $5 \%$ de probabilidade, são mostradas na Tabela 8 . Na Figura 20 do Apēndice são apresentados os gräficos de barras das médias. 0 teste $F$ evidenciou efeito dos porta-enxertos na variação das médias dos diferentes parāmetros físicos do vigor na laranjeira 'Westin'.

Na Tabela 9 mostram-se os modelos de regressão simples obtidos, segundo o programa CURVAS, para os para metros: circunferéncia do tronco, diāmetro da copa, altura da planta, ärea produtiva e indice de conformação. Na anäli se de regressão simples, representados na mesma Tabela, veri fica-se correlaçào signiticativa ao nivel de $1 \%$ de probabili dade entre os paràmetros: circunferéncia do tronco e diàmetro da copa; circunferéncia do tronco e àrea produtiva e, diâmetro da copa e àrea produtiva. Houve corrélação signif cativa para os parâmetros: circunferência do tronco e altura da planta, ao nivel de $5 \%$ de probabilidade, e, não houve diferença estatisticamente significativas para os parametros altura de planta e àrea produtiva; e, entre a altura da plan ta e indice de conformação. As Figuras 9 a 12 , referem-se às equações de regressão entre o parāmetro circunferência do tronco e os parāmetros diāmetro da copa, altura da planta e 


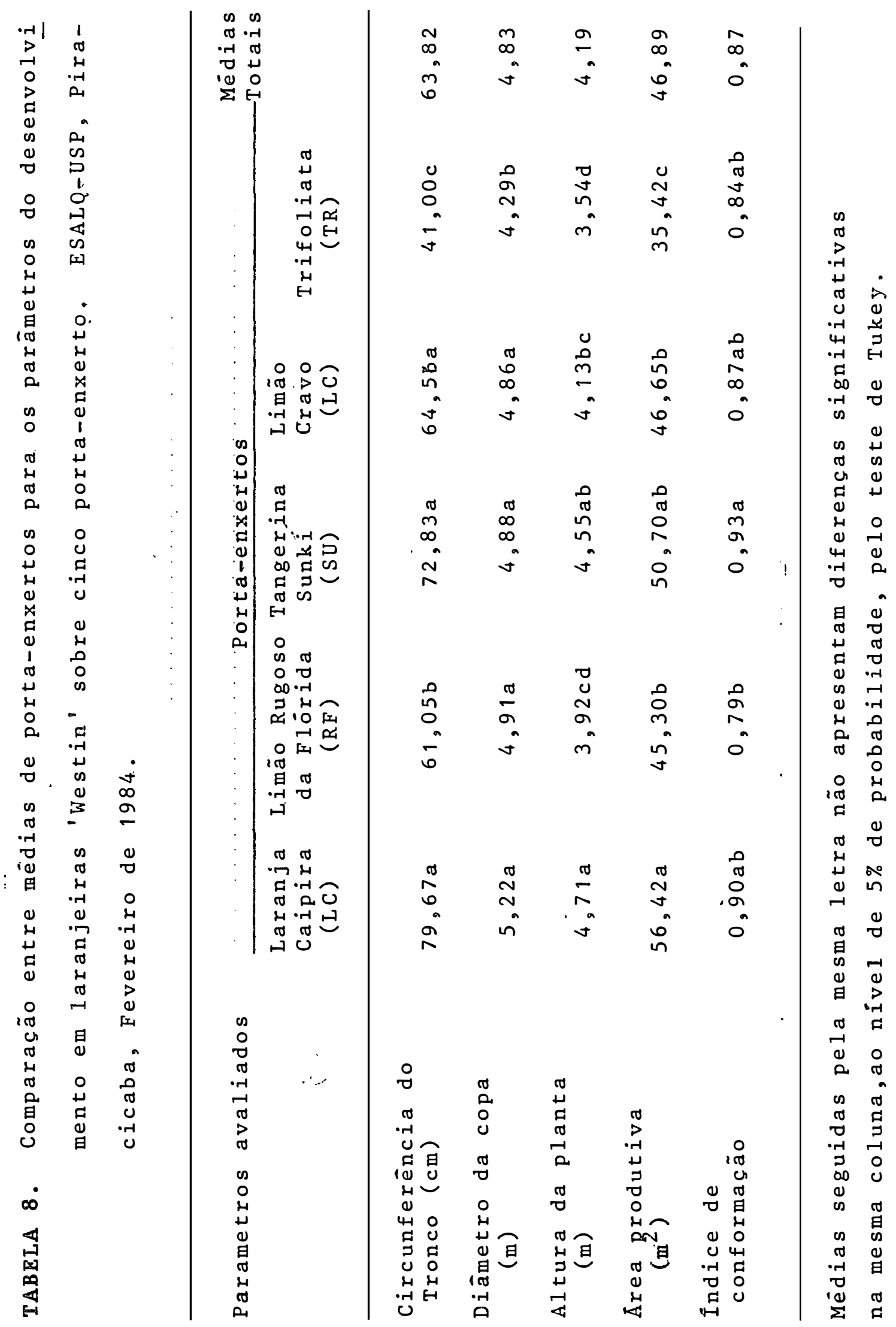


.64.
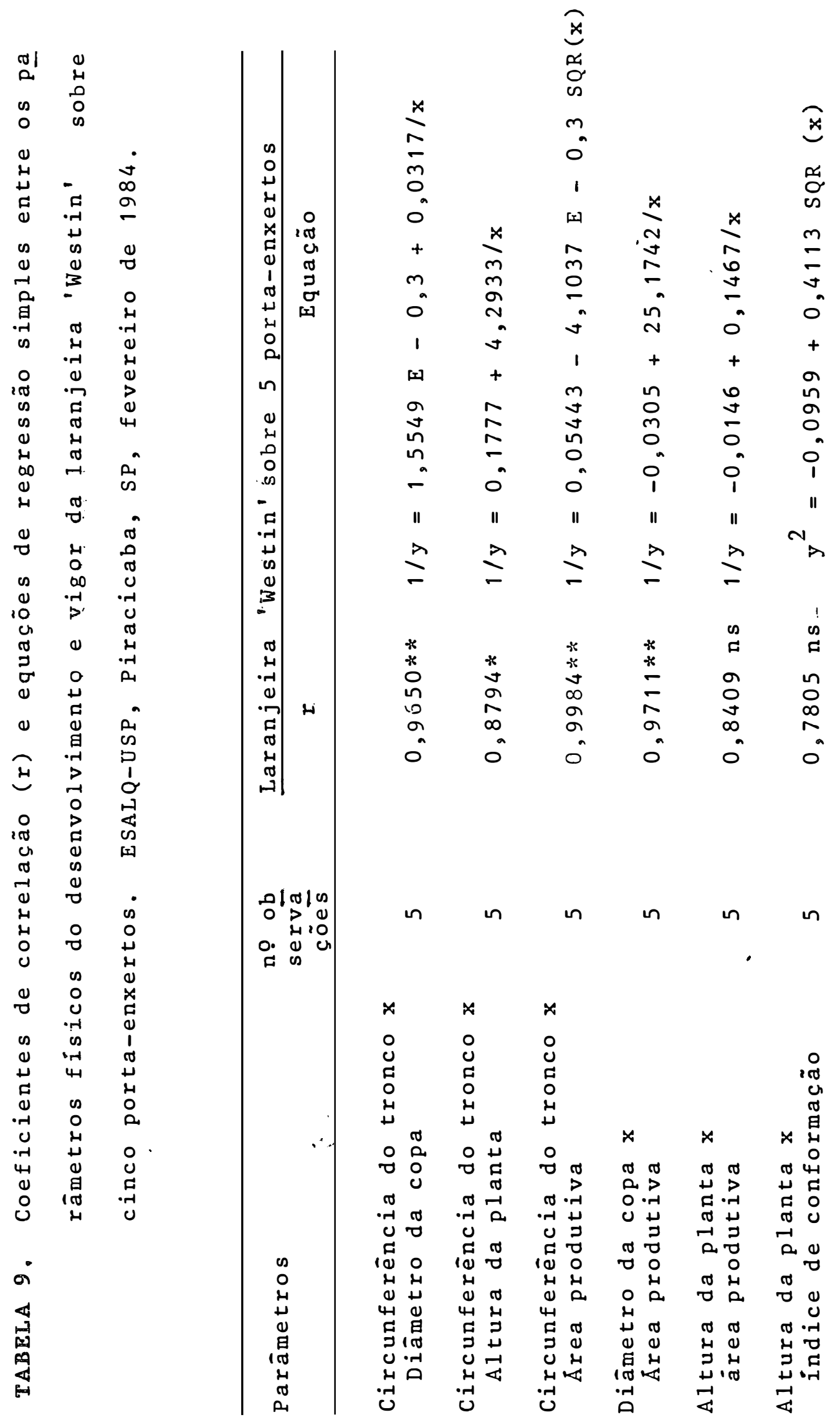

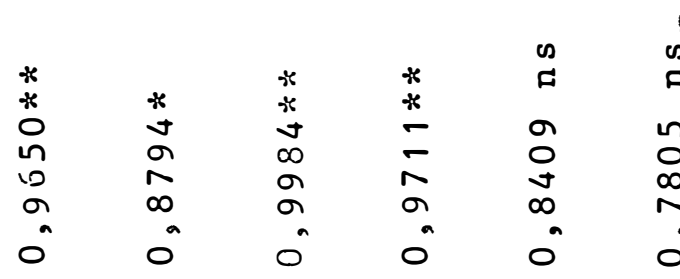

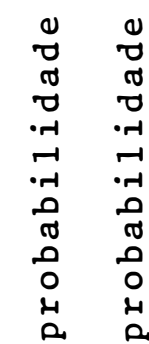

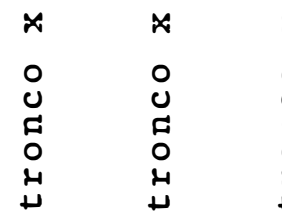

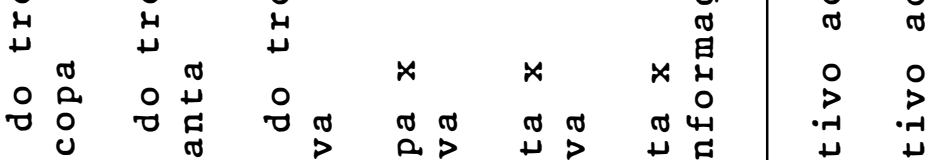

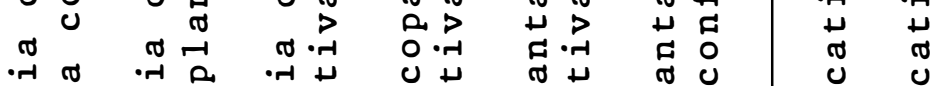
ठ

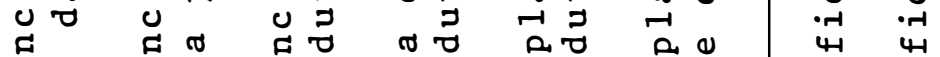

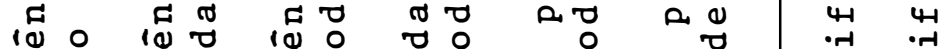

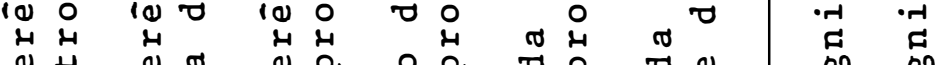

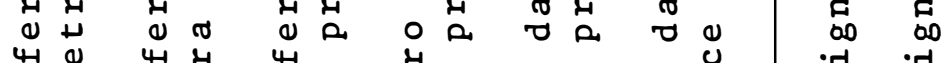

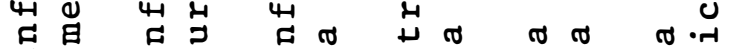
$\exists(0)$ 更 ป.

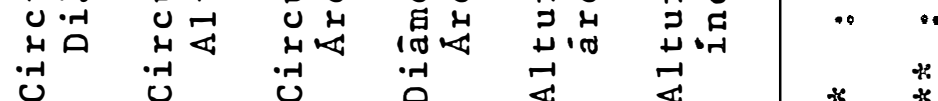




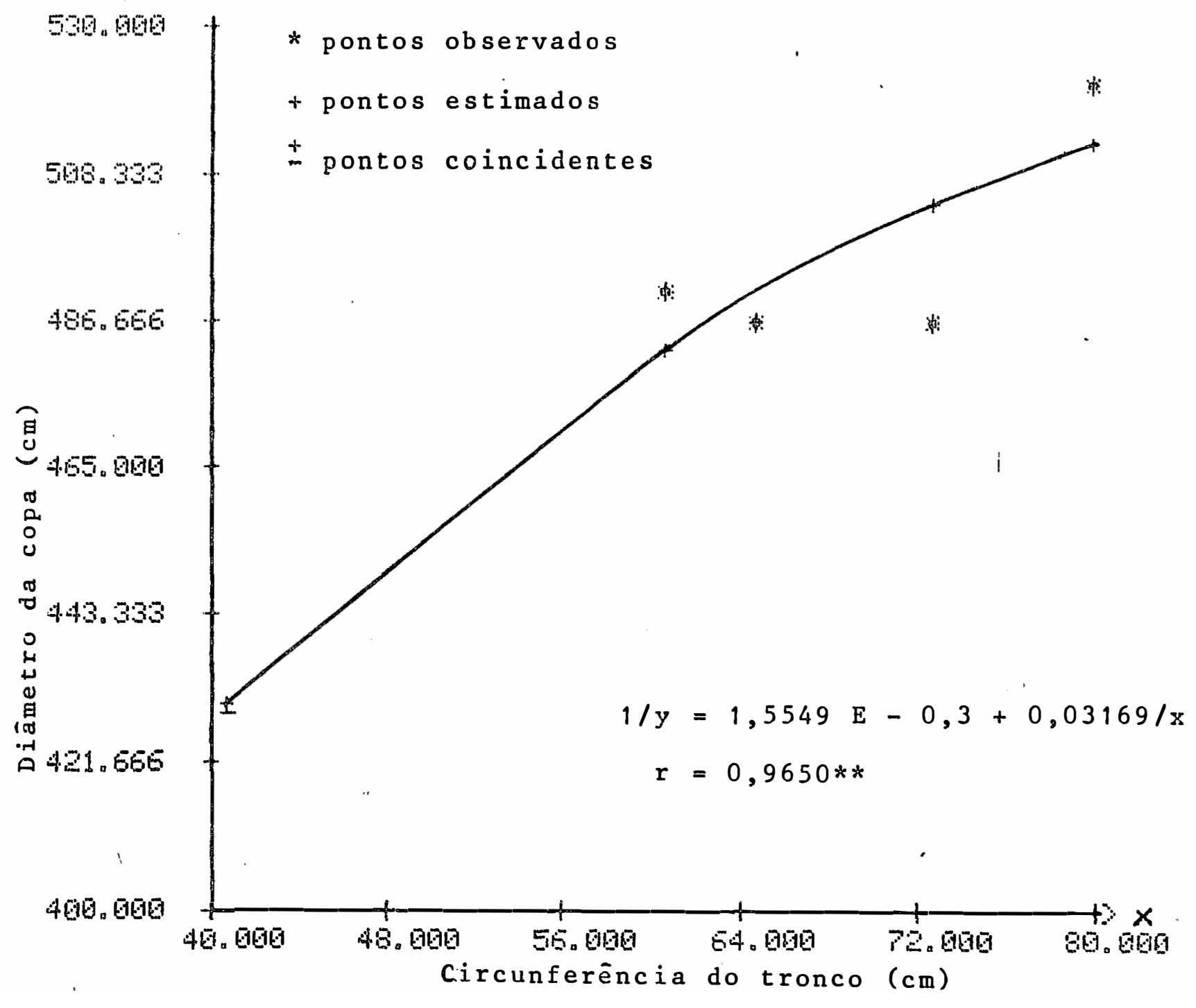

FIGURA 9. Equação de regressão entre a circunferência do tronco ( $\mathrm{cm}$ ) e diâmetro da copa ( $\mathrm{cm}$ ) da laranjeira 'Westin' sobre cinco porta-enxertos. ESALQ-USP, Piracicaba, SP. Fevereiro, 1984. 


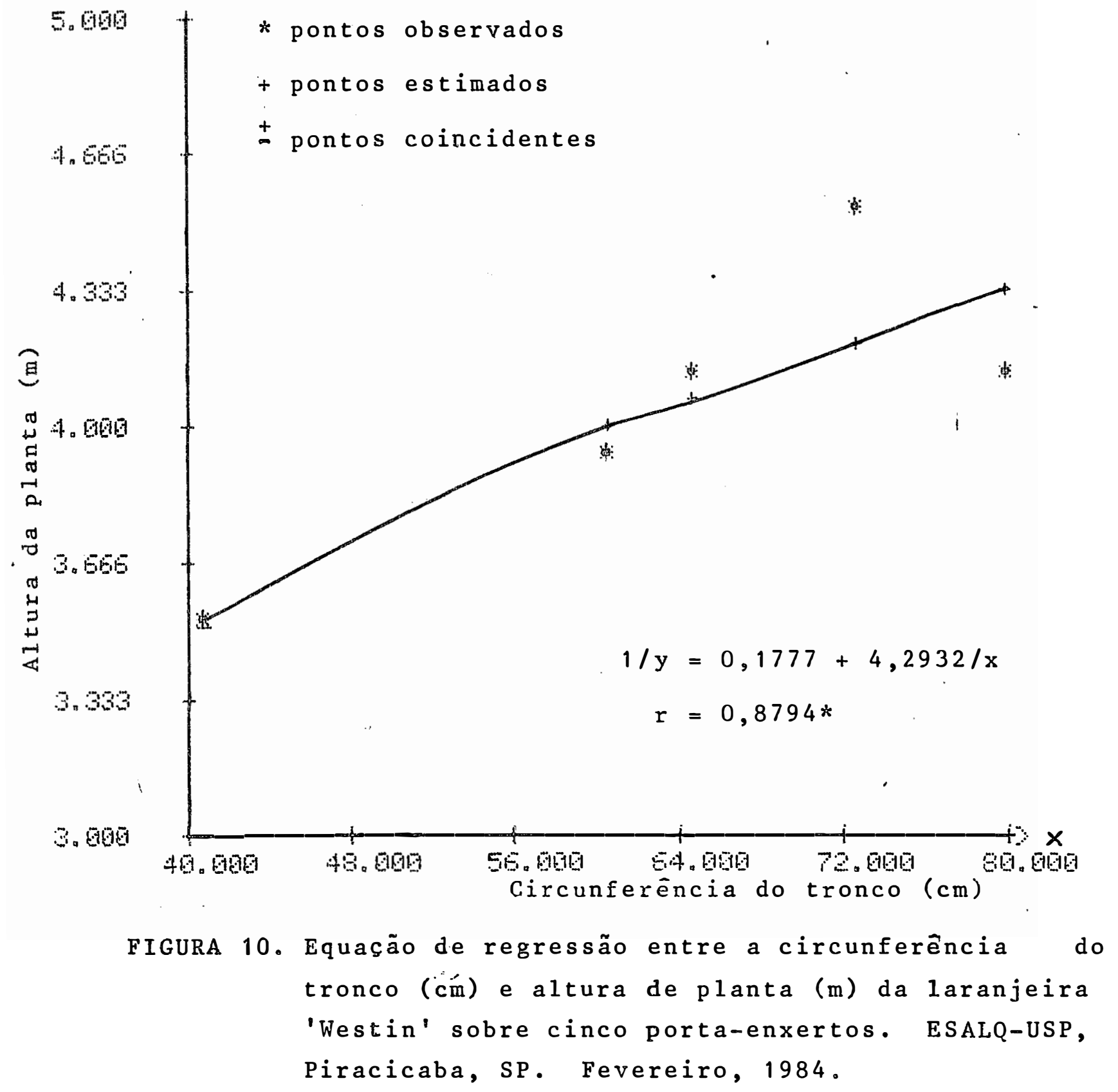




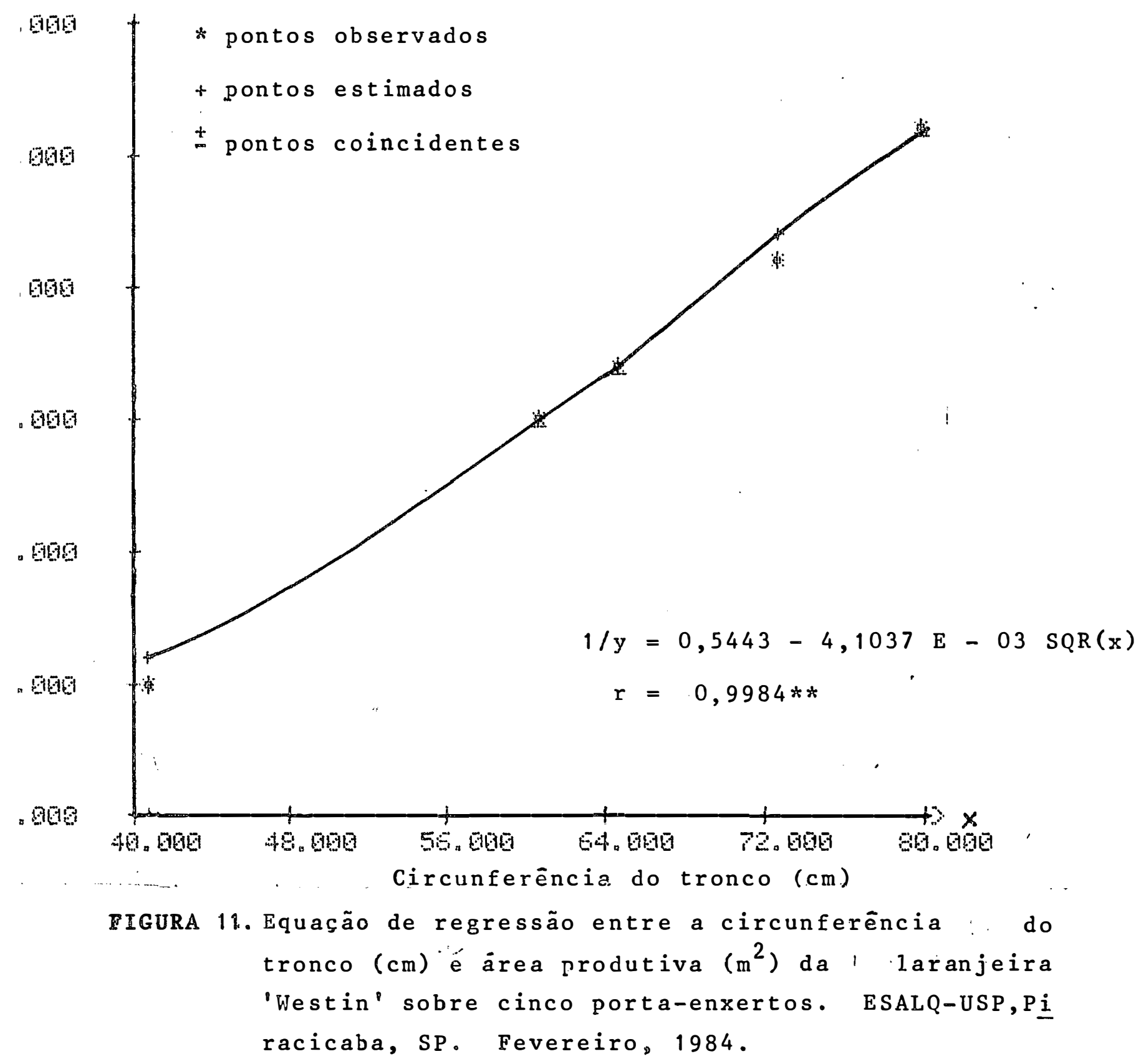




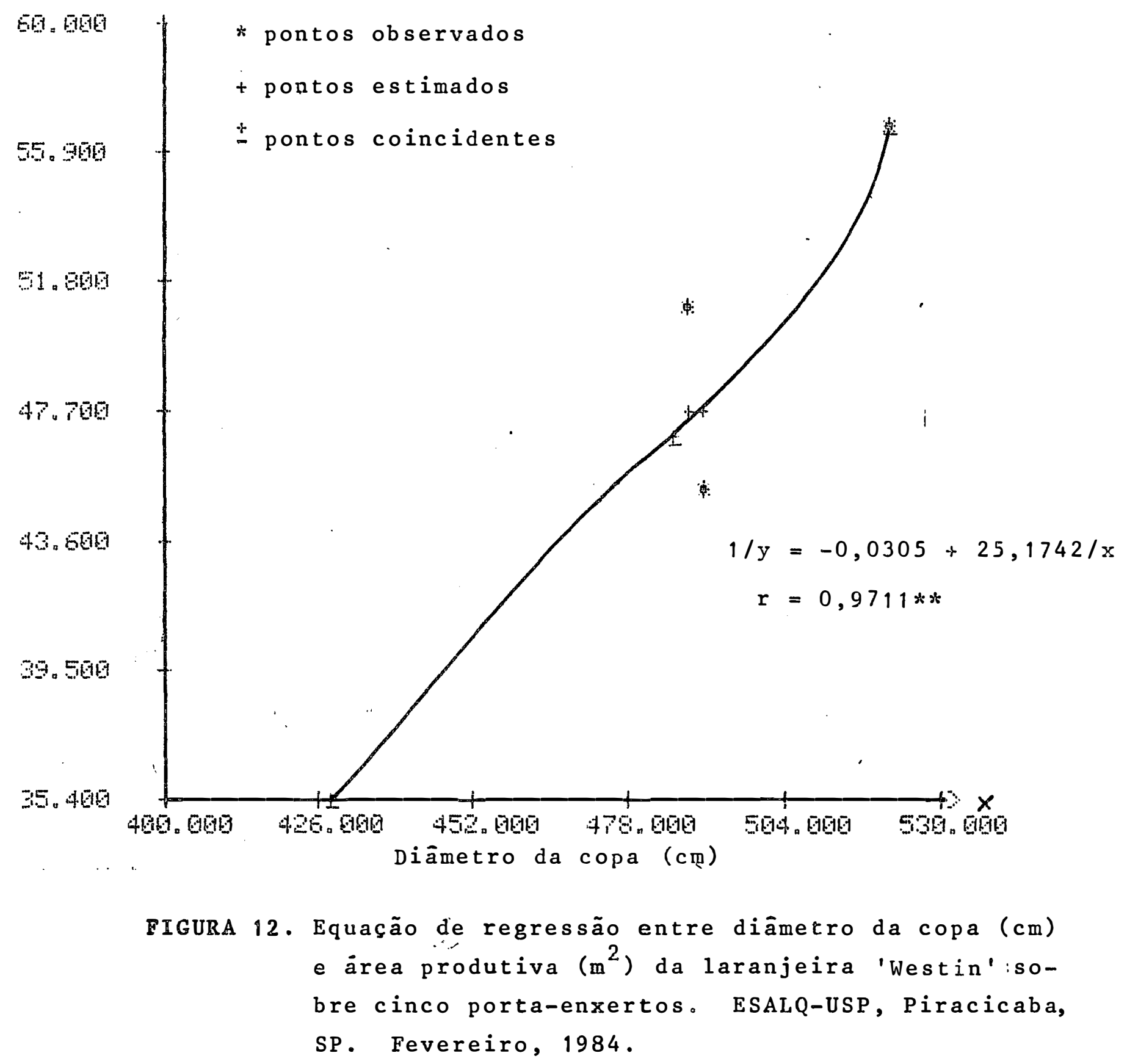


ărea produtiva, é, o diâmetro da copa e ärea produtiva, na laranjeira 'Westin' sobre os diferentes porta-enxertos estudados.

\subsection{Produção}

4.4.1. Dados de producão

Os dados de produção das plantas, expressos em quilogramas de fruta por parcela, da laranjeira 'Westin' sobre os diferentes porta-enxertos, nos anos de 1969 a 1974 são apresentados na Tabela 26 do Apēndice.

As produções médias expressadas em nümero de frutos por parcela e nümero de caixas por parcela, da laranjeira 'Westin'e os cinco diferentes porta-enxertos, são mostradas nas Tabelas 27 e 28 do Apēndice.

\subsubsection{Anālise estatistica}

A añalise de variancia dos dados de produçós médias e valores dos coeficientes de variação da laranjeira 'Westin' sobre os diferentes porta-enxertos na ärea de Lajea do nos anos de 1969 a 1974 émostrada na Tabela 10. Como se pode verificar na mesma, houve diferença significativa aos niveis de $1 \%$ de probabilidade, pelo teste F, respectiva- 
TABELA 10. Significância dos valores do teste F para os parâ metros: produção média (1969-74), produção em número de frutos/parcela (1980-82) e número de caixas/parcela (1980-82) da laranjeira 'Westin' sobre cinco porta-enxertos. ESALQ-USP, Piracicaba, SP. Fevereiro 1984 .

\begin{tabular}{|c|c|c|c|c|}
\hline \multirow{2}{*}{ Causa da variação } & \multirow{2}{*}{ G.L. } & \multicolumn{3}{|c|}{$\mathrm{F}$} \\
\hline & & $\begin{array}{r}\text { Produção } \\
(1969-74)\end{array}$ & $\begin{array}{l}\text { No frutos } \\
(1980-82)\end{array}$ & $\begin{array}{l}\text { No caixas/ } \\
\text { parcela } \\
(1980-82)\end{array}$ \\
\hline
\end{tabular}

Blocos $\quad 5 \quad 1,17 n s \quad 2,73 n s \quad$ : 2,26ns

Tratamentos $\quad 4 \quad 13,66 * * \quad 1,09 \mathrm{~ns} \quad 8,11 * *$

Residuos 20

Total 29

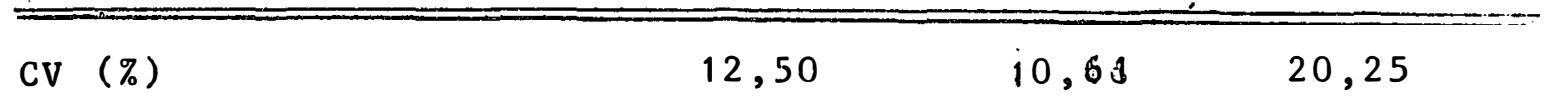

* * signficativo ao nivel de $1 \%$ de probabilidade. ns: não significatívo

CV: Coeficiente de Variação 


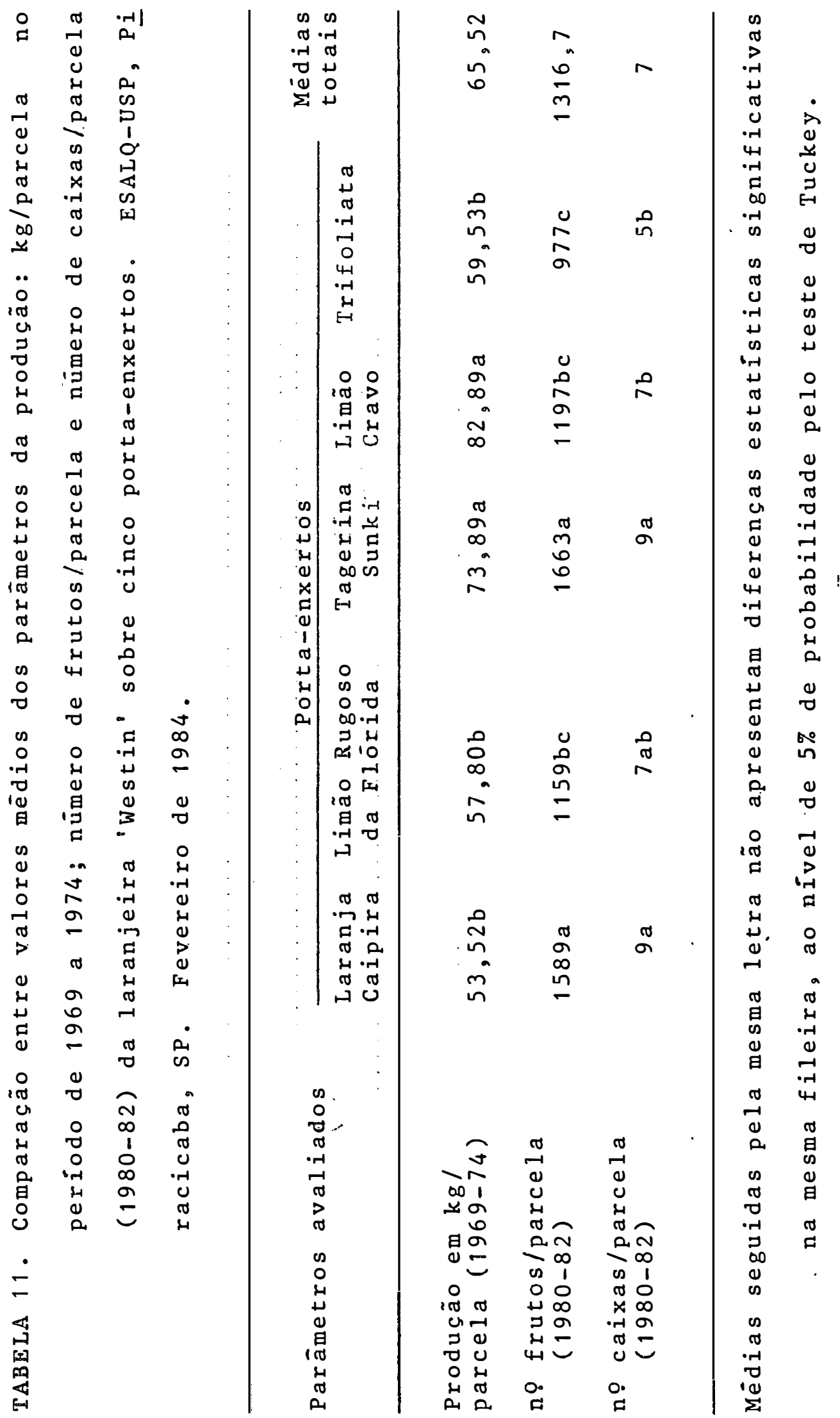


mente para produção dos anos 1969-74 (kg/parcela) e número de caixas/parcela nos anos 1980-82, enquanto que para a pro dução em nümero de frutos/parcela nos anos de 1980-82, verificou-se a não existēncia de significāncia para os valores de F.

Os estudos dos contrastes entre médias de por ta-enxertos pelo teste de Tuckey (Tabela 11), para os parâme tros de produção da laranjeira 'WEstin', acusaram diferenças estatisticamente significativas ao nivel de $5 \%$ de probabilidade entre médias estudadas.

Na Tabela 12 acharise os resultados da seleção dos modelos de regressão simples entre os parāmetro produção em caixas de frutos/parcela (1980-82), e os diferentes parāmetros estudados. As Figuras 13 a 16 referem-se as correlações significativas entre o parāmetro da produção estudado e os diferentes parāmetros do vigor.

Verificou-se correlações significativas e negativas ao nivel de $1 \%$ de probabilidade entre os parametros número de caixas de frutos/parcela e circunferéncia do tron co (m). As correlações entre o parāmetro nümero de caixas de frutos/parcela e os parametros diámetro da copa (m), altu ra de planta (m) e ärea produtiva resularam ser significativos ao nivel de $5 \%$ de probabilidade. 


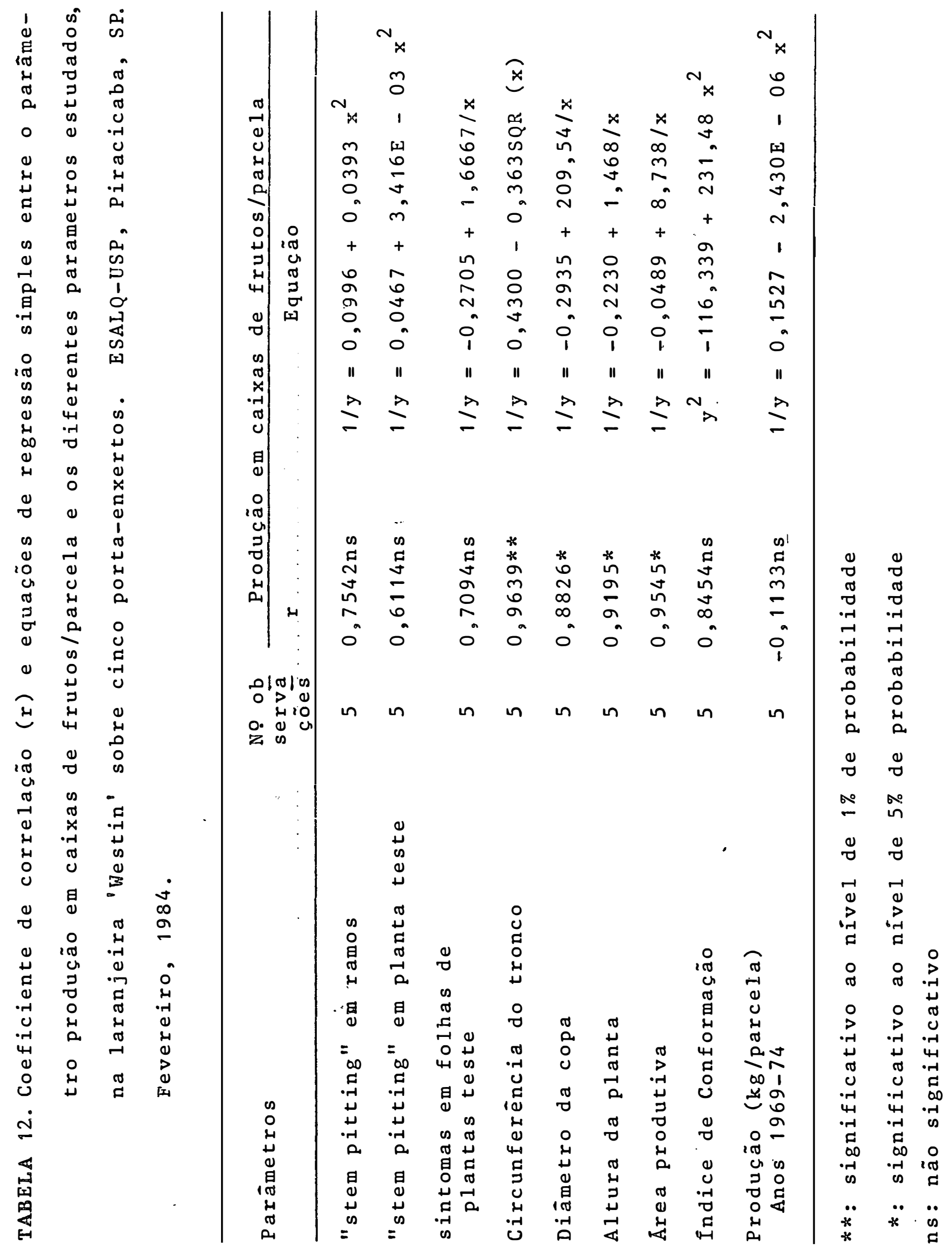




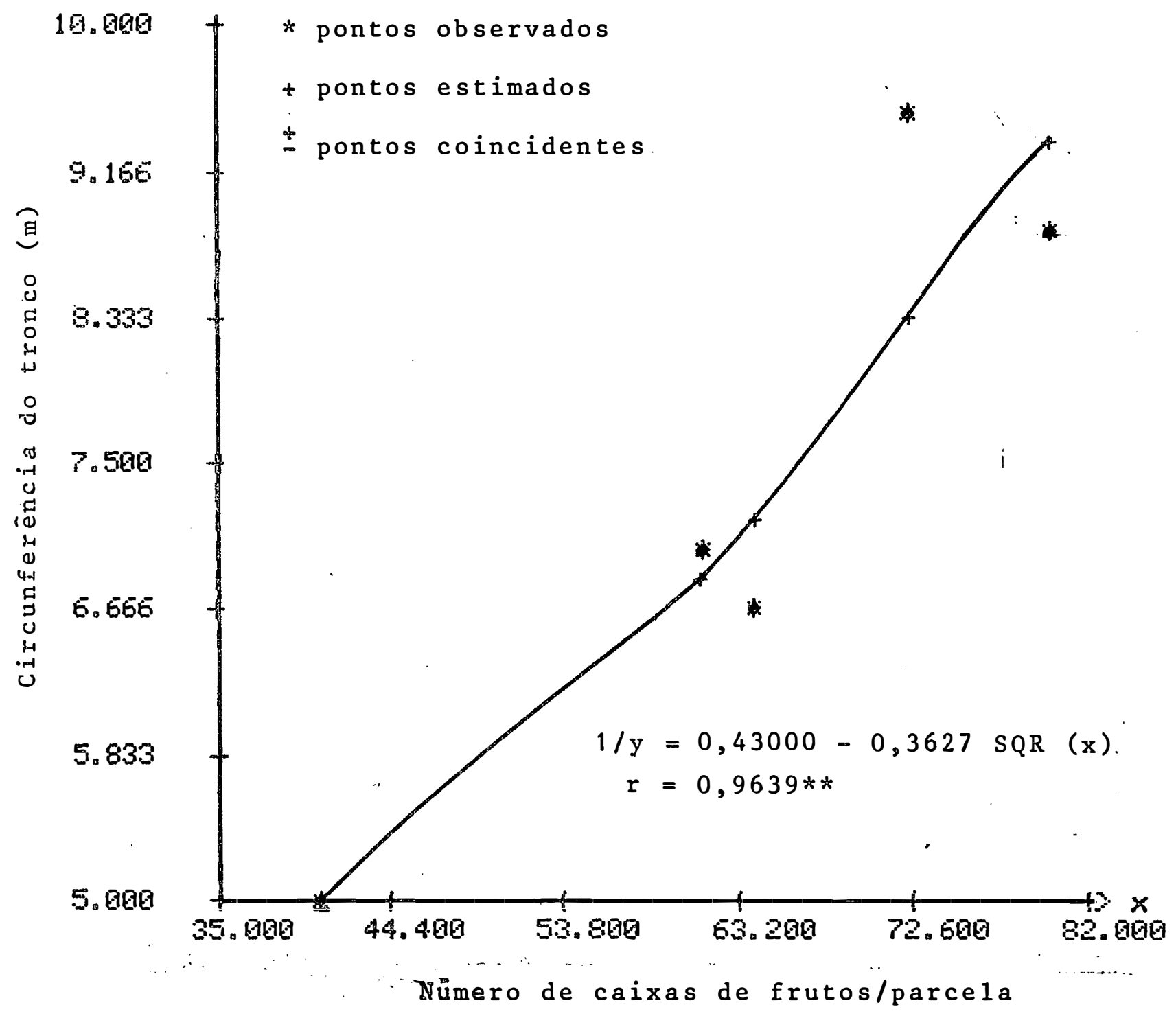

FIGURA 13. Equação de regressão entre o nümero de caixas de frutos/parcela e circunferência do tronco (m) na laranjeira 'Westin' sobre cinco porta-enxertos ESALQ-USP, Piracicaba, SP. Fevereiro, 1984. 


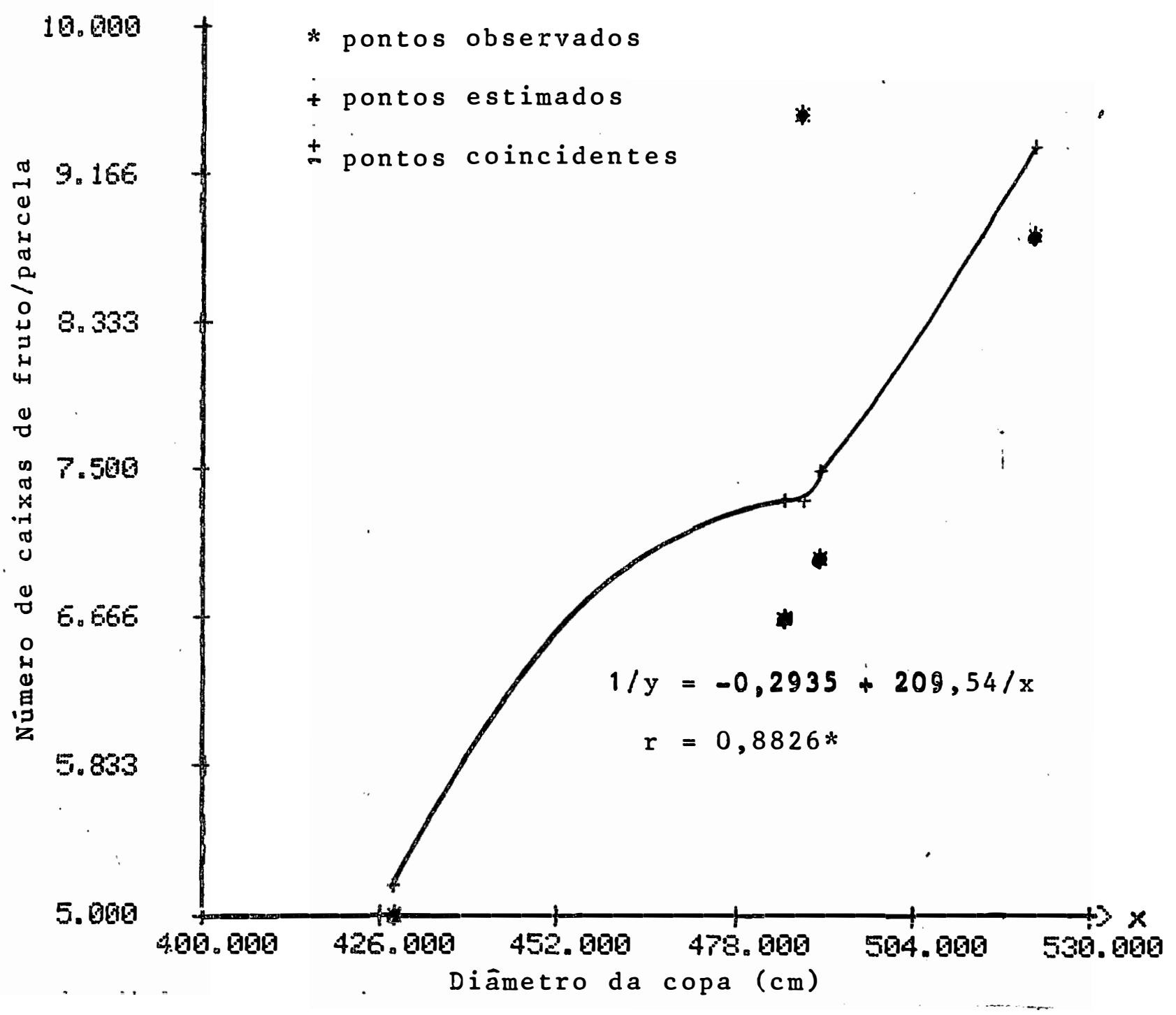

FIGURA 14. Equação dè regressão entre o nümero de caixas de frutos/parcela e o diâmetro da copa na laranjeira 'Westin' sobre cinco porta-enxertos (cm). ESALQUSP, Piracicaba, SP. Fevereiro, 1984. 
.76 .

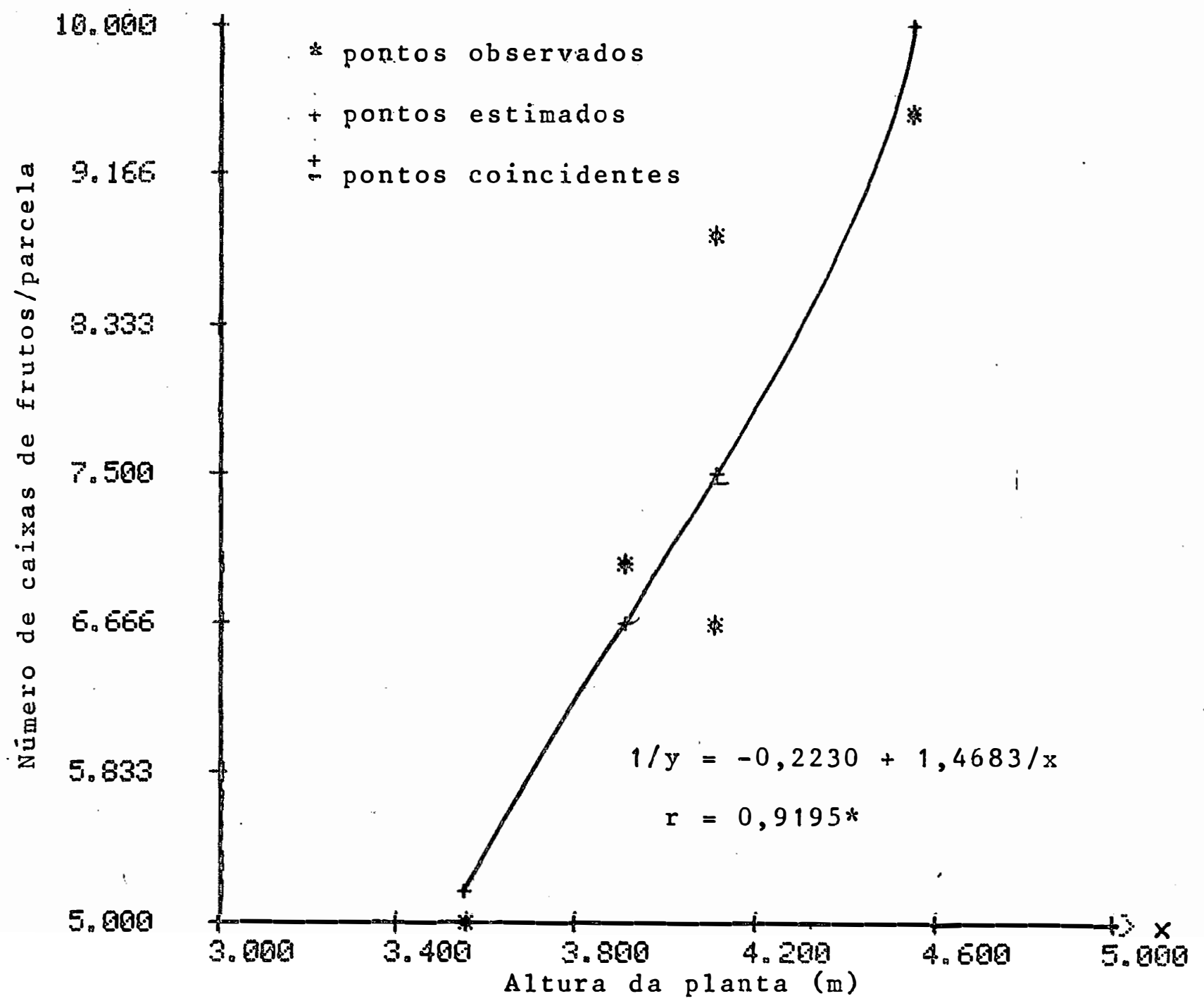

FIGURA 15. Equação de regressão entre o nümero de caixas de frutos/parcela e a altura da planta na laranjeira 'Westin' sobre cinco porta-enxertos. ESALQ-USP,P追 racicaba. Fevereiro, 1984 . 


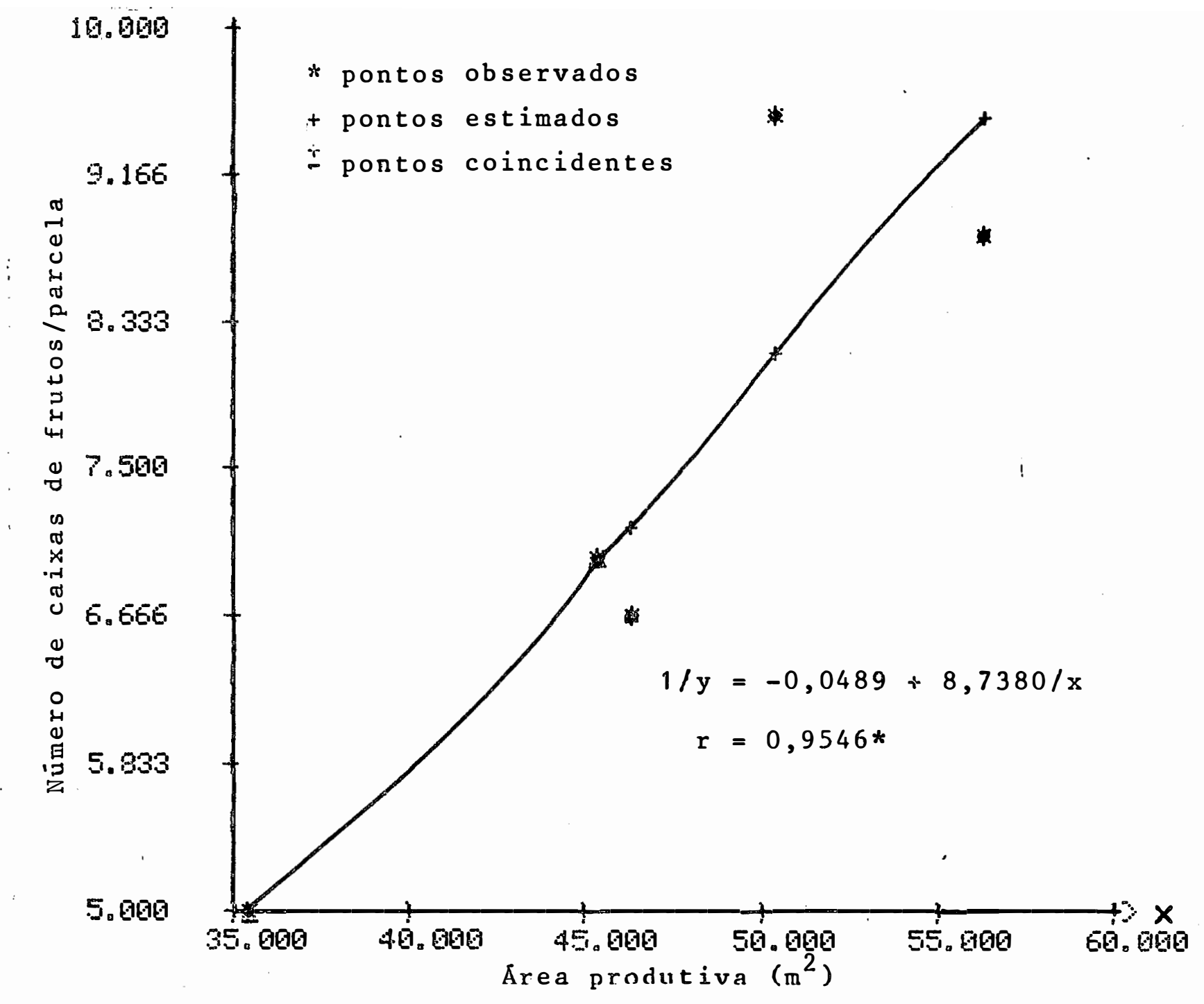

FIGURA 16. Equação de regressão entre o número de caixas de frutos/parcela e ärea produtiva da laranjeira 'Wes tin' sobre cinco porta-enxertos. ESALQ-USP, Piracicaba, SP. Fevereiro, 1984 . 
4.6. Seleção de grupos similares de laranja 'Westin' sobre cinco porta-enxertos

A anälise dos Componentes Principais indicou no espaço euclidiano tridimensional, 4 grupos distintos de combinações de laranjeira 'Westin' sobre porta-enxertos (Figura 17), levando-se em consideração 9 características relacionadas com os paràmetros: sintomas de Tristeza, vigor e produção.

A mesma anàlise indicou quais os parâmetros que mais influenciaram na formaça desses grupos (vide Figura 17). Essa anälise foi utilizada como complementação da Anälise de Agrupamento, devido ao fato de que para essa não existe teste estatistico de hipötese.

Como resultado da Anälise de Agrupamento obte ve.se uma gräfica hierärquica denominado Fenograma (Figura 18 ), onde a uma distância de afinidade (Euclidiana média) = $=0,6$ se obteve 4 grupos distintos. 
.79.

\begin{tabular}{lrrr}
\hline Porta-enxertos & \multicolumn{3}{c}{ Eixos ortogonais } \\
\cline { 3 - 5 } & \multicolumn{1}{c}{$\mathrm{x}$} & \multicolumn{1}{c}{$\mathrm{y}$} & $\mathrm{2}$ \\
\hline Laranjeira Caipira (CA) & 1,428 & $-1,485$ & 1,677 \\
Tangerineira Sunky (SU) & $-0,222$ & $-1,474$ & 4,470 \\
Limão Cravo (LC) & 2,007 & 1,363 & 2,644 \\
Limoeiro Rugoso da Flörida (RF) & 0,638 & 1,158 & 3,830 \\
Trifoliata (TR) & $-3,850$ & 0,437 & 2,376 \\
\hline Coeficiente de explicaçao (\%) & 59,3 & 21,59 & 14,22 \\
\hline
\end{tabular}

Escala $(x, y, z)$
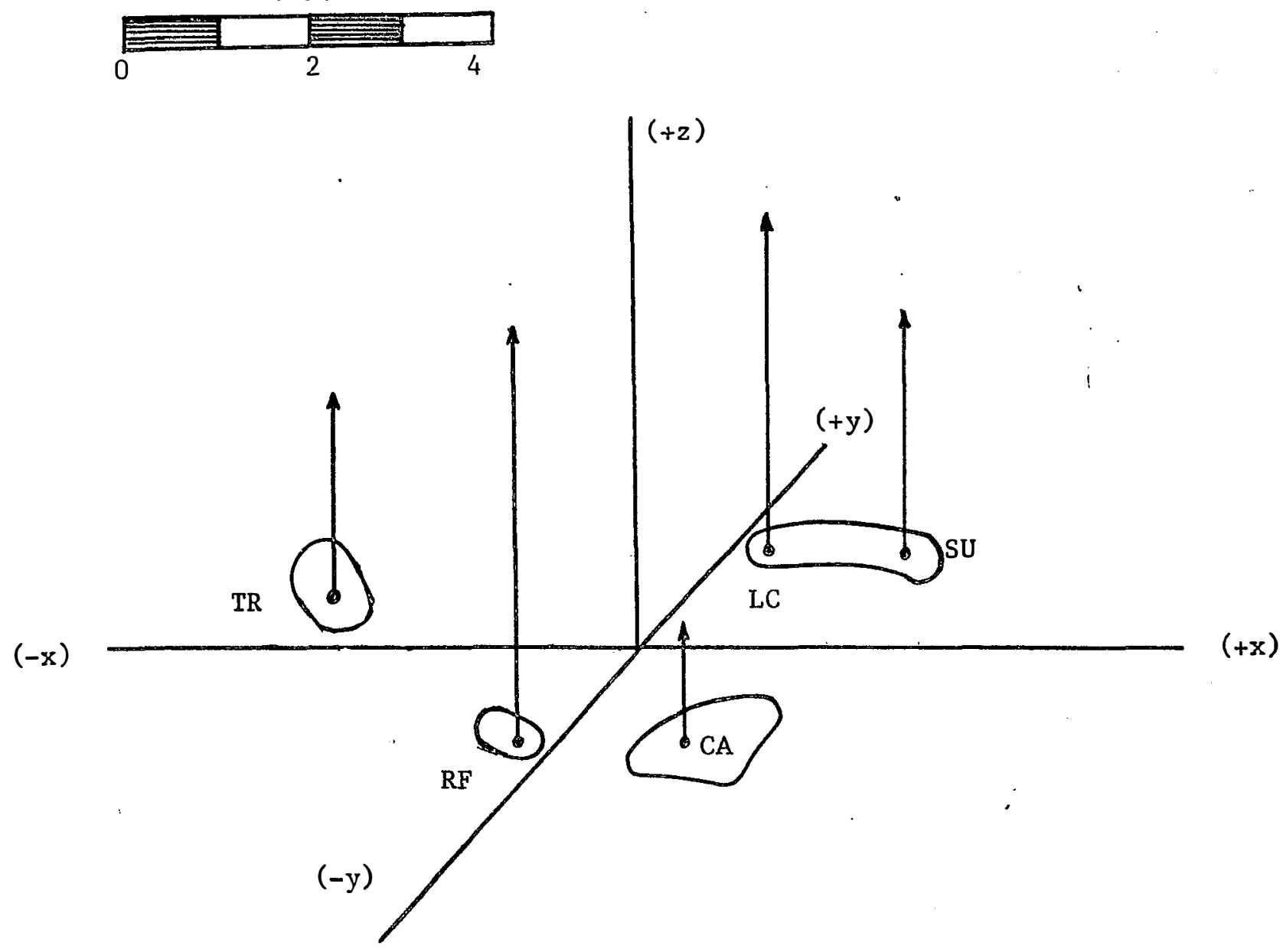

FIGURA 17. Diagrama tridimensional comparativo de porta-enxertos para a Laranjeira 'Westin', em função dos sintomas de Tristeza ("stem pitting" em ramos e planta teste), vi gor e produção, pelo método de Anàlise de Componentes Principais e Agrupamentos. 
.80 .

\begin{tabular}{l} 
Porta-enxertos \\
\hline CA $=$ Laranjeira Caipira \\
SU = Tangerineira Sunky \\
LC $=$ Limoeiro Cravo \\
RF $=$ Limoeiro Rugoso da Flórida \\
TR $=$ Trifoliata
\end{tabular}

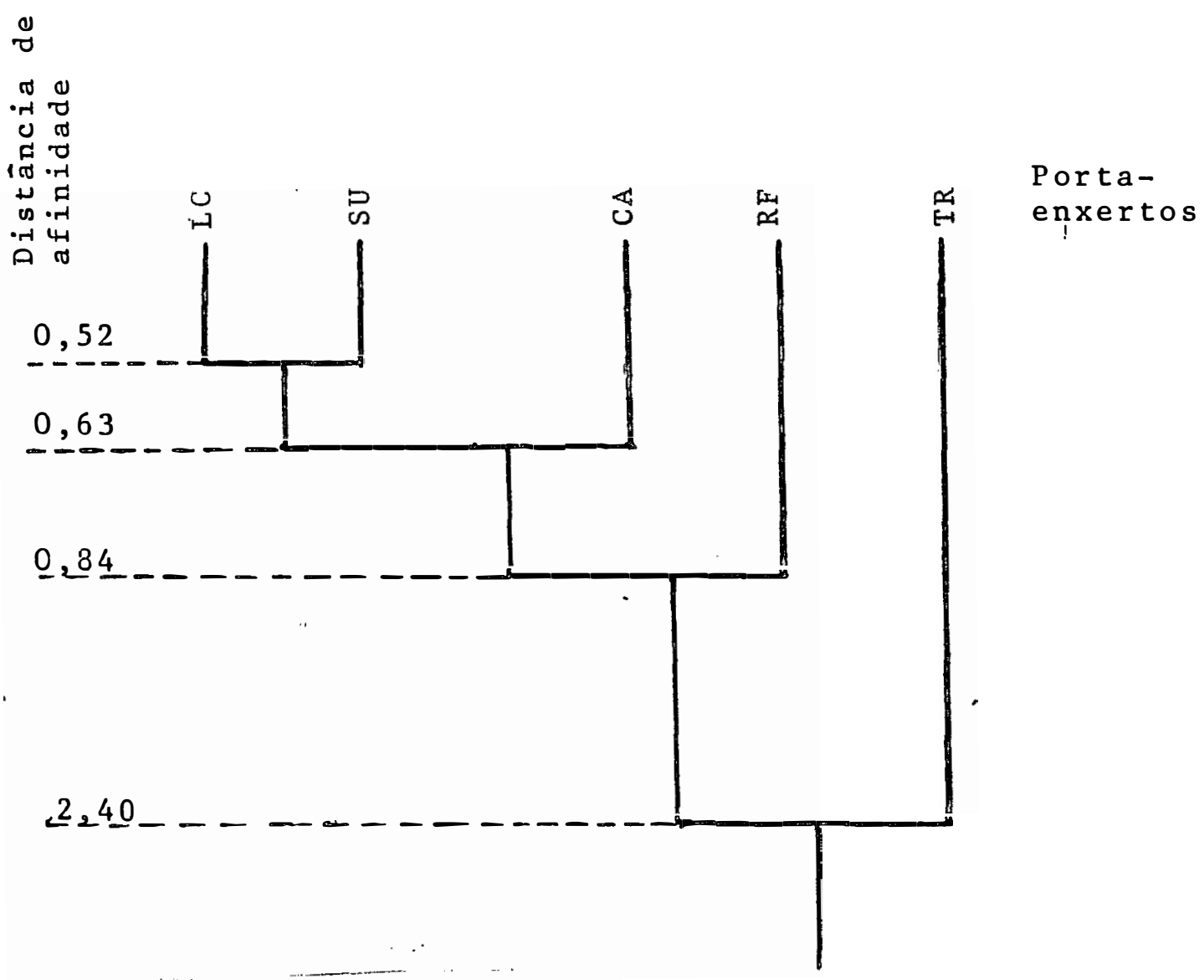

FIGURA 18. Fenograma representativo de porta-enxertos afins para a laranjeira 'Westin', determinados em funcão dos parâmetros: sintomas de Tristeza ("stem pitting" em ramos e indexação em limão Galego), vi gor e produção, pelo método da Análise de Agrupamento. 
5. DISCUSSÃO

5,1. Avaliação de sintomas em plantas indicadoras

os resultados obtidos nas indexações relatadas no presente trabalho, confirmaram a presenca do virus da Tristeza na copa da laranjeira 'Westin', independentemente do porta-enxerto utilizado o que concorda com as afirmacões de WALLACE (1978), no sentido de não existir influēncia do porta-enxerto na suscetibilidade da variedade enxerta da já que é condição própria do vegetal desde que os efeitos injuriosos, o "stem pitting" ocorram quando as mesmas cresçam como plantas enxertadas ou como seedlings. O caracter endemico do virus da Tristeza nos pomares comerciais e experimen tais no Brasil, segundo o assinalado por MOREIRA e SALIBE (1969), è igualmente confirmado.

Não houve diferenças significativas entre os valores das mëdias nas avaliações dos sintomas "stem pitting" 
ou caneluras e sintomas em folhas das plantas indicadoras de limoeiro Galego. Verifica-se que houve uma média de notas das avaliações dos parametros estudados respectivamente de $3,94 \cong 4$ e $4,05 \cong 4$, para sintomas de "stem pitting" e sinto mas em folhas das plantas teste; o que confirma a presença de uma raça severa do virus da Tristeza afetando as copas da laranjeira 'Westin'; resultados que se assemelham aos obtidos por SALIBE e MISCHAN (1976) e SALIBE (1977) e baseados na metodologia descrita por WALLACE (1968), e de acordo com a escala de notas utilizadas por MÜLLER (1972) e MONTEVERDE (1981), MENECHINO (1983) e outros na avaliação de sintomas do virus da Tristeza em plantas indicadoras.

A presença do virus da Tristeza na laranjeira 'Westin' foi primeiramente assinalada por SALIBE .e. MOREIRA (1972), ao caracterizar a variedade (clone velho) como sendo portadora de sintomas "leves" de "stem pitting" o que difere dos resultados do presente trabalho, realizado com clones nu celares.

No estudo das equações de regressão (Tabela 3) mostrou-se que a presença da raça do virus não foi afetada pelo vigor (parametros fisicos) nos diferentes porta-enxertos, através dos modelos de regressão estudados.

De igual maneira (vide pag. 53), foram analisados os coeficientes de correlaçoes dentro de cada porta-en xerto (Tabela 4), não existindo significāncia apra eles, o que permitiu indicar que qualquer possibilidade de variacóes 
no grau de severidade do virus da Tristeza ou as expressões na sintomatologia do virus devem ser atribuidas a diferenças entre porta-enxerto e não a diferenças dentro dos mesmos por ta-enxertos.

\subsection{Avaliação de "stem pitting" na laranjeira 'Westin'}

A anälise estatistica mostra variações altamente significativas da presença de "stem pitting" ou canelu ras em ramos da laranjeira 'Westin', dependendo do porta-enxerto utilizado. Confirmando a hipótese formulada por Bitters et alii (1953) citado por WALLACE (1978), quando assina laram que "parece ser que algumas variedades de porta-enxertos predispoe as copas de laranja doce ao "stem pitting", acrestando poder ocorrer o caso conträrio". A literatura con sultada e em trabalhos como os de CRANE (1945), MILBRAITH e ZELLER (1945), DUCHARME e KNORR (1954), GRANT et a $i i$ (1960 e 1961) e SALIBE (1965, 1973 e 1977), MüLLER et a $i i i$ (1968), McCLEAN (1974) e SALIBE e MISCHAN (1976), explicam resultados semelhantes como sendo produto da influéncia do porta-enxerto ou em qualquer dos casos como resposta da interação entre a variedade copa e o porta-enxerto e os graus de tolerāncia ao virus da Tristeza.

Verifica-se que os maiores valores de "stem pitting" foram obtidos para o tratamento 5 o geja o porta-enxerto trifoliata (Poncirus trifoliata Raf), e os menores 
.84.

valores para o tratamento 4 ou seja o limoeiro Cravo (Citrus limonia osbeck), não existindo diferença estatística à $5 \%$ de probabilidade entre os porta-enxertos laranjeira Caipira (Citrus sinensis osbeck) e entre os porta-enxertos tangeri neira Sunki (Citrus sunki Hort ex Tan) e Limoeiro Cravo (C. limonia osbeck) e entre eles e limoeiro Rugoso da Flórida (Citrus jambhiri Lush).

SALIBE e MISCHAN (1976) e SALIBE (1977), estu dando o efeito do porta-enxerto na expressão de "stem pitting" de Tristeza em laranjas doce, e sobre diferentes hospe deiros e sua importancia economica, encontraram que os porta -enxertos influenciaram a expressão de "stem pitting" nos ra mos das variedades de laranjeiras doce, sendo que os resulta dos obtidos por eles concordaram em parte com os resultados do presente trabalho, ao afirmar ser o porta-enxerto tri foliata o mais afetado, embora defira do porta-enxerto menos afetado, o que, segundo seus resultados, tem sido a tangeriṇeira Sunky, com algumas variações, e que no caso foi o 1 imoeiro Cravo.

Para nenhum dos tratamentos ou porta-enxertos os valores das notas, na escala de 1 a 5 , para expressão de "stem pitting" nos ramos da laranjeira 'Westin' foram supe-, riores a 1,47 , quer dizer, considerandos como 1igeiramente afe tado a moderadamente afétado por "stem pitting", o que concorda com os resultados obtidos por SALIBE e MOREIRA (1972) : e SALIBE (1977) e diferindo com os obtidos por MÜLLER et a 
(1968), SALIBE (1973) e SALIBE e.MISCHAN (1976), os quais ob tiveram valores de avaliação de "stem pitting" de 3 a 3,8 , é considerado como severamente afetado por "stem pitting" ou "severely pitted".

Convém destacar o fato que as anteriores avaliações foram realizadas sobre diferentes porta-enxertos, co mo limoeiro Cravo (Citrus limonia 0sbeck), tangerineiras e Hibridos de trifoliata, porém os mesmos não apresentaram, ex ceto os trabalhos de SALIBE e MISCHAN (1977), os resultados ou classificação previa da raça do virus presente nas variedades copa, a fim de estabelecer o grau de atenuação ou influéncia comparada da intensidade de "stem pitting" nos ra mos da:variedade, as quais poderiam medir a influéncia do porta-enxerto na expressão de sintomas da doença. Estas afirmações baseiam-se nos resultados obtidos no presente trabalho para indexação do virus da Tristeza. Embora tenha sido detectado uma raça severa de virus de Tristeza (Nota 4, em "stem pitting" e sintomas de folhas em plantas teste de limoeiro Galego),os valores das notas da avaliação de "stem pitting" em ramos da laranjeira 'Westin', ficou compre endida entre as notas 1 a 2 (média geral =0,99), o que permitiu medir o efeito do porta-enxerto na sintomatologia do virus.

Existiu, no entanto, caracteres produto da interação copa-cavalo, como é o caso do desempenho total no de senvolvimento do vigor da copa e cavalo, que permitiram a 
existência de maior ou menor quantidade de "stem pitting" e logicamente, notas maiores ou menores na avaliação de sintomas. No caso deste trabalho foi demonstrado este efeito ao existir significancia de correlação entre "stem pitting" e altura de planta e "stem pitting" e produção (Tabela 3). Os resultados, mostraram que existe uma maior ou menor presença do "stem pitting" na copa de acordo com a àtura o que induz que para plantas com maiores alturas. menores serão as expressões do virus na copa das mesmas. Quer dizer, menores sintomas de "stem pitting" em ramos e portanto menores quantidades do virus afetando as copas da láranjeira 'Westin'.

Outro fator importante estudado foi a influẹn cia negativa do "stem pitting" em ramos na produção em quilo gramas de frutos por parcela para as colheitas do período 1969-1974, o qual é detectado através de correlação entre os parâmetros "stem pitting" em ramos e produção. A discussão do fato será realizada no parāmetro vigor.

\subsection{Vigor das píántas}

0. vigor da laranjeira 'Westin' foi afetado de forma muito marcante pelos porta-enxertos, como se pode veri ficar pela significância dos valores de F, na Tabela 7 . Pode-se observar que exceto para o parämetro indice de confor- 
.87.

mação, com significância ao niveı de $5 \%$ de probabilidade,nos demais parâmetros físicos o efeito dos porta-enxertos foram significativos ao nivel de $1 \%$ de probabilidade.

Na mesma Tabela 7 (pägina 61), pode-se observar para o parâmetro diāmetro da copa ( $\emptyset)$ um $F$ significativo para blocos, o qual pode ser atribuido as variações possiveis de solo, jä que geralmente sö se apresentou num bloco na mesma disposição no campo, e as presenças da broca dos ci tros, Cratosomus flavofasciatum G., afetando parcialmente 5 plantas, nas diferentes parcelas. No entanto, os valores dos coeficientes de variação são baixos $(4,68 \%$ a $8,47 \%)$, segundo Pimentel gomes (1981).

Ao analisar de maneira conjunta os valores das médias dos diferentes parametros fisicos do vigor, pode -se observar que os porta-enxertos de laranjeira Caipira, Tan gerineira Sunki e limoeiro Cravo induziram a formação, de um modo geral, de plantas mais vigorosas no presente ensaio. 0 limoeiro Rugoso da Flörida induziu plantas de bom vigor, no entanto, o Trifoliata resultou ser o portarenxerto com menor vigor para os diferentes parametros analisados. Resultados que concordaram com os reportados pela literatura consultada, tais como TEOFILO SOBRINHO (1972), SALIBE (1974), SALIBE e MISCHAN (1976) e SALIBE (1977) entre outros. 
te de Tuckey para circunferéncia do tronco, dentro dos porta -enxertos (Tabela 8), mostrou que o porta-enxerto trifoliata foi o que obteve valores significativamente menores, não existindo diferenças signficativas ao nível de $5 \%$ de probabilidade entre os porta-enxertos laranjeira Caipira e tangerineira Sunki as quais resultaram com os maiores valores de circunferência do tronco, e com valores intermediärios, sem diferir, os porta-enxertos Limoeiro Rugoso e limoeiro Cravo. Estes resultados concordam, exceto para o Limoeiro Cravo,com os obtidos por SALIBE (1974) e SALIBE e MOREIRA (1973), ao trabalhar com vários porta-enxertos para laranjeiras doce.

No caso do diāmetro da copa da laranjeira

'Westin' observa-se (Tabela 8) a existência de diferenças en tre médias para os diferentes porta-enxertos pelo teste de Tuckey ao 5\% de probabilidade. Iguais diferenças significativas são mostradas para os parametros do vigor: altura de planta, indice de conformação e àrea produtiva.

Os resultados obtidos mostram uma sequência quase inalterävel para os diferentes parametros do vigor exceto para o diâmetro das plantas, constituida por laranjeira Caipira,tangerineira, Sunki, Limoeiro Cravo, Limoeiro Rugoso da Flörida e com menor grau de vigor e desenvolvimento encon trasse a Trifoliata (Poncirus trifoliata Lush). No caso do diâmetro das copas ocorre uma alteração na sequência :entre os porta-enxertos Limoeiro Rugoso da Flórida, tangerineira Sunki, ocupando o terceiro lugar e o limoeiro Cravo no quar- 
to lugar na sequência do parâmetro mencionado; embora não exista diferença significativas ao nivel de $5 \%$ de probabilidade pelo teste de Tuckey entre os porta-enxertos citados. .

No caso do parâmetro altura da planta não existiu variação na sequência determinada na análise em con junto, ainda que, junto ao parâmetro diâmetro da planta permitiramestudar o indice de conformaça da planta e que determinou a forma predominante para as diferentes copas. Assim, os diferentes porta-enxertos fizeram com que existisse uma tendencia a formar copas globosas, tais como a tangerineira Sunki e laranjeira Caipira, e copas mais largas tais como: Trifoliata e limoeiro Rugoso.

A laranjeira Caipira resultou ser o porta-enxerto com maior ärea produtiva, sem diferir estatisticamente da tangerineira Sunki e limoeiro Cravo e entre este e o limoeiro Rugoso da Flórida. A menor área produtiva foi determinada para o portarenxerto Trifoliata. Estes resultados man tiveram a ordem estabelecida inicialmente pará vigor no presente trabalho.

A Tabela 9 mostra que as correlações entre circunferencia do tronco e os parâmetros diàmetro de copa e área produtiva foram significativas ao nivel de $1 \%$ de probabilidade, o mesmo resultou para a correlaça entre altura de planta e área produtiva.

Para a correlação entre os parâmetros circun- 
cunferência do tronco e altura de planta houve significância ao nivel de $5 \%$ de probabilidade. Não existiu significância para as correlações entre altura da planta indice de conformação, e àrea produtiva, o que pode ser explicado pelas diferentes formas de copas da laranjeiras 'Westin', influenciadas pelos diferentes porta-enxertos. Resultados que coin cidiram com os obtidos por TEOFILO SOBRINHO (1972), SALIBE e MOREIRA (1973) e SALIBE (1974).

\subsection{Produção}

As produções médias em quilogramas/parcela pa ra o periodo 1969-74 e número de caixas/parcela (1980-82) da laranjeira 'Westin' foram afetados pelos porta-enxertos utilizados e a presença de "stem pitting" na copa da planta; co mo se constata respectivamente, pela significāncia dos valores de $F$ ao nivel de $1 \%$ (Tabela 10) e pela correlação a 1 tamente significativa ao nivel de $1 \%$ entre a presenca de "stem pitting" e produção (kg/parcela) do periodo 1969-74 (Tabela 3).

Os porta-enxertos de 1 imoeiro Cravo e tangerineira Sunki induziram producões significativamente maiores que os demais porta-enxertos. O Trifoliata induziu as menọres produções. Ocupando posição intermediäria os portaenxertos laranjeira Caipira e o limoeiro Rugoso da Flörida, sem diferir entre si. Confirmou-se a superioridade do 1 i- 
moeiro Cravo.

As comparações entre as produções dos periodos 1969-74 e 1980-82 permitiu as avaliações, no tempo, das caracteristicas de desenvolvimento e vigor da planta o qual foi afetado pela influéncia do porta-enxerto e a presença de "stem pitting" na copa.

As caracteristicas da laranjeira Caipira de retardar a produção (MARLOTH, 1950; SALIBE, 1969; PASSOS et a $i$ i, 1970 e SALIBE, 1974), fez com que ocupasse o ültimo lugar na produção 1969-74, sem diferir do limoeiro Rugoso da Flórida e Trifoliata. Nas produções do periodo de,1980-82, colocou-se no primeiro lugar sem diferir da tangerineira Sun ki). Assim, nas plantas em que a incidência dos sintomas de "stem pitting" foi menor, maior foi o vigor, crescimento vegetativo e àrea produtiva.

0 limoeiro Cravo confirma a sua extraordinā ria precocidade e produção elevada nos primeiṛos anos de co 1heita (MOREIRA et a $i i i, 1962$ e 1965; SALIBE e MOREIRA,1968; SALIBE et $a$ Zi $i, 1970$; TEOFILO SOBRINHO, 1972 e SALIBE, 1974), Para o periodo 1980-82, a sua produção fez com que ocupasse lugar intermediärio entre os diferentes porta-enxertos, observando-se a mesma tendēncia na anālise de resultados da ärea produtiva e com intensidade de "stem pitting".

o limoeiro Rugoso da Flörida manteve um comportamento estável em relação as produções, não alterando a 
sequência estabelecida na ordem decrescente. Ocupou os últi mos lugares não diferindo com o porta-enxerto trifoliata. Re sultados que coincidem com SALIBE (1974) e discordam das observações de PASSOS et alii (1970) e TEOFILO SOBRINHO (1972).

o porta-enxerto de trifoliata. induziu, compara tivamente, baixas produções as plantas, nas colheitas 1969-74 e 1980-82. Conferiu a copa o menor volume, ficando no último lugar na sequēncia de produções, embora não tenha diferido da laranjeira caipira e limoeiro rugoso nas produções no periodo 1969-74. O trifoliata foi o porta-enxerto com o maior valor de notas das intensidades de "stem pitting" o que pode ter influido no lento crescimento e,em geral, no pouco vigor apresentado. Como consequéncia de seu pouco vigor, a sua ärea produtiva foi menor, com o que possui as maiores possibilidades de incrementar a multiplicaça do virus é,por tanto, maiores possibilidades de presença de particulas do virus.

os fatos anteriores são confirmádos nos resul tados dos estudos das significāncias nas diferentes correlações possiveis entre o parāmetro da produção (caixas de frutos/parcela) e os diferentes parametros estudados: Assim, existiu uma tendência, em geral, de obter maiores produções por caixa de frutos nas combinaçöes de laranjeira 'Westin' sobre os diferentes porta-enxertos, que induairam os maiores vigores nas copas. Plantas bem mais desenvolvidas induziram maior nümero de caixas de frutos. Os parámetros 
indice de conformação e produção (kg por parcela) não se obteve correlação significativa. 0 mesmo aconteceu com a produção (kg/parcela) do periodo 1969-74 quando se estudou sua correlação com o parâmetro nümero de caixas de frutos/parce1a. Embora, a sua tendência e valor negativo da correlação indicaram as diferentes caracteristicas de desenvolvimento e produção ao qual induziram os diferentes porta-enxertos. Is to baseado na precocidade ou lentitude na produçã assinalada no presente estudo.

Embora nảo houve significância para as correlações entre o fator produção analisado e os sintomas de "stem pitting" de Tristeza, seus valores respectivos foram altos o que confirma uma possivel influéncia de sua presença na produção para as colheitas dos anos 1980-82, mostrada para o periodo da safra 1969-74.

5.5. Seleção de grupos afins de porta-enxertos

O método de anâlise de componentes principais, separou os portarenxertos, laranjeira Caipira, tangerineira Sunki, limoeiro Rugoso da Flörida, limoeiro Cravo e Trifoliata, em quatro grupos em função dos sintomas de Tristeza (2Stem pitting" em ramos e planta teste), vigor e produção das copas da laranjeira 'Westin' (Figuras 17 e 18). As- 
sim, para o eixo "x" a explicação na formação dos grupos foi de 59,3\%; o eixo "y" teve uma explicação de 21,59\% e o eixo "z" teve uma explicação de $14,22 \%$ na formação dos grupos. Pa ra esses eixos ortogonais os parämetros analisados que resul taram mais determinantes na formaça dos grupos foram respec tivamente, eixo "x": circunferēncia do tronco e altura da planta; eixo "y": produção e presença de "stem pitting" e e xo "z": indice de conformação e presença de "stem pitting".

Como resultado final da. Anälise.de Componentes Principais e da Anälise de Agrupamentos foram determinados os grupos similares:

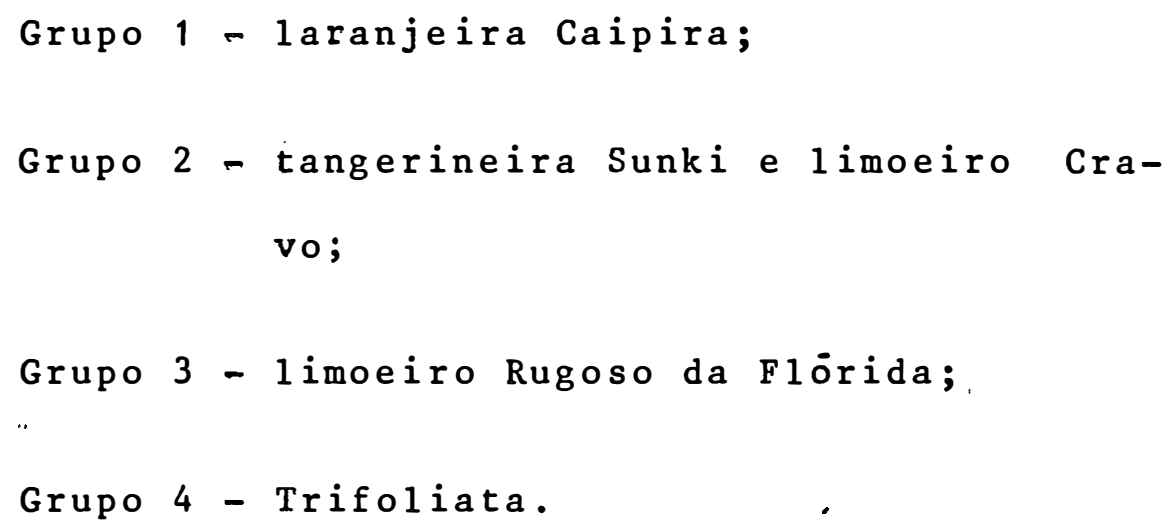




\section{CONCLUSÖES}

As interpretações dos resultados das pesquisas relatadas permitem as seguintes conclusões :

- Constatoumse a presença de uma raça severa do virus da Tristeza, nas copas da variedade 'Westin' sobre os diferentes porta-enxertos atravès da indexaça em plantas de 1 imoeiro Galego.

- A quantidade de "stem pitting." de Tristeza nos ramos da copa da laranjeira 'Westin' foi afetado pelos porta-enxertos utilizados.

- Classificou-se a laranjeira 'Westin' como Zigeiramente afetado pela presença de "stem pitting" de Tris teza (Nota $1-2)$.

- As copas das laranjeiras 'Westin' sobre o porta-enxerto Trifoliata mostraram as maiores quantidades de 
"stem pitting". As menores quantidades nas copas sobre o $1 \underline{i}$ moeiro Cravo e com quantidades intermediárias copas sobre os porta-enxertos tangerineira Sunki, lantajeira Caipira e 1imoeiro Rugoso da Flörida.

- A produção de laranjeira 'Westin' foi influenciada pelos diferentes porta-enxertos. Houve alta correlação entre maior presença de "stem pitting"em ramos da la ranjeira 'Westin' e menor produção.

- A laranjeira Caipira, o 1 imoeiro Cravo e a tangerineira Sunki, induziram as maiores produções nas copas da 1 aranjeira 'Westin'. Os porta-enxertos 1 imoeiro Rugoso da Flörida e Trifoliata, apresentaram valores intermediärios ou baixos de produções.

- Constatou-se nas colheitas dos primeiros 6 anos a precocidade na produção do Limoeiro Cravo como portar -enxerto, enquanto que o porta-enxerto de laranjeira Caipira retardou a produção. O comportamento na produção dos demais porta-enxertos permaneceu invariāvel na sua posição atravès dos anos de estudo.

- Os, porta-enxertos que induziram os maiores vigores proporcionaram as maiores produções nas safras dos anos 1980 e 1982 .

- Ao se agruparem os porta-enxertos estudados atravês da Anälise dos Componentes Principais, e da Anälise 
de Agrupamento, verificou-se a existēncia de quatro grupos diferentes de porta-enxertos:

Grupo 1: laranjeira Caipira;

Grupo 2: 1imoeiro Cravo, tangerineira Sunki;

Grupo 3: limoeiro Rugoso da Fiórida;

Grupo 4: Trifoliata.

- Determinou-se a grande influência dos parāmetros: circunferéncia do tronco, produção e presença de "stem pitting", nos estudos de seleção de grupos similares de porta-enxertos para a laranjeira 'Westin'. 
.98 .

\section{LITERATURA CITADA}

ANDRADE, V.M.M., D.N. DOS SANTOS, L.C. DONADIO e S,T. USHIROBIRA, 1978. Determinação de algumas características das laranjeiras doces Westin e Maracanã (Citrus sinensis L. osbeck). Cientifica, Jaboticaba1, 6(1): 93-100.

采 ARAUJO, C.M. e H.O. VASCONCEllos, 1966. An unreported symptom of tristeza. Conference of the International Organization of Citrus Virologists 4, Gainesville, p. 38-41 .

BAR-JOSEPH, M., 1979. The use of enzyme-1inked immuno sorbent assay foṛ, detection of citrus tristeza virus. Phytopathology 69(2): 190-194.

BAR-JOSEPH, M. e G. LOEBENSTEIN, 1970. Rapid diagnosis of the Citrus tristeza disease by electron microscopy of partially purified preparations. Phytopathology 60(10): 1510-1512. 
BAR-JOSEPH, M. e G. LOEBENSTEIN, 1974. Effect of temperature on concentracion of threadike particles stem pitting, and infectivity of budwood from tristeza-infected Palestine Sweet Lime. Proceedings $6^{\text {th }}$ Conference International Organization Citrus Virologist, Riverside p. 86-88.

BAR-JOSEPH, M., G. LOEBENSTEIN e J. COHEN, 1970. Partial purification of viruslike particles associated with the citrus tristeza disease. Phytophatology 60(1): 75-78.

BAR-JOSEPH, M., G. LOEBENSTEIN e Y. OREN, 1974. Use of electron microscopy in eradication of tristeza sources recently found in Israel. Proceeding $6^{\text {th }}$ Conference International Organization Virologists, p. 83-85.

BAR-JOSEPH, M., J.H. SACKS e S.M. GARNSEY, 1978. Detection and estimation of citrus tristeza virus infection rates base on ELISA assays of packing house fruit samples. Phytoparasitica $\underline{6}(3): 145-149$.

BAR-JOSEPH, M., Y. SHARAFI e M. MOSCOVITZ, 1979. Re-using the non-sandwiched antibody-enzime conjugates of two plant viruses tested by enzyme-linked immunosorbent assay (ELISA). Plant Disease Reporter 63(3): 204-206.

BENNET, C.W. e A.S. COSTA, 1948. A preliminary report of work at Campinas, Brasil on tristeza disease of citrus. Proc. Fla. State. Hort. Soc., 60: 11-16. 
BENNET, C.W. e A.S. COSTA, 1949. Tristeza disease of citrus. Journal Agricultural Research 78(8): 207-237.

BItANCOURT, A.A., 1940. A doença dos citrus no Vale do Paraiba. O Biolögico, SP, 6: 268-269.

BITANCOURT, A.A., 1944. Um teste para a identificação preco ce da Tristeza dos Citros. O Biológico, São Paulo, 10: $169-175$

BItANCOURT, A.A., 1951. Studies on the "tristeza" disease of citrus. II. Susceptibility of the different stock-sción combination of sweet orange and sour orange. $O B i \underline{O}$ Zögico - Arq. do Instituto Biológico 20 (art. 4):39-52.

BITTERS, W.P., 1953. Stem pitting on citrus trees. CaZifornia Agriculture, USA, 프: 9-14.

BITTERS, W.P。 e E.R. PARKER, 1952. Quick decline of citrus as influenced by top-root relationships. California Agricultural Experimental Station Bulletim; 733 p.

BITTERS, W.P., N.W. DUKESHIRE e J.A. BRUSCA, 1953 ., Stem pitting and quick decline symptoms as related to root-: stock combination. Citrus Leaves 33(2): 8-9,38.

BOVE, J.M., 1967. Maladies a virus des citrus dans les pays du basin mëditerranéen. Fruits 22(3): 125-140.

BRIEGER, F.G。e S。MOREIRA, 1945. Experièncias de cavalos. para citros. II. Bragantia, São Paulo, 5:597-658. 
.101.

CAMARGO, A.P., H.S. PINTO, M.J. PEDRO JUNIOR, R.R. ALFONSI e A.A. ORTOLANI, 1974. Clima do Estado de São Paulo. In Secretaria da Agricultura. Zoneamento Agricola do Estado de São Paulo, São Paulo, vol. 1 .

CAPOOR, S.P., 1965. Presence of seedling yellows complex in the citrus of South India. Proceedings $3 d$. Conference of International Organization of Citrus Virologists, Gainesville, F1a.p. 30-35.

CAPOOR, S.P., 1975. Role of the tristeza virus in citrus die-back complex. Indian Journal of Horticulture, $32(1 / 2)$ $: 1-6$.

CARRERA, C., 1933. Informe preliminar sobre una enfermedad nueva comprobada en los citros de Bella Vista (Corrientes), Argentina. Boletin Mensual Ministërio de Agricultu ra, Argentina 34: $275-280$.

CARVALHO, W.A., C.R. ESPINDOLA e A.A. PACCOLA, 1983. Levantamento de solos da Fazenda Lajeado - Estação Experimental "Presidente Medici". Boletim Cientifico Faculdade Ciências Agronômicas, Botucatu 1: 1-95.

CEREDA, E., 1981. Competição e caracterização de cultivares de laranja doce Citrus sinensis (L.) osbeck de baixa acidez. Botucatu. Fac. Ciên. Agron. Universidade Estadual Paulista. 91 p. (Tese de Livre Docência). 
COHEN, M., 1967. Tristeza strain comparisons in Florida. Phytopathology 57: 807 .

COMISSÃO DE SOLOS, 1960. Levantamento e reconhecimento dos solos do Estado de São Paulo. Bol. Ser. Nac. Pesq. Agron. Rio de Janeiro (12): 1-634.

COSTA, A.S., 1956. Present status of the tristeza disease of Citrus in South America. F.A.O. Plant Protection Bulzetin $4: 97-105$.

COSTA, A.S., T.J. GRANT e S. MOREIRA, 1949. Investigações sobre a tristeza dos citrus. Bragantia, SP, 9: 59-80.

COSTA, A.S., T.J. GRANT e S. MOREIRA, 1954. Behavior :of various citrus rootstock-scion combinations following inoculation with mild and severe strains of tristeza virus. Proc. Fla. Hort. Soc., Florida, 67: 26-30.

CRANE, M.B., 1945. Origin of viruses. Nature, London, 155: $115-116$

CUÑAT, P., E. HERNANDEZ, E. PRIMO e R. VILLA, 1973. Virosis de los citricos III. Técnicas serolögicas para el diagnóstico de la tristeza de los citricos. Revista Agroquimiea Tecnologia Alimentos, España, 13: 274-278. 
Ctil, P.R., 1972. Relacōes entre evaporạāo medida pelo tan

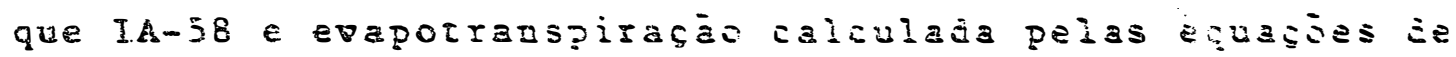

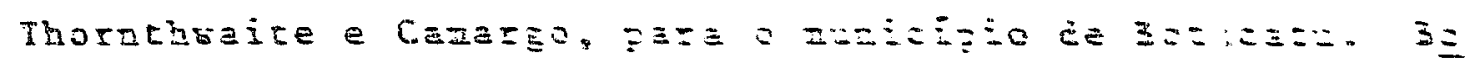

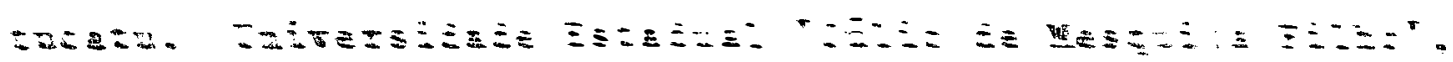

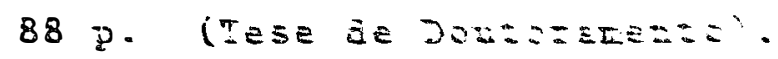

DUCHARME, E.P., 1951. Naturaleza y control de la tristeza de los citrus. Revista de Investigaciones Agricolas, Bue nos Aires. $\underline{3}: 318-351$.

DUCHARME e KNORR, 1954. Vascular pits and pegs associated with disease in citrus. Plant Disease Reporter 38: 127-42 .

FAWCETT, H.S., 1946. A progress report on quick decline studies: Introduction (Part I); Starch relationship (Part III).California Citrograph 31: 198 .

FAWCETT, H.S. e J.M. WALLACE, 1946. Evidence of the virus nature of citrus quick decline. California Citrograph 32: $88-89$.

FOGUET, J.L., 1978. Westin. Variedad de naranja temprana para el Noroeste: Argentino. Est. Exp. Agric. de Tucumän Circular n\& 206. 5 p.

GARNSEY, S.M., 1973. The effects of virus and viruslike diseases on citrus production in Florida. Proceedings First International Citrus Short Counse, Gainesville, USA, p . 77-86. 
X' Garnsey, S.M., D. GONSAlves e D.E. PURCIFUll, 1977.

Mechanical transmission of citrus tristeza virus. Phytopathology, 67: 965-968.

GARNSEY, S.M., D. GONSALVES e D.E. PURCIFULL, 1979. Rapid diagnosis of citrus tristeza virus infections by sodium dodecyl sulfate-immunodiffusion procedures. PhytopathoZogy. $69(1): 88-95$.

GIACOMETTI, D.C., 1961. Stem-pitting threat to Brazil

Citrus. California Citrograph. 46: 243-244.

GIACOMETTI, D.C. e A.S. COSTA, 1958. Nurserybehaviour of infected West Indian lime scions on tristeza tolerant and intolerant roostocks. Plant Disease Reporter, USA, $42(8)$ : $928-932$.

GONSALVES, D., S.M. GARNSEY e D.E. PURCIFULL, 1977 . Research on citrus tristeza virus generates some rapid identification procedures. Proceeding Florida State. Horticultural Society. 90: 75-79.

GRANT, T.J., 1959. Tristeza virus disease. Citrus virus disease. University of California Div. of Agri., Sci. p. 45-55.

GRANT, T., 1959. Tristeza virus strains in relation to different citrus species used as test plants. Phytopathology $49(12): 823-827$. 
GRANT, T.J. e A.S. COSTA, 1951. A mild strain of the triste za virus of citrus. Phytopathology 41(2): 114-122.

GRANT, T.J., A.S. COSTA e S. MOREIRA, 1951. Variations in stem pitting on tristeza-inoculated plants of different citrus groups. The Citrus Industry, USA, 32(12): 5-7, 15,18

GRANT, J.T. e R.P. HIGGINS, 1957. Occurence of mixtures of tristeza virus strains in citrus. Phytopathology 47(5): $272-276$.

GRANT, T.J., S. MOREIRA e A.A.SALIBE, 1960. Report on general aspect of tristeza and stem pitting in citrus varieties in São Paulo, Brasil. Proceedings of the Florida State Horticultural Society 73: 13-16.

GRANT, T.J., S. MOREIRA e A.A. SALIBE, 1961. Citrus variety reaction to tristeza virus in Brasil when used in various rootstocks and scion combinations. Plant Disease Reporter, 45(6): 461-421.

GRANT, T.J., S. MOREIRA e A.A.SALIBE, 1961. Tristeza and stem pitting in Brazil. In: PRICE, W.C. (ed.). Proceedings 2nd. 'Conference of the International Organization of Citrus Virologists, Gainesville, Flo. p. $116-120$. 
HUGHES, W.A. e C.A. LISTER, 1953. Lime dieback in the Gold Coast, a virus disease of the lime, Citrus aurantifolia (Christmann) Swingle. Journal Horticultural Science, 28: $131-140$.

KITAJIMA, E.W., M.S. DARCY, A.R 。 OLIVEIRA, G.W. MÜLler e A. S. Costa, 1964. Thread-like particles associated with tristeza disease of citrus. Nature, London 201(4923): $1011-1012$.

KNORR, L.C., 1956. Suscepts, indicators and filters of tristeza virus, and some differences between tristeza in Argentina and in Florida. Phytopathology 46: 557-560. KOLLER, O.C., 1975. Influēncia do virus da "tristeza dos cí tros" sobre a absorção e translocação do zinco. Piracica ba, ESALQ-USP, 142 p. (Tese de Doutorado).

Ko0, R.C.J., 1967. Effects of the soil amendments on soil moisture and growth of young orange trees. Proceedings Fla. St. hort. Soc. 80: 26-32.

MARLOTH, R.H., 1950. Sweet orange as rootstock for citrus. In: Union of South Africa Depart. Agric. Bull. (302): 1, 17 .

MC ALPIN, D.M., P.S. PARSAI, R. ROBERTS e R.H. HOPE, 1948. "Bud-union decline" desease in citrus trees. Vietoria Department Agricultural Journal 46: 25-31. 
McClEAN, A.P.D., 1950. Possible identity of three citrus diseases. Nature, London 165:767-768.

MCCLEAN, A.P.D., 1956. Tristeza and stem pitting diseases of citrus in South Africa. F.A.O. Plant Protection Bulz. 4. $88-94$.

McCLEAN, A.P.D., 1960. Seedlings yellows in South African citrus trees. South African Journal Agricultural Seience 3: $259-279$.

McCLEAN, A.P.D., 1963. The tristeza virus complex. Its variability in field grown citrus in South Africa. South African Journal Agricultural Science 6: 303-332.

MCCLEAN, A.P.D., 1974. The tristeza virus complex. Proceedings Conference 6th of the International Organization of Citrus Virologists, Riverside, 59-66 p.

MENECHINO, J.Jr., 1983. Efeito do virus da tristeza no vigor, produtividade das plantas e qualidade da fruta de três variedades de laranja de maturação tardia, Cithus s $\underline{i}$ nensis (L.) osbeck. UNESP/Botucatu, SP. 86 p. (Tese de Mestrado).

MENEGHINI, M., 1946. Sobre a natureza e transmissibilidade da doença "tristeza" dos citros. O Biologico, São Paulo, 12: $285-287$. 
MILBRAITH, J.A. e S.M. ZELLER, 1945. Latent viruses in stone fruits. Science 101: 114-115.

MONTENEGRO, H.W.S., 1960. Contribuição ao estudo do sistema radicular das plantas cirricas. Piracicaba, ESALQ-USP, 143 p. (Tese de Càtedra).

MONTEVERDE, E., J.RUIZ e M. FIGUEROA, 1981. Estudio preliminar de las razas de tristeza presentes en Venezuela. Re sumenes de Ponencias III Seminario Nacional de Fruticultu ra. Valencia, Carabobo, Venezuela, $14 \mathrm{p}$.

MOREIRA, S。, 1941. Experiencias de cavalos para citros I. Bragantia, São Paulo, 1: 525-565.

MOREIRA, S., 1942. Observações sobre a "!ticisteza" dos citrus ou podridão das radicelas. O Biológico, São Paulo, 8: $269-276$.

MOREIRA, S., 1946. Cavalos para citros em são Paulo. Revis ta Agricultura, Piracicaba, 21: 206-226.,

MOREIRA, S., 1950. A seleção em Citricultura: Uma nova variedade de laranjeira doce (C. sinensis (L) osbeck). Ciên cia e Cultura, Sä̀o Paulo, $\underline{3}(1):$ 27-28.

MOREIRA, S., 1954. Porta-enxertos para citros: resultados experimentais. Anais II Congresso Panamericano Agronomia Piracicaba, p. 230 . 
MOREIRA, S., 1956. Citrus disease and rootstock problems in Brazil. Livre du IVeme Congress Internationale de l'Agri culture Mediterraneenne, Te1-Aviv. p. 252-259.

MOREIRA, S., 1959. Tristeza..na laranja Pera. Boletim. Cam po Blemco S.A. $123: 3-4$.

MOREIRA, S., 1960. Um novo problema para nossa citricultura. Revista de Agricultura, Campinas, 35(2): 77-81.

MOREIRA, S., 1961. Laranja Westin. Chacaras e Quintais, São Paulo, 103(4): 415-416.

MOREIRA, S., 1967. Iles Maurice et de la Reünion.! Enquéte sur les maladies des agrumes. BulZ. Phyto F.A.0., 15: 59-60.

MOREIRA, S. e C. ROESSING, 1965. Behavior of 77 tristeza tolerant rootstock with old and nucellar clones of Barão orange scions. Proceedings 3rd Conf. Inter. Organization Citrus Virologists. Gainesville, p. 299-301.

MOREIRA, S. e A.A. SALIBE, 1969. The contribution of research for the progressive changes in citrus rootstocks for South America.. Proceedings First International Citrus Symposium 1: 351-357.

MOREIRA, S., A.S. COSTA e T.J. GRANT, 1954. Metodos para identificação e controle da tristeza dos citros. Bragantia, SP, 13(19): 223-236. 
MOREIRA, S., V.G. OLIVEIRA e E. ABRAMIDES, 1960. Experimen.tos de cavalos para citros III. Bragantia, São Paulo, 19 : 961-995.

MOREIRA, S., C. ROESSING e E. ABRAMIDES, 1962. Experimentos de cavalos para citros IV. Bragantia, São Paulo, 12: 63-76 .

MOREIRA, S., A.A. SALIBE, V.G. OLIVEIRA, E. ABRAMIDES, 1965 . Experimentos de "Cavalos" para Citros v. Ciência e CuZtu ra, São Paulo, 17: 190-191.

MÜLLER, G.W., 1972. Estudos sobre a interação entre isolados do virus da tristeza dos citros e controle da moléstia em limão Galego por premunização. ESÁLQ-USP, Piraci caba, 80 p. (Tese de Doutorado).

MÜLlER, G.W., 1976. A tristeza dos citros. Summa Phytopathologica, Piracicaba, 2(4): 245-263.

MÜLler, G.W., 1980. Molestia de virus e micoplasma de citros. In: RODRIGUEZ, 0. e F. VIEGAS, Coord. Citricultura Brasileira. Campinas, SP. 2: 565-607.

MÜLLER, G.W. e A.S.CosTA, 1967. Estudo sobre interferência de estirpes de virus da tristeza. Rev. da Soc. Brasizeira de Fitopatologia, Piracicaba, SP, ano I, p. 66-69. 
MÜLLER, G.W., 0. RODRIGUEZ e A.S . COSTA, 1968. A tristeza virus complex severe to sweet orange varieties. Proceedings 4th International Organization Citrus Virologists, . Gainesville. p. 64-71.

MÜLLER, G.W., A.S. COSTA, A.R. OLIVEIRA e I.J.B. CAMARGo, 1969. Caneluras em laranjeiras doce inoculadas com o mal de Araraquara. Rev. da Soc. Brasizeira de Fitopatologia, Campinas, SP, Ano III, p. 66-68.

NARIANI, T.K. e S.P. RAUCHAIDHURT, 1971. Kayzi 1 ime - Common indicator plant for tristeza and truning viruses. Califor nia Citrograph, $\underline{56}(3) ; 85$.

7) OCHAE, J.J., 1949. Tristeza disease in Java. Proceedings of the Florida State. Horticultural Society 61: 33-35.

OLIVEIRA, A.R., 1964. Serologia com o virus da tristeza dos. citros. Revista Agronomica de Porto Alegre 16: 30-38.

OLIVEIRA, A.R., 1975. Considerações sobre antisoros obtidos pela técnica de. injeção de antígeno no linfonảdulo. Summa Phytopathologica 1: 61-64.

OLSON, E.0., 1956...Mild and sereve strains of tristeza virus in Texas citrus. Phytopathology 46: 336-341.

PASSOS, 0.S. e A.P. CUNHA, 1970. Porta-enxertos para Citros. II Encontro Nacional de Citricultura. Cruz das Almas, Bahia, 22 p 。 
PASSOS, O.S., A.P. CUNHA e E.M. RODRIGUEZ, 1970. Observações sobre o comportamento de porta-enxerto no Estado da Bahia. Resumos $22 a$ Reunião Anual da Sociedade Brasileira para o Progresso da Ciência, Salvador, 200 p.

PEYNADO, A., 1958. Devices for observing root growth and calipering tree trunks. Journal of Rio Grande Válley Hor ticultural Society, Weslaco, 12: 61-66.

PIMENTEL GOMES, F., 1981. Curso de Estatistica Experimental. 9a. Ed. Piracicaba, ESALQ/USP, 430 p.

POLO EDITORIAL LTDA., 1984. Mercado nacional do norte ao sul do Brasil a laranja. Citrus no 68/69. p. 8-10.

POMPEU JUNIOR, J., 1972. Estudo de comportamento de clones nucelares e velhos de laranjeira Hamlin (Citrus sinensis (L.) Osbeck) em dois porta-enxertos. Campinas, Instituto Agronömico de Campinas, $77 \mathrm{p}$. (Tese).

PRICE, W.C., 1968. Evidence for restriction of a plant virus to phloem cells. Indian Phytopathology 21: 159-166. PRIMO, E。, J • HERNÁNDEZ, Ma , MARTINEZ, P. CUNAT e R. VILA, 1971. Diagnóstico precoz de 1 a tristeza del naranjo. I Separación y reacciones serologicas de particulas nucleoproteicas. Revista de Agroquimica y Tecnologia de Alimen tos. España, 11(2). 
RETUERMA, M.L. e W.C. PRICE, 1972. Evidencia de que el virus tristeza es transmitido por estilete. Boletim Fitos $\underline{a}$ nitario de Za FAO $\underline{20}(5): 111-114$.

RICHARDS, A.V., 1945. Stock-scion influence in citrus. Tropical Agriculturist (Ceylon) 101: 61-ì.

ROISTACHER, C.N., 1976. Tristeza in the Centrol Valley: a warning. California Citrograph 62: 275-279.

ROSSETTI, V., 1947. Porta-enxertos de citrus resistentes a "gomose" de Phytophthora e a "tristeza". Biologico, são Paulo, 13: 89-90.

SALIBE, A.A., 1965. Occurrence of stem pitting in citrus types in Brazil. In: PRICE, W.C. (ed.). Proceedings 3rd International Organization Virologisto, Gainesville p. $40-45$.

SALIBE, A.A., 1969. Curso de especializagão em citricultura a nivel de pós-graduado. Botucatu, FAc. Ciênc. méd. biol. UNESP/Botucatu. 176 p. (mimeografado).

SALIBE, A.A., 1972. Estudo das caracteristicas de algumas ..variedades de lậanja para fins de industrialização. Ciên cia e Cultura, São Paulo, 24(Supl.): 414-5.

SALIBE, A., 1973. The tristeza disease. Fac. de Cienc. med. biol. UNESP/Botucatu, SP, Brasil. 21 p. (mimeografado) 
SALIBE, A.A., 1973. The Tristeza Disease. Proceedings of the First International Citrus Short Course, Gainesville. F1a. p $68-76$.

SALIBE, A.A., 1974. Efeito do porta-enxerto e da localidade no vigor da produção de laranjeiras doce., Citrus sinensis (L.) Osbeck. Botucatu. Fac. Ciênc. Agron., UnESP. 190 p. (Tese de Livre-Docência).

SALIBE, A.A., 1977. The stem pitting effects of tristeza on diferent citrus hosts and their economic significance. Proceedings the International Society of Citriculture, Riverside 3: 953-955.

SALIBE, A.A., 1978. Importāncia do porta-enxerto na citricultura. V. Encontro Nacional de Citricultura, Rio de Ja neiro, PESAGRO-RIO, S.B.F., 14 p.

SALIBE, A.A. e S. MOREIRA, 1968. Porta-enxertos para laranja Barão, Cïtrus sinensis osbeck. Ciēneia e Cultura, são Paulo, 20: 250-251.

SALIBE, A.A. e S. MOREIRA, 1972. Melhoramento do porta-enxerto de laranjeira doce, Citrus sinensis osbeck. Ciência e Cultura, $2 \ddot{4}\left(\mathrm{~S}_{\mathrm{up} 1 .}\right): 425$.

SALIBE, A.A. e S. MOREIRA, 1972. Caracterização da laranja Westin. Ciência e Cultura, São Paulo, 24 (Supl.): 414-5. 
SALIBE, A.A. e S. MOREIRA, 1973. Performance of eight rootstocks with nucellar Baianinha navel orange in sandy soil. Abstracts of International First Citrus Congress, Valencia, p. 225-227.

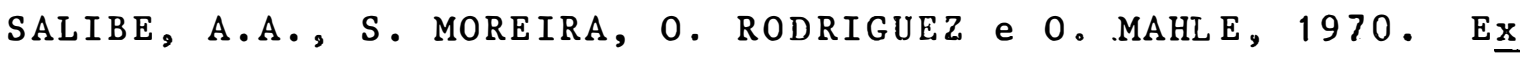
perimentos de "cavalos" para laranja Baianinha Nucelar em solo arenoso. Ciência e Cultura 22: 212.

SALIBE, A.A. e M.M. MISCHAN, 1976. Rootstock effect on tristeza stem pitting expression in sweet orange trees. Proceedings 7th Conference The International Organization of Citrus Virologists Riverside, p. 75-78.

SCHNEIDER, H., 1959. The anatomy of tristeza-virus-infected citrus. In: WALLACE.J.W. (ed.). Citrus Virus Diseases. Berkeley, California p. 73-84.

SCHWARTZ, R.E., 1968. Transmission of the tristeza virus by a leaf union method. S. Afr. I. Agric. Sci. 11: 617$-622$

SILVA, D.M., A.R. OLIVEIRA e E.W. KITAJIMA, 1965. Partial purification of tristeza virus. Proceedings $3 r d$. Conference Interiational organization of Citrus Virologists. Gainesville, p. 10-13.

SNEATH, P.H. e R.R.'SOKAL, 1973. Numerical taxonomy.. The principles and practice of numerical cliassification. W.H. Freeman and Company Ed. Sn. Francisco 573 p. 
STUBBS, L.L., 1964. Transmission and protective inoculation studies with viruses of the citrus tristeza complex. Australian Journal Agricultural Research 15: 752-770.

TEOFILO SOBRINHO, J., 1972. Comportamento da laranjeira-Valēncia (Citrus sinensis $\left(\bar{L}_{\mathrm{e}}\right)$, osbeck) sobre diferentes porta-enxertos. Piracicaba, ESALQ/USP. 67 p. (Tese de Dou torado).

TIMMER, L.W., R. SCORZA, R.F. LEE, 1981. Incidence of tristeza and other citrus diseases in Bolivia. Plant Disease Report 65(6): 515-517.

* TOXOPEUS, H.J., 1937. Stock-sción incompatibility in citrus and its cause. Journal Pomology and Horticultural Science. 14: 360-364.

TSUCHIZAKI, T., A. SASAKI e Y. SAITO, 1978. Purification of citrus tristeza virus from disease citrus fruits and the detection of the virus in citrus tissues by fluorescent antibody techniques. Phytopathology, St. Paul, Minnesota, USA, 68: 139-142.

TUBELIS, A., F.J.L. NASCIMENTO e L.L.FOLONI, 1972。 Meteoro logia e climatologia. Botucatu. Fac. Ciên. Mëd. e Biol. de Botucatu, 3: 344-362 (Mimeografado). 
TUBELIS, A., F.J.L. NASCIMIENTO, L.L. FOLONI, 1971. Parametros climáticos de Botucatu: precipitação e temperatura do ar. In: CONGRESSOS DE ENGENHEIROS E ARQUITETOS DA REGIAO DE BOTUCATU, 1, BOTUCATU. 24 p.

VALIELA, M.V.F., 1948. Informe preliminar acerca de la etio logia de la "podredumbre de los raicillas" del naranjo agrio infestado. Revista de Investigaciones Agricolas, Argentina, $\underline{2}(3): 139-146$

VALIELA, M.V.F., 1951. Tristeza o podredumbre de las raici11 as de los citricos en la Republica Argentina. Ministério de Agricultura e Ganaderia (Buenos Aires) Publ. Rec. n: $1, p .1,63$

VASCONCELLOS, P.W.C., 1939. Estudo comparativo da laranjeira Bahia comun sobre cinco diferentes portamenzertos. In: Secretaria de Agricultura. Boletim de Agricultura São Paulo. p. 597-621.

WALLACE, J.M., 1951. Recent developments on studies of quick decline and related disease. Phytopathology 41: 785-793.

WALLACE, J.M., 1956. La tristeza de los citrus con referencia especial a su situación en los Estados Unidos. Bol. Fit. F.A.O. $4(6): 77-88$. 
WALLACE, J.M., 1968. Tristeza and Seedlings Yellows. In: Indexing Procedures for 15 Virus Diseases of Citrus tree. Agriculture Handbook n! 333, Agricultural Research Service, US. Dep. of Agriculture p. 20-27.

WALLACE, J.M. e H.S.FACETT, 1947. Quick decline of orange trees a virus disease. Science 105:

WALLACE, J.M. e W.P. BITTERS, 1950. The quick decline disease of citrus. Gitrus Leaves, $30(6): 32-37$.

WALLACE, J.M. e R.J. DRAKE, 1972. Use of seedlings-yellows recovery and protection phenomena in producing tristeza tolerant, susceptible, scion-rootstock combination. Proceedings 5th Conference International Organization of Citrus Virologists, Gainesvil1e. p. 137-143.

WALLACE, J.M., 1978. Virus and Viruslike Diseases: The Triste za - Disease Complex. In: REUTHER, W., E.C. CALAVAN e G. E. CARMAN (Eds.). The Citrus Industry IV: 67-173.

WEBBER, H.J., 1943. A doença da "tristeza" do porta-enxerto de laranjeira azeda. O Biologico, SP, 9 : 345-355.

WUTSCHER, H.K., 1977, Citrus tree virus and viruslike diseases. Hortscience 12(5): 16-22.

ZEMAN, V., 193.1. Una enfermedad nueva en los naranjales de Corrientes. Argentina. Physis 19: 410-411. 
.119.

APENDICE 
TABELA 13. Principais caracteristicas quimicas do solo da ärea Lajeado.

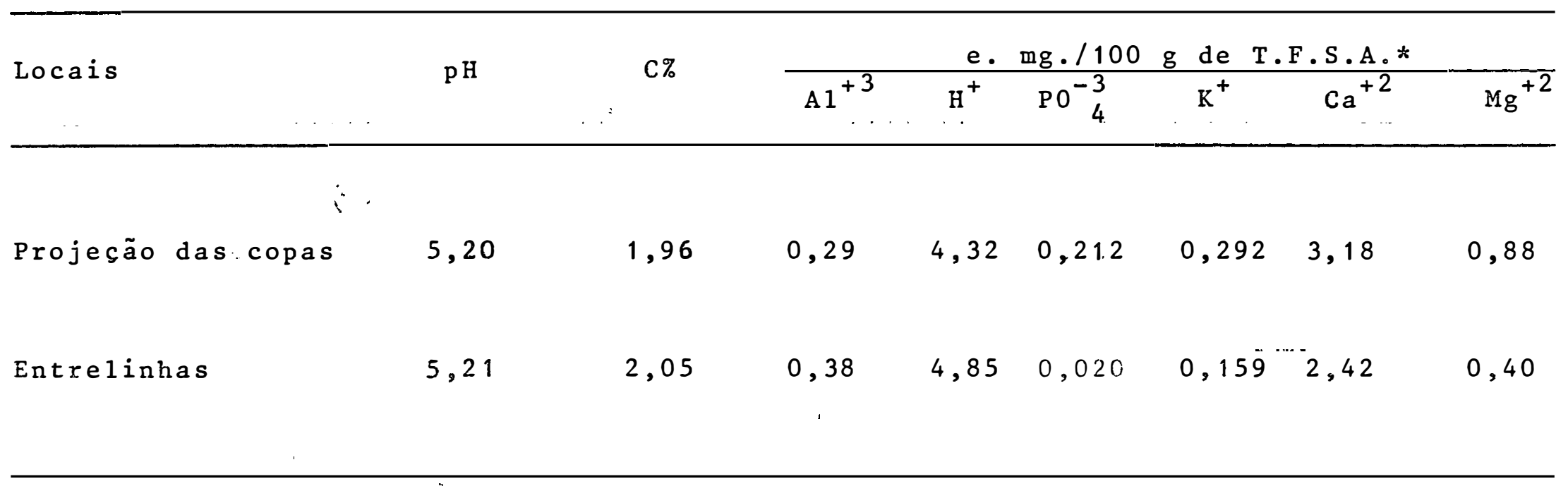

* Terra Fina Seca ao Ar

Fonte: SALIBE: (1974) 
.121.

TABELA 14. Totais de precipitação pluviométrica (mm) e média de temperatura mensal $\left({ }^{\circ} \mathrm{C}\right)$, ocorridos nos perio dos de junho a dezembro de 1982 e janeiro a dezem bro de 1983, na àrea de Lajeado, UNESP/Botucatu. SP .

\begin{tabular}{|c|c|c|c|c|c|}
\hline Anos & Meses & $\begin{array}{r}\text { Precipitação } \\
\text { total }\end{array}$ & $\begin{array}{l}\text { pluviométrica } \\
(\mathrm{mm})\end{array}$ & $\begin{array}{l}\text { Temp } \\
\text { Média }\end{array}$ & Mensal $1{ }^{\circ} \mathrm{C}$ \\
\hline \multirow[t]{7}{*}{1982} & Junho & 224,0 & & & 18,3 \\
\hline & Julho & 29,6 & & & 17,9 \\
\hline & Agosto & 21,5 & & & 19,5 \\
\hline & Setembro & 20,0 & & & 20,1 \\
\hline & Outubro & 179,9 & & & $' 21,2$ \\
\hline & Novembro & 315,5 & & & 22,4 \\
\hline & Dez embro & 294,5 & & & 21,5 \\
\hline \multirow[t]{3}{*}{1983} & Janeiro & 391,8 & & & 22,4 \\
\hline & Fevereiro & 276,3 & & & 23,1 \\
\hline & Março & 214,0 & & & 21,4 \\
\hline \multirow[t]{9}{*}{$:$} & Abril & 113,8 & 8 & $\cdot$ & 20,7 \\
\hline & Maio & 286,4 & & & 19,2 \\
\hline & Junho & 222,4 & & & 16,3 \\
\hline & Julho & 21,6 & & & 18,3 \\
\hline & Agosto & 0,0 & & & 28,6 \\
\hline & Setembro & 216,5 & & & 16,5 \\
\hline & Outubro & 116,7 & & & 19,5 \\
\hline & Novembro & 141,5 & & & 22,0 \\
\hline & Dezembro & 245,2 & & & 21,8 \\
\hline
\end{tabular}


TABELA 15. Delineamento do pomar experimental na área de Lajeado, Est. Exp. Presidente Médici, UNESP, Botucatu, SP.

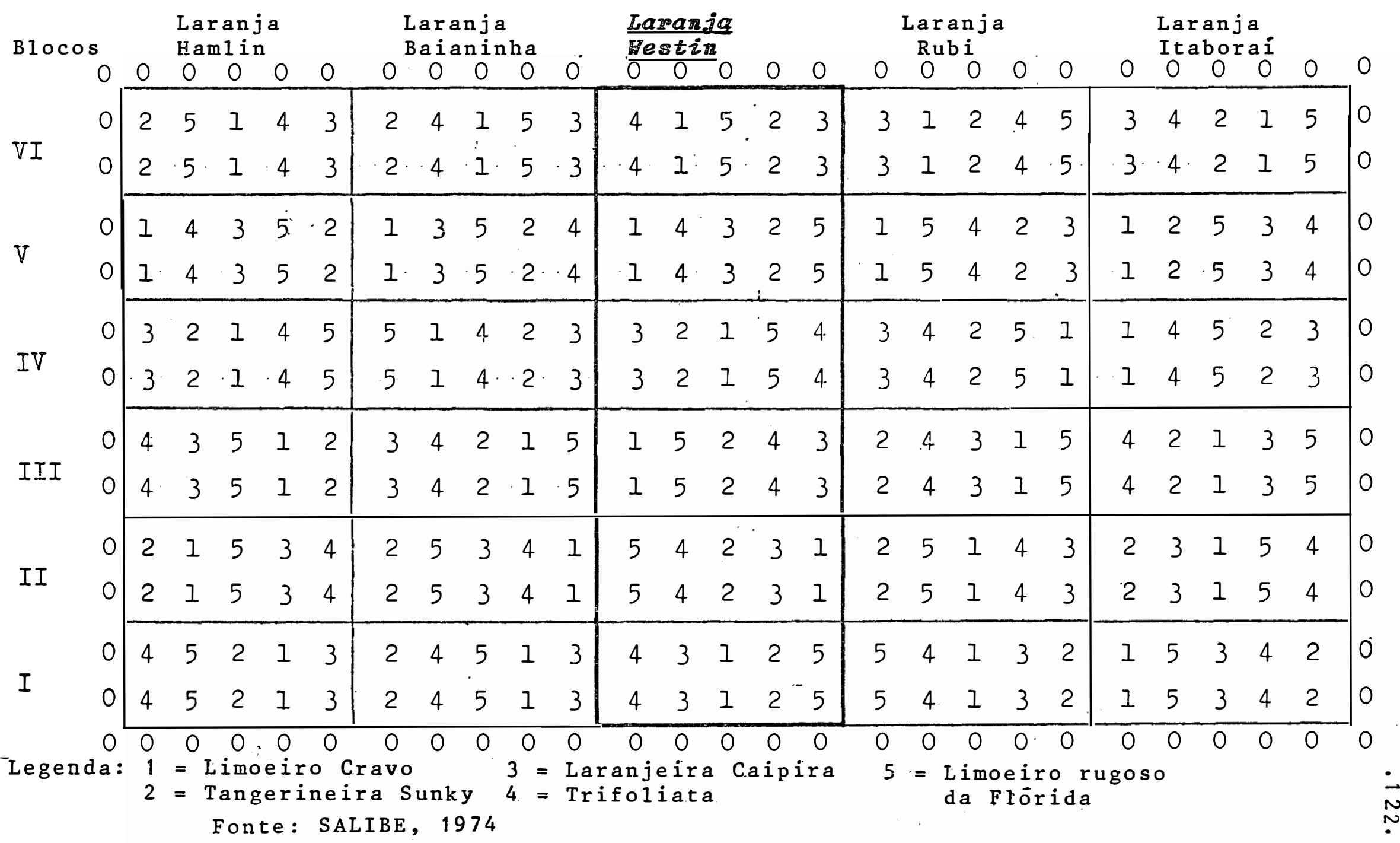


TABELA 16. Totais de precipitação pluviométíica (mm) e média de temperatura mensal $\left({ }^{\circ} \mathrm{C}\right)$ ocorridos nos periodos de junho a dezembro de 1982 e janeiro a dezembro de 1983, na ärea da ESALQ-USP, Piracicaba, SP.

\begin{tabular}{|c|c|c|c|c|}
\hline Anos & Meses & $\begin{array}{c}\text { Precipitação pluviométrica } \\
\text { total (mm) }\end{array}$ & $\begin{array}{l}\text { Temp } \\
\text { Média }\end{array}$ & $\begin{array}{l}\text { peratura } \\
\text { Ṁensal }{ }^{\circ} \mathrm{C}\end{array}$ \\
\hline \multirow[t]{7}{*}{1982} & Junho & 162,7 & & 19,3 \\
\hline & Julho & 21,7 & & 18,8 \\
\hline & Agosto & 44,7 & & 19,5 \\
\hline & Setembro & 8,1 & & 20,8 \\
\hline & Outubro & 254,5 & & 22,2 \\
\hline & Novembro & 210,2 & & 24,5 \\
\hline & Dezembro & 215,0 & & 23,1 \\
\hline \multirow[t]{4}{*}{1983} & Janeiro & 207,5 & & 24,5 \\
\hline & Fevereiro & 283,9 & & 24,8 \\
\hline & Maroo & 225,6 & & 23,3 \\
\hline & Abril & 189,5 & & 22,1 \\
\hline \multirow{4}{*}{$\vdots$} & Maio & 234,7 & & 21,2 \\
\hline & Junho & 174,0 & & 18,1 \\
\hline & Ju 1 ho & 24,0 & & 18,9 \\
\hline & Agos to & 2,2 & & 18,9 \\
\hline \multirow[t]{4}{*}{ v } & Setembro & 197,4 & & 18,9 \\
\hline & Outubro & 129,1 & & 21,8 \\
\hline & Novembro & 88,4 & & 23,1 \\
\hline & Dezembro & 161,4 & & 24,1 \\
\hline
\end{tabular}

Fonte: Departamento de Fisica e Meteorologia, ESALQ/USP, Piracicaba, SP, 
.124.
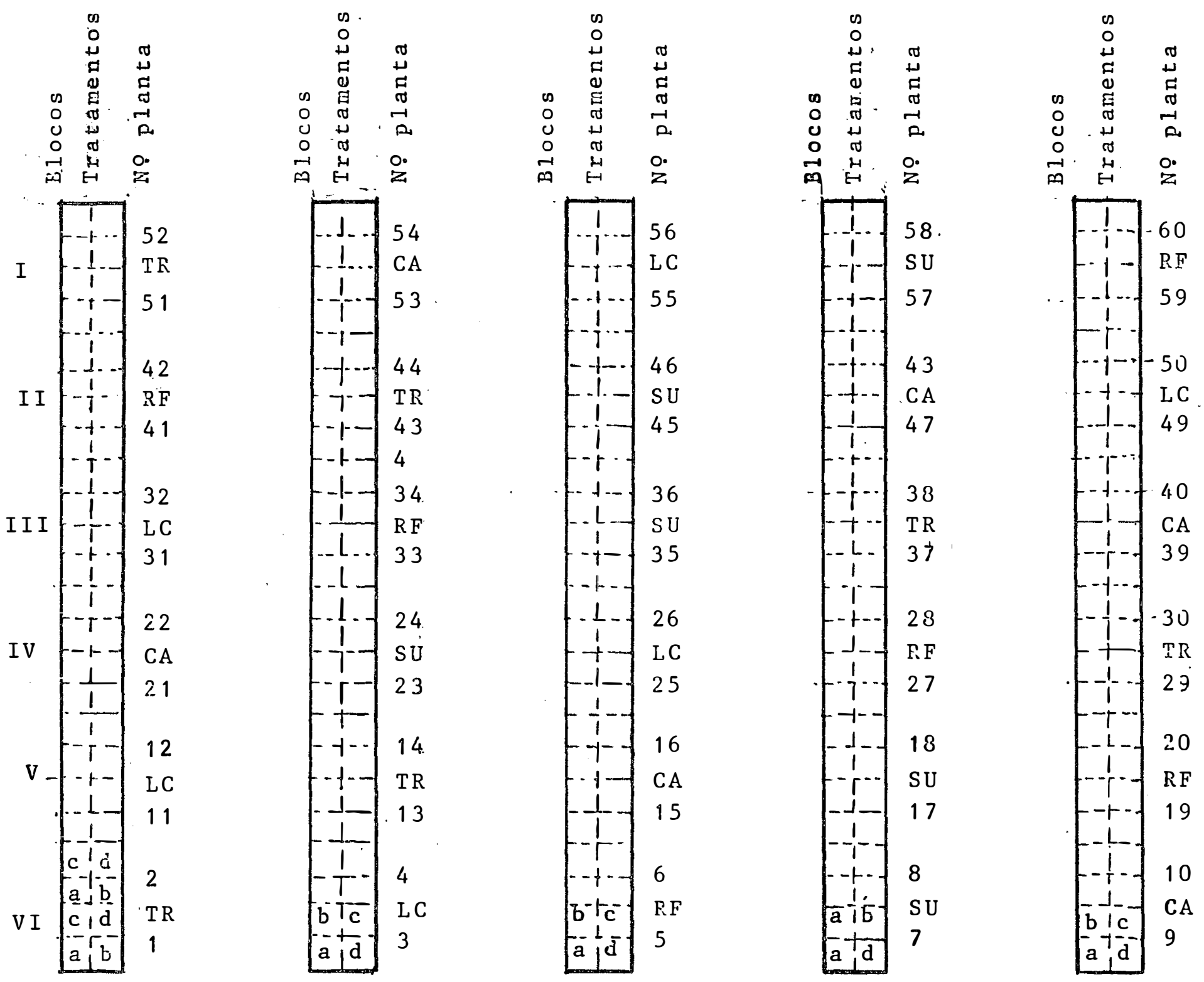

TABELA 17.. Delineamento do viveiro experimental de limoeiro Galego (Citrus aurantifolia Swo $_{0}$ ) para indexaço do virus da tristeza em copas de laranjeira 'Westin' sobre cinco porta-enxertos. ESALQ-USP, Piracicaba, SP. Julho'de 1982 . 
.125.

TABELA 18. Leitura de "stem pitting" ou caneluras em plantas teste de Limão Galego, no viveiro experimental da ESALQ-USP, Piracicaba, SP, em 1984 .

\begin{tabular}{|c|c|c|c|c|c|c|c|}
\hline \multirow{2}{*}{$\begin{array}{l}\text { Trat。 } \\
\text { P.E. }\end{array}$} & \multicolumn{6}{|c|}{ Blocos } & \multirow{2}{*}{ Totais } \\
\hline & 1 & 2 & 3 & 4 & 5 & 6 & \\
\hline $\mathrm{LW} / \mathrm{CA}$ & 4,125 & 4,125 & 4,625 & 4,125 & 3,500 & 4,000 & 24,50 \\
\hline $\mathrm{LW} / \mathrm{RF}$ & 4,650 & 3,375 & 4,00 & 4,50 & 4,875 & 4,25 & 25,65 \\
\hline LW / S U & 3,25 & 4,50 & 3,75 & 3,625 & 4,125 & 3,875 & 23,13 \\
\hline $\mathrm{LW} / \mathrm{LC}$ & 4,00 & 3,875 & 3,125 & 4,500 & 3,375 & 4,25 & 23,13 \\
\hline $\mathrm{LW} / \mathrm{TR}$ & 4,25 & 3,500 & 3,375 & 3,625 & 3,625 & 3,50 & 21,88 \\
\hline Totais & 20,28 & 19,38 & 18,88 & 20,38 & 19,50 & 19,88 & 118,30 \\
\hline
\end{tabular}


.126 .

TABELA 19. Leitura média de sintomas em folhas das plantas teste de Limão Galego, na ESALQ-USP, Piracicaba,em 1984.

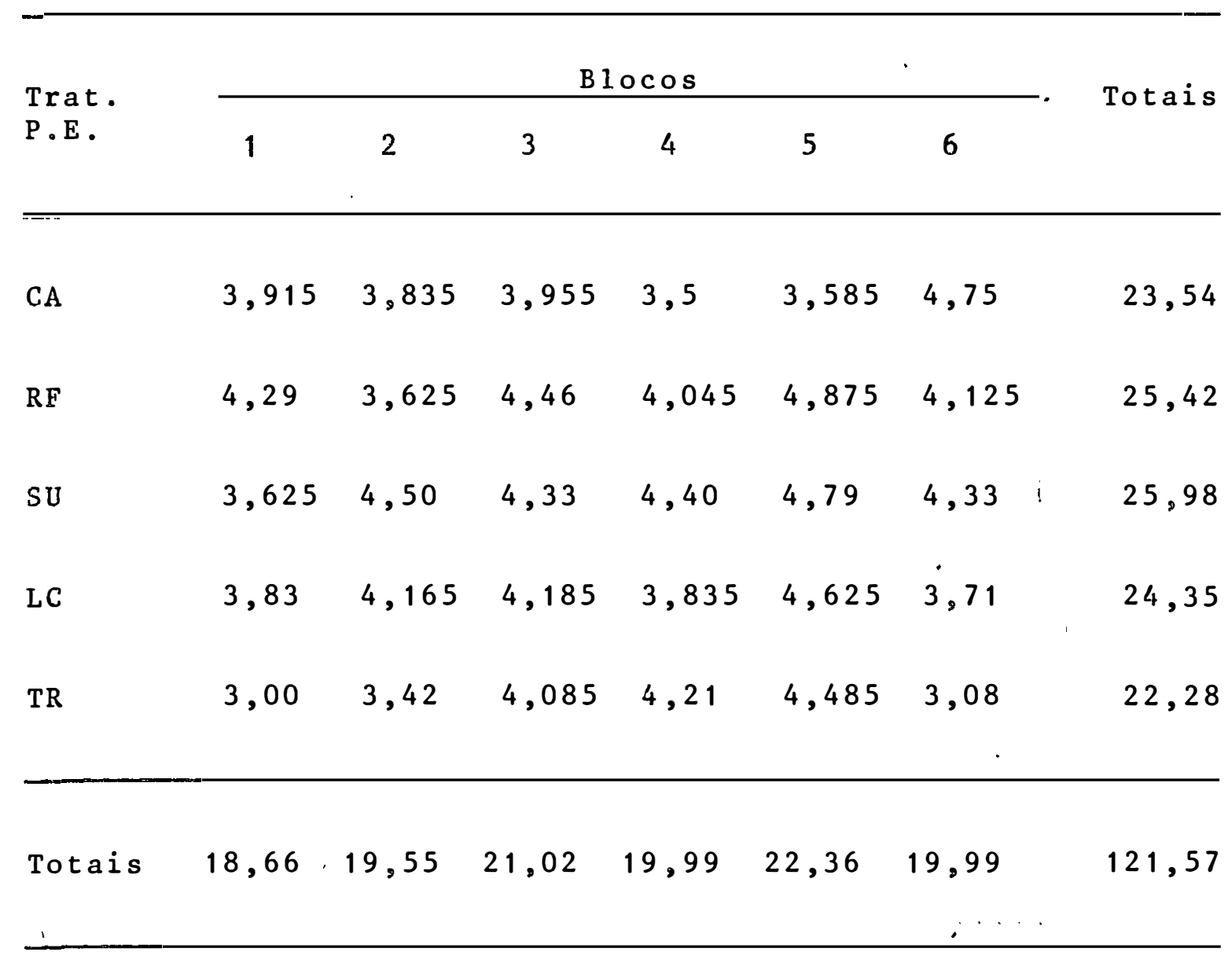


.127.

a) Sintaras de "stem pirting" ou cadeluras ed pladtas reste limáo Golego

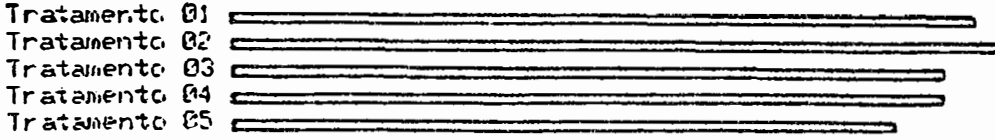

FIGURA 19. Representação gräfica em barras de notas médias da avaliação de sintomas de tristeza da laranjeira

'Westin' sobre cinco porta-enxertos. ESALQ-USP,P racicaba, SP. Fevereiro, 1984. 
.128 .

TABELA 20. Leitura de "stem pitting" ou caneluras em ramos da copa das laranjeiras 'Westin', na E.E. Presidente Médici - UNPES, Botucatu, SP, em 1984 .

Trat.

Blocos

P.E.

\begin{tabular}{llllll}
\multicolumn{9}{c}{ B Bocos } & \\
\hline 1 & 2 & 3 & 4 & 5 & 6
\end{tabular} Totais

CA

1,225

1,250

$1,075 \quad 1,150$

$0,700 \quad 0,800$.

6,200

R F

1,350

$0,850 \quad 1,100$

1,050

1,250

1,050

6,650

SU

$1,000 \quad 0,825$

0,500

0,700

$0,700 \quad 0,650$

4,375

I. C

$0,575 \quad 0,725$

0,750

0,725

0,700

0,350

3,825

TR

1,32

1,625

2,125

1,275

1,650

0,800

8,800

Totais

$$
5,475
$$

$$
5,275
$$

5,550

4,900

$5,000 \quad 3,650$

29,85 
.129 .

TABELA 21. Circunferência média ( $\mathrm{cm}$ ) do tronco da laranjeira 'Westin', sobre os diferentes porta-enxertos na E.E. "Presidente Médici", Botucatu, SP, em 1984.

Trat.

P.E.

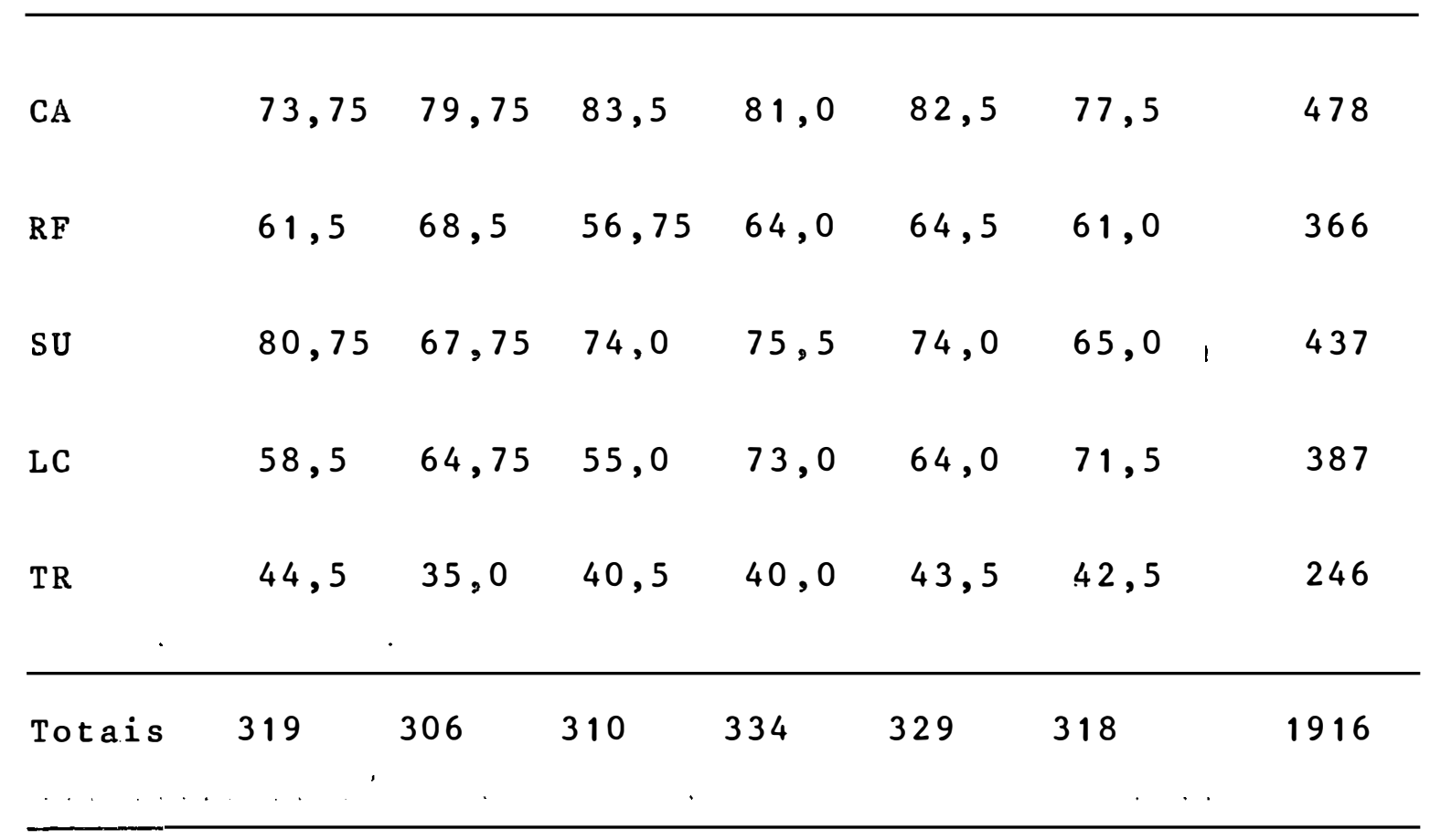

\section{B locos}

$\begin{array}{lllllll}1 & 2 & 3 & 4 & 5 & 6\end{array}$


TABELA 22. Diâmetro médio (m) da copa da laranjeira 'Westin', sobre os diferentes porta-enxertos, na E.E. "Presidente Médici", Botucatu, SP, em 1984.

\begin{tabular}{|c|c|c|c|c|c|c|c|}
\hline \multirow{2}{*}{$\begin{array}{l}\text { Trat. } \\
\text { P.E. }\end{array}$} & \multicolumn{6}{|c|}{ Blocos } & \multirow[t]{2}{*}{ Totais } \\
\hline & 1 & 2 & 3 & 4 & 5 & 6 & \\
\hline $\mathrm{CA}$ & 5,12 & 4,93 & 5,13 & 5,18 & 5,55 & 5,38 & 31,3 \\
\hline$R F$ & 4,95 & 4,78 & 4,70 & 4,53 & 5,53 & 4,98 & 29,47 \\
\hline SU & 4,93 & 4,73 & 4,60 & 5,13 & 5,18 & 4,70 & 29,27 \\
\hline LC. & 4,63 & 4,60 & 4,45 & 5,01 & 5,05 & 5,43 & 29,17 \\
\hline $\mathrm{TR}$ & 4,40 & 4,08 & 3,75 & 3,93 & 4,85 & 4,70 & 25,71 \\
\hline Totais & 24,04 & 23,12 & 22,63 & 23,78 & 26,16 & 25,19 & 144,92 \\
\hline
\end{tabular}


TABELA 23. Altura média (m) das plantas de laranjeira 'Westin' sobre os diferentes porta-enxertos, em E.E. Presidente Médici - UNESP, Botucatu, SP, em 1984.

Trat.

P.E.

\begin{tabular}{lllllll}
\multicolumn{1}{l}{ Blocos } & & Totais \\
\hline 1 & 2 & 3 & 4 & 5 & 6
\end{tabular}

CA

4,63

4,75

4,75

4,88

4,63

4,63

28,27

RF

$$
4,00
$$

4,00

3,50

3,63

4,13

4,25

23,51

SU

$4,634,88$

4,50

4,63

4,63

4,00

27,27

IC

$3,88 \quad 4,00$

3,63

4,63

4,38

4,25

24,77

TR

$$
3,25
$$

3,38

4,25

3,50

3,50

21,26

$$
20,39
$$

22,02
21,2

\section{0,63}

125,1 
TABELA 24. Area produtiva média $\left(\mathrm{m}^{2}\right)$ da laranjeira 'Westin' sobre os diferentes porta-enxertos, em 1984 .

\begin{tabular}{|c|c|c|c|c|c|c|c|}
\hline \multirow{2}{*}{$\begin{array}{l}\text { Trat. } \\
\text { P.E. }\end{array}$} & \multicolumn{6}{|c|}{ Blocos } & \multirow{2}{*}{ Totais } \\
\hline & 1 & 2 & 3 & 4 & 5 & 6 & \\
\hline $\mathrm{CA}$ & 54,52 & 53,22 & 55,71 & 57,65 & 59,78 & 57,63 & 339 \\
\hline $\mathrm{RF}$ & 46,33 & 44,46 & 39,14 & 38,54 & 54,29 & 49,04 & 272 \\
\hline sU & 52,03 & 51,97 & 46,95 & 54,52 & 55,14 & $\begin{array}{c}43,59 \\
1\end{array}$ & 304 \\
\hline LC & 41,76 & 42,49 & 37,73 & 53,05 & 51,11 & 53,76 & 280 \\
\hline$T R$ & 34,08 & 32,12 & 29,10 & 37,39 & 40,67 & 39,14 & 213 \\
\hline Totais & 229 & 224 & 209 & 241 & 261 & 244 & 1408 \\
\hline$\cdots$ & $\therefore$ & & & & & . & \\
\hline
\end{tabular}


.133.

TABELA 25. Indice de conformação (A/D) das laranjeiras 'Westin' sobre os diferentes porta-enxertos.

\begin{tabular}{|c|c|c|c|c|c|c|c|}
\hline \multirow{2}{*}{$\begin{array}{l}\text { Trat. } \\
\text { P.E. }\end{array}$} & \multicolumn{6}{|c|}{ Blocos } & \multirow{2}{*}{ Totais } \\
\hline & 1 & 2 & 3 & 4 & 5 & 6 & \\
\hline $\mathrm{CA}$ & 0,903 & 0,963 & 0,926 & 0,942 & 0,834 & 0,861 & 5,429 \\
\hline $\mathrm{RF}$ & 0,808 & 0,837 & 0,745 & 0,801 & 0,747 & 0,853 & 4,791 \\
\hline \multirow[t]{2}{*}{ SU } & 0,939 & 1,032 & 0,978 & 0,903 & 0,894 & 0,851 & 5,597 \\
\hline & & & & & \multicolumn{3}{|c|}{$!$} \\
\hline $\mathrm{LC}$ & 0,838 & 0,869 & 0,816 & 0,924 & 0,867 & 0,783 & 5,097 \\
\hline $\mathrm{TR}$ & 0,739 & 0,828 & 0,901 & 1,081 & 0,722 & 0,745 & 5,016 \\
\hline \multirow[t]{2}{*}{ Totais } & 4,227 & 4,527 & 4,366 & 4,651 & 4,064 & 4,093 & 25,93 \\
\hline & .. & & & & & & \\
\hline
\end{tabular}


1) Circunferëncio do rronco (c口)

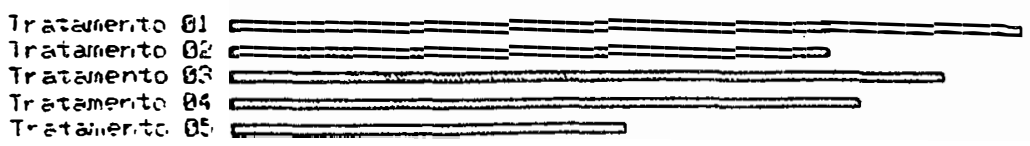

2) Diädiezio do copa (m)

Trat sllierotio (i)

Tratelueriti $0^{\circ}$

Tratasuerit: 0?

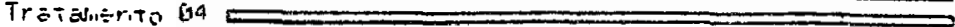

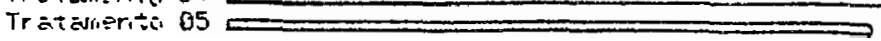

3) Altura da planta (m)

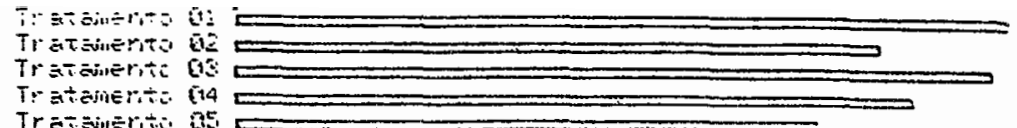

(1)

4) Area produtiva (at ${ }^{2}$;

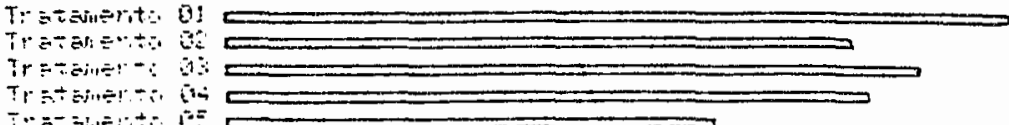

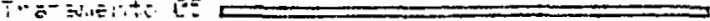

s) Indice de cuntormacaio $($ í/D)

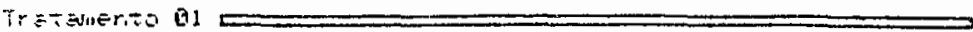

Traisner.te $0 \mathrm{O}$

Tratjneriti $80 \mathrm{CO}$

Tr $\equiv$ Tavierito 014

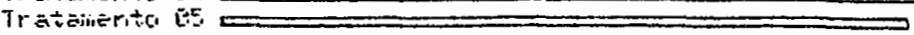

Tratamento 01 a Laranja Caipira (Citrus sincnsis (L.) osbeck]

Iracamenco 02 a Limac hugoso da Flórido (Celrus iamblicri Lush)

Irazamento 03 . Iangerina Sunky (Cixnus dunty Nortex Tanaka)

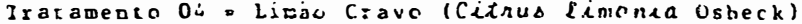

Tratamento OS = la:anja $t: 2$ foliata (Fonclias licholeata Raff)

FIGURA 20. Representação gräfica em barras das médias dos valores do desenvolvimento e vigor da laranjeira

'Westin' sobre cinco porta-enxertos. ESALQ-USP,P

racicaba. Fevereiro, 1984. 
.135.

TABELA 26. Produção média (1969-1974 em kg/parcela) da laranjeira 'Westin' sobre os diferentes porta-enxertos, na E.E. Presidente Médici - UNESP, Botucatu, SP.

Trat.

B locos

Totais

P.E.

\begin{tabular}{lllllll}
\hline 1 & 2 & 3 & 4 & 5 & 6
\end{tabular}

CA

$48,83 \quad 50,83 \quad 62,66 \quad 55,66 \quad 48,00 \quad 55,16 \quad 321,1$

RF

$64,3355,00$

55,83

53,00

56,16

$62,5^{!} \quad 346,8$

SU

$64,00 \quad 90,66$

59,33

68,83

90,33

70,16

443,3

LC

71,66

90,16

75,33

84,16

84,00

92,00

497,3

TR

62,00

72,33

54,16

55,00

53,16

60,50

357,2

!

Totais

$310,8 \quad 358,0$

307,3

316,

331 ,

340,3

1966 
.136.

TABEla 27. Produção mèdia de 3 anos (1980-82), em nümero de caixas/parcela, das laranjeiras 'Westin' sobre os diferentes porta-enxertos, na E.E. Presidente Médici - UNESP, Botucatu, SP.

\begin{tabular}{|c|c|c|c|c|c|c|c|}
\hline \multirow{2}{*}{$\begin{array}{l}\text { Trat. } \\
\text { P.E. }\end{array}$} & \multicolumn{6}{|c|}{ Blocos } & \multirow[t]{2}{*}{ Totais } \\
\hline & 1 & 2 & 3 & 4 & 5 & 6 & \\
\hline $\mathrm{CA}$ & 7,42 & 11,17 & 10,75 & 8,71 & 8,58 & 6,17 & 52,8 \\
\hline $\mathrm{RF}$ & 8,33 & 7,29 & 7,17 & 5,33 & 7,63 & 6,00 & 41,8 \\
\hline SU & 9,42 & 10,17 & 9,00 & 12,50 & 9,25 & $6,25^{!}$ & 56,6 \\
\hline LC & 6,75 & 9,33 & 3,79 & 8,25 & 5,58 & 6,67 & 40,4 \\
\hline $\mathrm{TR}$ & 5,21 & 4,96 & 4,75 & 5,71 & 6,58 & 3,13 & 30,3 \\
\hline Totais & 37,1 & 42,9 & 35,5 & 40,5 & 37,6 & 28,2 & 221,9 \\
\hline
\end{tabular}


.137.

TABELA 28. Produção mëdia de 3 anos (1980-82), em número de frutos/parcela, das laranjeiras 'Westin' sobre os diferentes porta-enxertos, na E.E. Presidente Medici - UNESP, Botucatu, SP.

\begin{tabular}{|c|c|c|c|c|c|c|c|}
\hline \multirow{2}{*}{$\begin{array}{l}\text { Trat. } \\
\text { P.E. }\end{array}$} & \multicolumn{6}{|c|}{ Blocos } & \multirow{2}{*}{ Totais } \\
\hline & 1 & 2 & 3 & 4 & 5 & 6 & \\
\hline $\mathrm{CA}$ & 1340 & 2008 & 1928 & 1580 & 1567 & 1108 & 9531 \\
\hline \multirow[t]{2}{*}{$\mathrm{RF}$} & 1388 & 1219 & 1193 & 888 & 1269 & 998 & 6955 \\
\hline & & & & & & \multicolumn{2}{|c|}{$!$} \\
\hline$S U$ & 1661 & 1790 & 1587 & 2205 & 1628 & 1104 & 9975 \\
\hline LC C & 1205 & 1661 & 670 & 1469 & 990 & 1184 & 7179 \\
\hline TR & 1001 & 959 & 922 & 1104 & 1272 & 603 & 5861 \\
\hline Totais & 6595 & 7637 & 6300 & 7246 & 6726 & 4997 & 39501 \\
\hline$\therefore$ & & & & & & . & \\
\hline
\end{tabular}


.138.

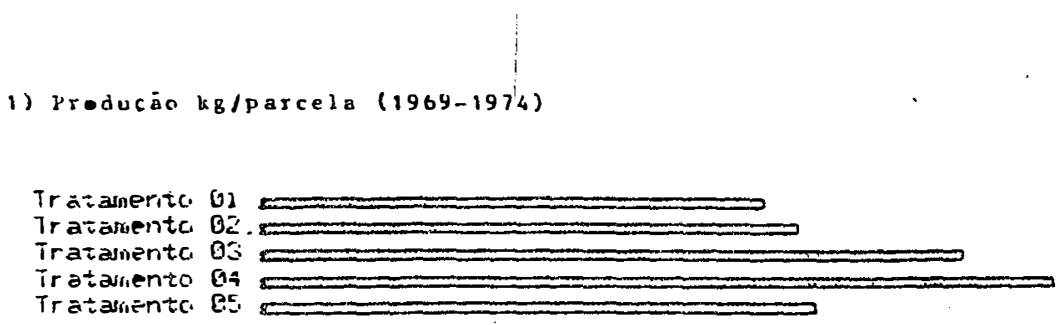

2) Di de frutos/parcela $(9980-1982)$

Tratanentc. $\mathrm{Bi}_{\mathrm{i}} \mathrm{CO}$

Tratanentc. $0_{c}=0=0$

Trätauento oj $\longrightarrow$

Traicthento 014

Traidiento Qe

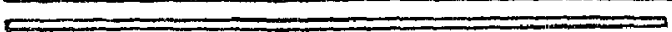

3) DQ de caixas/parcela (1980-1982)

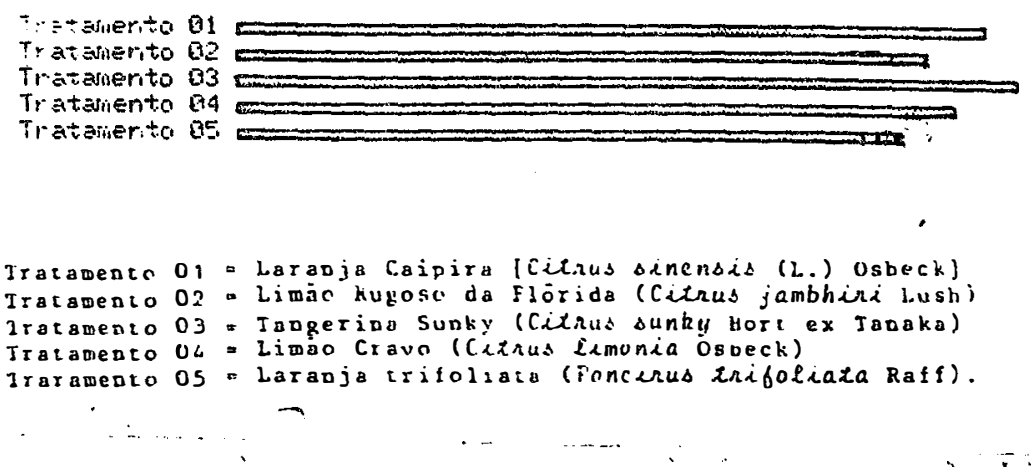

FIGURA 21. Representạạão grä́fica em barras dos vàlóres médios dos paràmetros de procução da laranjeira 'Westin . sobre cinco porta-enxertos. ESALG-USP, Piracicaba, SP. Fevereiro, 1984 . 